\title{
Developments in the chemistry of the hard early metals (Groups 1-6) with thioether, selenoether and telluroether ligands
}

\author{
Yao-Pang Chang, William Levason and Gillian Reid* \\ School of Chemistry, University of Southampton, Southampton SO17 1BJ, UK
}

Received:

\begin{abstract}
The coordination chemistry of neutral thio-, seleno- and telluroether ligands towards the hard s-block, f-block and higher oxidation state early d-block metals has developed significantly over the 15 or so years. This has revealed several hitherto unknown classes of complexes and new insights into the chemistries of these hard-soft metal-ligand combinations. This Perspective describes the synthetic routes used to access such complexes and draws out their key structural features and spectroscopic properties. Where appropriate, applications of these species are also highlighted, including their use as single source precursors for the chemical vapour deposition of semiconducting metal chalcogenide thin films and as pre-catalysts for olefin polymerisation reactions.
\end{abstract}

\section{Introduction}

Thioether and selenoether ligands, which are neutral sulfur and selenium donors respectively, were for many years viewed as modest $\sigma$-donor ligands that formed complexes with the softer later d-block elements in low or medium oxidation states, or with post transition metals such as silver or mercury. ${ }^{1,2}$ Complexes of the early d-block metals were mostly limited to low valent organometallics or carbonyls. The chemistry of telluroethers was very little explored, in major part a reflection of their limited availability and, for the alkyl telluroethers in particular, their extremely malodorous nature. ${ }^{2,3}$ The $\mathrm{R}_{2} \mathrm{Te}$ ligands are also oxygen sensitive (in contrast to the air stable $\mathrm{R}_{2} \mathrm{~S}$ or $\mathrm{R}_{2} \mathrm{Se}$ ), modest reducing agents and prone to cleavage of the $\mathrm{C}-\mathrm{Te}$ bond upon reaction with some metal centres. Even today, their chemistry remains much less extensive than that of their lighter analogues. ${ }^{4}$ Major developments in the syntheses and coordination chemistry of macrocyclic thioethers considerably extended the range and stability of complexes containing metal centres across the d-block. ${ }^{5,6}$ Subsequently, similar, but more limited, macrocyclic selenoether examples were obtained. ${ }^{4}$ Telluroether macrocycles remain largely unknown, although a few mixed donor $(\mathrm{S} / \mathrm{Te}, \mathrm{O} / \mathrm{Te}, \mathrm{N} / \mathrm{Te})$ examples have been obtained. ${ }^{7}$ In contrast, a significant range of $\mathrm{O} / \mathrm{S}, \mathrm{O} / \mathrm{Se}$ heterocrown complexes have been described in the last 20 years, and have provided a rich chemistry, again, mostly with the later d-block and p-block elements. ${ }^{7}$ More recent work has resulted in complexes of chalcogenoethers with many of the p-block elements, 
although these are often of limited stability, typically labile in solution and the chalcogenoether ligands are displaced by strong donor solvents. ${ }^{8,9}$

Based upon the characteristic chemistry of neutral S, Se or Te donor ligands outlined above, it would seem that their complexes with hard metal centres of the s- or f- blocks or of the early d-block metals in medium or high oxidation states, would be extremely unstable or often unobtainable. Our 2002 review of the known chemistry of the early transition metals with macrocyclic or polydentate thio- and seleno-ethers ${ }^{10}$ described a small number of complexes in oxidation states $(\geq 3)$, many unstable to air or moisture, and noted there were no examples with the s-block elements, Sc or Y, and only a handful of examples with the f-block ions. However, more recent research has shown that this was a very incomplete picture of the chemistry of these ligands, and that whilst many of the complexes are of limited stability and decomposed by strong donor solvents or moisture, a surprisingly wide range of examples have now been characterised with the s-, f- and early d-block metals. In addition to their inherent interest from a ligand point of view, they also often provide the metal centre in unusual electronic environments, significantly extending the chemical behaviour of the latter. The key to successful synthesis of complexes in this area is the careful design of metal reagents and choice of solvents and reaction conditions to avoid complexation of the metal by stronger/harder donor including, in some systems, competing anion coordination. In terms of characterisation techniques in this area of chemistry, X-ray crystallography is essential given the sensitivity and lability of many of the complexes of the hard metal ions. In addition, multinuclear NMR spectroscopy can provide important insights into the metal-chalcogen interactions, although is somewhat limited by the ligand dissociation processes and or fast exchange in solution. The major NMR properties relevant to this article are in Table 1.

In this Dalton Perspective we review the coordination chemistry of the s-block, f-block and the early d-block metals in higher oxidation states with neutral thio-, seleno- and telluro-ether ligands. Low and medium oxidation state complexes, organometallics or carbonyls, which have very different chemistries, are excluded. We have also included neutral hybrid ligands such as heterocrowns (Scheme 1) or N/S-donor pincers where appropriate, but exclude anionic chalcogenides and chalcogenolates, as well as charged anionic bi- or polydentate ligands containing neutral chalcogenoether donor groups. Literature coverage focuses on work since 2000 , but earlier work is included in cases where either no more recent reports exist, or it is needed for context. Coverage is intended to illustrate the scope and characteristics of the chemistry in this area, together with their applications, rather than to provide an exhaustive listing of all examples, although we aim to provide a balanced coverage of published work.

The synthesis of the various ligands and overviews of their typical coordination modes have been described elsewhere. ${ }^{3-7,11,12}$ The surveys of the coordination chemistry of these elements in Comprehensive Coordination Chemistry II, ${ }^{13}$ provide the context for the chalcogenoether complexes containing lower oxidation states of the early d-block metals. 


\section{Abbreviations for ligands.}

15-crown-5 $=1,4,7,10,13$-pentaoxacyclopentadecane

18-crown-6 = 1,4,7,10,13,16-hexaoxacyclooctadecane

[9] $\mathrm{aneS}_{3}=$ 1,4,7-trithiacyclononane

$[10] \mathrm{aneS}_{3}=1,4,7$-trithiacyclodecane

[11] $\mathrm{aneS}_{3}=1,4,8$-trithiacycloundecane

$[12] \mathrm{aneS}_{3}=1,5,9$-trithiacyclododecane

ttob $=2,5,8$-trithia[9]-o-benzophane

[12] $\mathrm{aneS}_{4}=1,4,7,10$-tetrathiacyclododecane

[14] $\mathrm{aneS}_{4}=1,4,8,11$-tetrathiacyclotetradecane

[15]aneS $S_{5}=1,4,7,10,13$-pentathiacyclopentadecane

$[18] \mathrm{aneS}_{6}=1,4,7,10,13,16$-hexathiacyclooctadecane

[16] $\mathrm{ane}_{4}=1,5,9,13$-tetrathiacyclohexadecane

[24]ane $\mathrm{S}_{8}=1,4,7,10,13,16,19,22$-octathiacyclotetracosane

$\mathrm{Me}_{2}[9] \mathrm{aneN}_{2} \mathrm{~S}=$ 1,4-dimethyl-1,4-diaza-7-thiacyclononane

[9] $\mathrm{aneN}_{2} \mathrm{~S}=1,4$-diaza-7-thiacyclononane

[9] $\mathrm{aneOS}_{2}=1$-oxa-4,7-dithiacyclononane

[15]ane ${ }_{3} \mathrm{~S}_{2}=1,4,7$-trioxa-10,13-dithiacyclopentadecane

[18] $\mathrm{aneO}_{3} \mathrm{~S}_{3}=1,4,7$-trioxa-10,13,16-trithiacyclooctadecane

[18] ane ${ }_{5} \mathrm{~S}=1,4,7,10,13$-pentaoxa-16-thiacyclooctadecane

[18] aneO ${ }_{4} \mathrm{~S}_{2}=1,4,10,13$-tetraoxa-7,16-dithiacyclooctadecane

Iso-[18] $\mathrm{aneO}_{4} \mathrm{~S}_{2}=1,4,7,13$-tetraoxa-10,16-dithiacyclooctadecane

[18] $\mathrm{aneO}_{2} \mathrm{~S}_{4}=1,10$-dioxa-4,7,13,16-tetrathiacyclooctadecane

[16] $\mathrm{aneSe}_{4}=1,5,9,13$-tetraselenacyclohexadecane

$[12] \mathrm{aneSe}_{3}=1,5,9$-triselenacyclododecane

[18] $\mathrm{aneO}_{4} \mathrm{Se}_{2}=1,4,10,13$-tetraoxa-7,16-diselenacyclooctadecane, $\mathrm{mnS}_{2} \mathrm{O}_{5}=$ malenitrile-dithio[21]crown-7

[18] $\mathrm{aneO}_{4} \mathrm{Te}_{2}=1,4,10,13$-tetraoxa-7,16-ditelluracyclooctadecane

$[\mathrm{BAr}]^{-}=\left[\mathrm{B}\left\{3,5-\left(\mathrm{CF}_{3}\right)_{2} \mathrm{C}_{6} \mathrm{H}_{3}\right\}_{4}\right]^{-}$

thf $=$ tetrahydrofuran

tht $=$ tetrahydrothiophene 
Table 1: Nuclear properties of the metals and donor atoms relevant to the work in this Perspective $^{\text {a }}$

\begin{tabular}{|c|c|c|c|c|c|}
\hline Nucleus & I & $\begin{array}{c}\text { Natural } \\
\text { abundance } \\
\%\end{array}$ & $\begin{array}{c}\mathrm{Q} \\
\times 10^{-28} \mathrm{~m}^{2}\end{array}$ & $\begin{array}{c}\Xi \\
\mathrm{MHz}\end{array}$ & $\begin{array}{c}\mathrm{Rc} \\
\text { (receptivity relative to }{ }^{13} \mathrm{C} \text { ) }\end{array}$ \\
\hline${ }^{7} \mathrm{Li}$ & $3 / 2$ & 92.6 & $-3.7 \times 10^{-2}$ & 38.87 & $1.54 \times 10^{3}$ \\
\hline${ }^{23} \mathrm{Na}$ & $3 / 2$ & 100 & 0.10 & 26.43 & $5.24 \times 10^{2}$ \\
\hline${ }^{39} \mathrm{~K}$ & $3 / 2$ & 93.3 & $5.5 \times 10^{-2}$ & 4.67 & 2.69 \\
\hline${ }^{87} \mathrm{Rb}$ & $3 / 2$ & 27.85 & 0.13 & 32.84 & $2.8 \times 10^{2}$ \\
\hline${ }^{133} \mathrm{Cs}$ & $7 / 2$ & 100 & $-3 \times 10^{-3}$ & 13.21 & $2.75 \times 10^{2}$ \\
\hline${ }^{9} \mathrm{Be}$ & $3 / 2$ & 100 & $5.3 \times 10^{-2}$ & 14.06 & 78.8 \\
\hline${ }^{45} \mathrm{Sc}$ & $7 / 2$ & 100 & -0.22 & 24.33 & $1.72 \times 10^{3}$ \\
\hline${ }^{89} \mathrm{Y}$ & $1 / 2$ & 100 & - & 4.92 & 0.68 \\
\hline${ }^{139} \mathrm{La}$ & $7 / 2$ & 99.9 & 0.22 & 14.24 & $3.43 \times 10^{2}$ \\
\hline${ }^{51} \mathrm{~V}$ & $7 / 2$ & 99.76 & $-5.2 \times 10^{-2}$ & 26.35 & $2.17 \times 10^{3}$ \\
\hline${ }^{93} \mathrm{Nb}$ & $9 / 2$ & 100 & -0.32 & 24.55 & $2.77 \times 10^{3}$ \\
\hline${ }^{95} \mathrm{Mo}$ & $5 / 2$ & 15.72 & -0.015 & 6.55 & 2.92 \\
\hline${ }^{183} \mathrm{~W}$ & $1 / 2$ & 14.28 & - & 4.22 & $6.08 \times 10^{-2}$ \\
\hline${ }^{77} \mathrm{Se}$ & $1 / 2$ & 7.58 & - & 19.07 & 3.02 \\
\hline${ }^{125} \mathrm{Te}$ & $1 / 2$ & 6.99 & - & 26.17 & 6.99 \\
\hline${ }^{19} \mathrm{~F}$ & $1 / 2$ & 100 & - & 94.09 & $4.73 \times 10^{-3}$ \\
\hline
\end{tabular}

${ }^{a}$ nuclear parameters taken from J. Mason, Multinuclear NMR, Plenum Press, New York, 1987. 
Scheme 1: Heterocrown ligands discussed in this Perspective
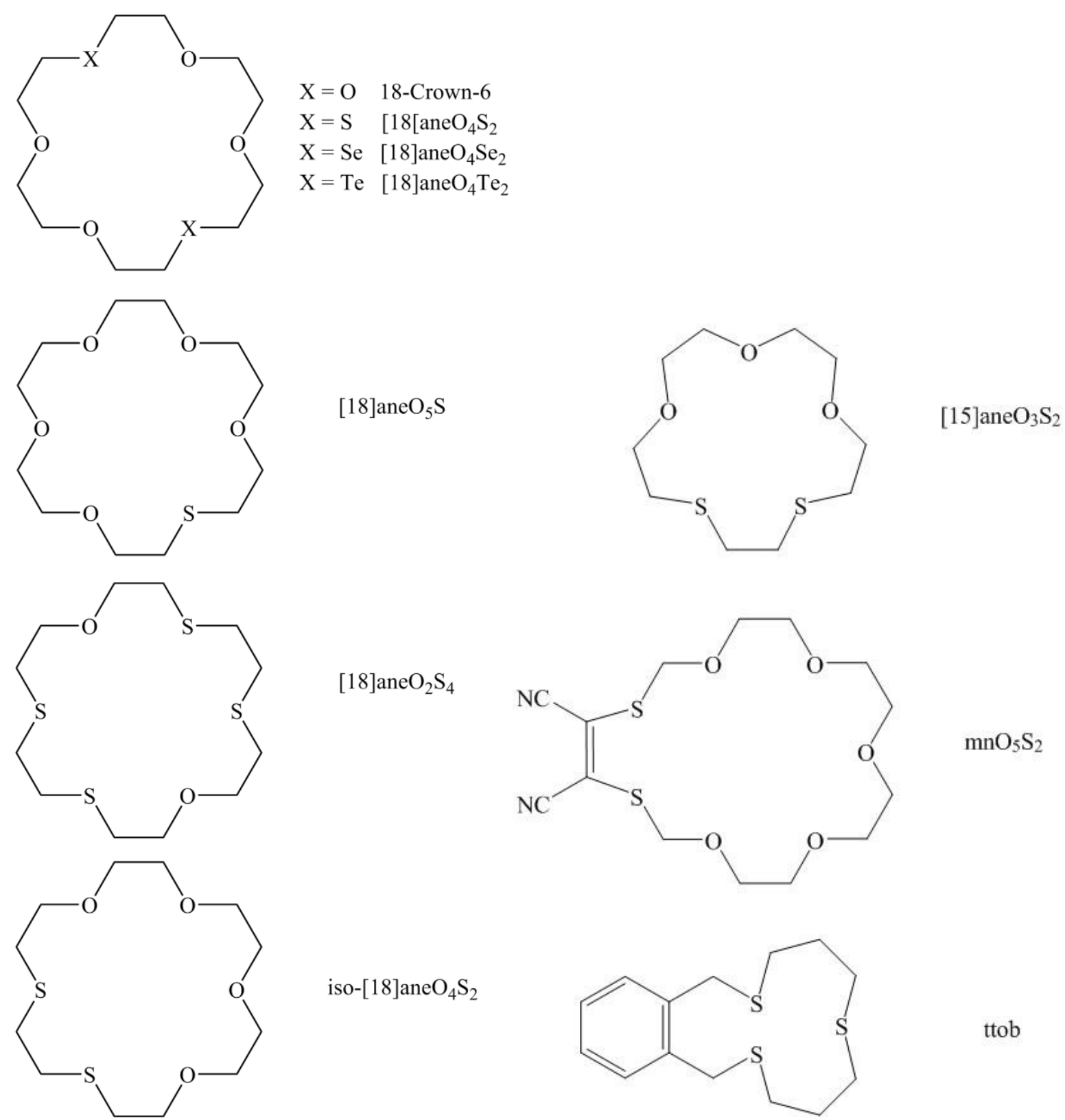

$[18] \mathrm{aneO}_{5} \mathrm{~S}$

$[18] \mathrm{aneO}_{2} \mathrm{~S}_{4}$

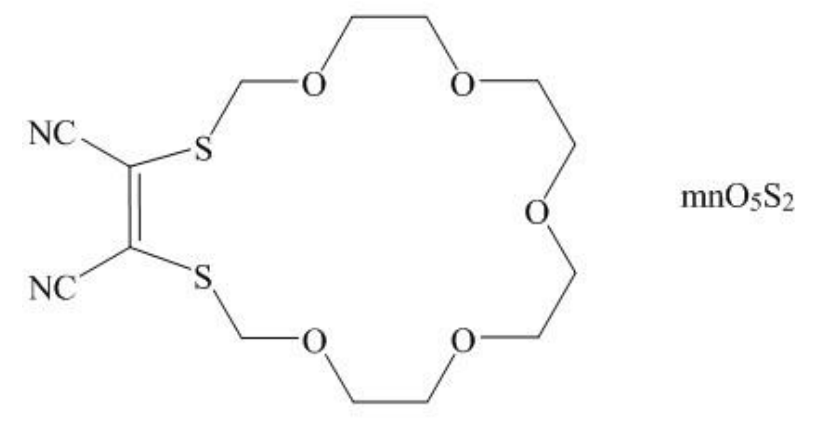

iso-[18] $\mathrm{aneO}_{4} \mathrm{~S}_{2}$<smiles>c1ccc2c(c1)CSCCCCSCCCSC2</smiles> 


\section{S-Block: Group 1 metal chalcogenoether chemistry}

As indicated in the Introduction, complexes of the alkali metals with thioether ligands were expected to be very rare or inaccessible, and the only structurally authenticated examples with mono- or acyclic poly-thioethers appear to be some lithium cuprates, such as $\left[\mathrm{Li}_{2} \mathrm{Cu}_{2}\left(\mathrm{CH}_{2} \mathrm{SiMe}_{3}\right)_{4}\left(\mathrm{Me}_{2} \mathrm{~S}\right)_{2}\right]$ or $\left[\mathrm{Li}_{3} \mathrm{Cu}_{2} \mathrm{Ph}_{5}\left(\mathrm{Me}_{2} \mathrm{~S}\right)_{4}\right]$, made from the $\mathrm{RLi}$ and $\mathrm{CuBr}$ using $\mathrm{Me}_{2} \mathrm{~S}$ as the solvent. The structures show the $\mathrm{Me}_{2} \mathrm{~S}$ bridging between $\mathrm{Li}$ cations with long Li-S bonds $(2.46-2.71 \AA) .{ }^{14}$

Macrocyclic thioethers are more strongly coordinating than their acyclic analogues, but even here the prospects did not appear very promising, with early studies of complexation to $\mathrm{Na}^{+}$or $\mathrm{K}^{+}$in methanol showing that stepwise replacement of $\mathrm{O}$ by $\mathrm{S}$ in 18-crown-6, resulted in sequential falls in the binding constants of several orders of magnitude. ${ }^{15}$ It is clear that any successful synthesis of an alkali metalthioether would require careful design of the reaction conditions and must avoid competing ligands, including donor solvents and moisture. Use of large, weakly coordinating anions is also necessary; with alkali metal halides or oxo-salts the large lattice energies will result in preferential crystallisation of the ligand-free metal salt.

With this in mind, using the large anion in $\mathrm{Na}\left[\mathrm{B}\left\{3,5-\left(\mathrm{CF}_{3}\right)_{2} \mathrm{C}_{6} \mathrm{H}_{3}\right\}_{4}\right] \cdot 2$ thf (the anion is hereafter abbreviated as $\left[\mathrm{BAr}^{\mathrm{F}}\right]^{-}$) and the octathia macrocycle, [24]aneS 8 , in anhydrous $\mathrm{CH}_{2} \mathrm{Cl}_{2}$ solution, produced colourless crystals of $\left[\mathrm{Na}\left([24] \mathrm{aneS}_{8}\right)\right]\left[\mathrm{BAr}^{\mathrm{F}}\right]$. Crystallographic authentication of this species confirms homoleptic $\mathrm{S}_{8}$ coordination (Fig. 1) with long Na-S bonds (2.956-3.052 ̊̊). ${ }^{16}$ DFT calculations indicated significant electron transfer from the S $3 p$ into the $\mathrm{Na} 3 \mathrm{~s}$ and $3 \mathrm{p}$ orbitals, and the calculated bond lengths are in good agreement with the X-ray crystallographically determined data. Attempts to isolate $\mathrm{Li}$ or $\mathrm{K}$ salts in a similar manner were unsuccessful, and it is possible that the very similar conformation of the macrocycle found in the sodium complex and the 'free' macrocycle, indicating a good "fit" (pre-organisation) for the $\mathrm{Na}$, may contribute significantly to the stability of this complex. ${ }^{16}$ The reaction of $\mathrm{Na}\left[\mathrm{BAr}{ }^{\mathrm{F}}\right] \cdot 2$ thf with [9]aneS $\mathrm{S}_{3}$ in $\mathrm{CH}_{2} \mathrm{Cl}_{2}$ produced $\left[\mathrm{Na}\left([9] \mathrm{aneS}_{3}\right)(\text { thf })_{2}\right]\left[\mathrm{BAr}{ }^{\mathrm{F}}\right]$, containing a five-coordinate cation $\left(\mathrm{O}_{2} \mathrm{~S}_{3}\right.$ donor set) (Fig. 2). ${ }^{16}$ No other homoleptic chalcogenoether complexes of the alkali metal ions are currently known, but examples with 18-membered ring oxa-thia and oxa-selena crowns (Scheme 1) are now well established. 


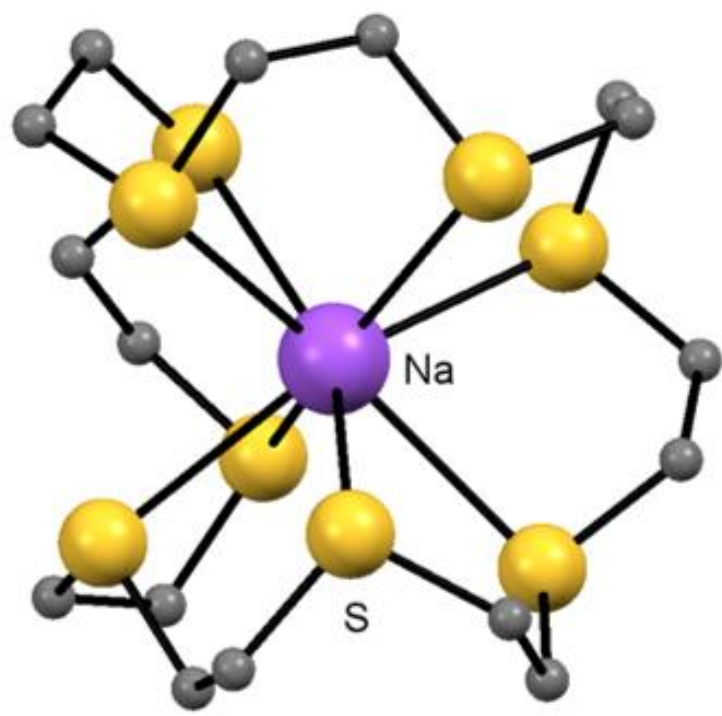

Figure 1. The homoleptic $[\mathrm{Na}([24] \mathrm{aneS} 8)]^{+}$cation redrawn from Reference 16.

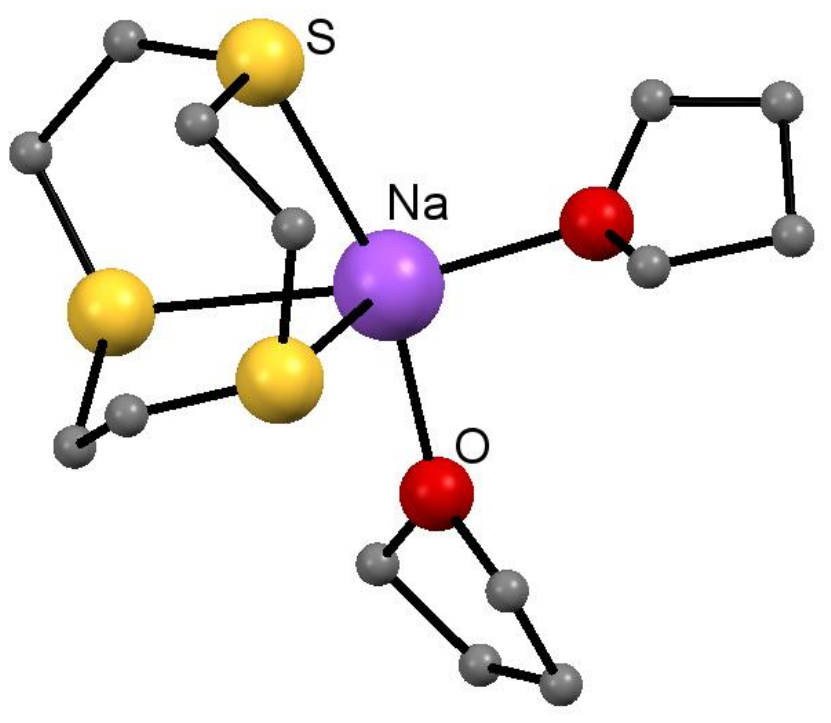

Figure 2. The $\left[\mathrm{Na}\left([9] \mathrm{aneS}_{3}\right)\left(\mathrm{thf}_{2}\right)_{2}\right]^{+}$cation redrawn from Reference 16.

The reaction of $\left[\mathrm{Li}(\text { thf })_{4}\right]\left[\mathrm{BAr}^{\mathrm{F}}\right]$ with [18]aneO $\mathrm{S}_{4} \mathrm{~S}_{2}$ and [18]aneO $\mathrm{S}_{2}$ in anhydrous $\mathrm{CH}_{2} \mathrm{Cl}_{2}$ produced $\left[\mathrm{Li}\left([18] \mathrm{aneO}_{4} \mathrm{~S}_{2}\right)\right]\left[\mathrm{BAr}^{\mathrm{F}}\right]$ and $\left[\mathrm{Li}\left([18] \mathrm{aneO}_{2} \mathrm{~S}_{4}\right)\right]\left[\mathrm{BAr}^{\mathrm{F}}\right]$, the $\mathrm{X}$-ray structures revealing folded macrocycle conformations and distorted octahedral geometries at the lithium, with long $\mathrm{Li}-\mathrm{S}$ bonds (2.54-2.76 А) (Fig. 3). ${ }^{17}$ The distortions are rather less, and the Li-S bonds have a smaller spread (2.54-2.60 $⿱$ A), in $\left[\mathrm{Li}\left([18] \mathrm{aneO}_{2} \mathrm{~S}_{4}\right)\right]\left[\mathrm{BAr}{ }^{\mathrm{F}}\right]$ suggesting [18]aneO ${ }_{2} \mathrm{~S}_{4}$ may be slightly better fit for the small lithium centre. 


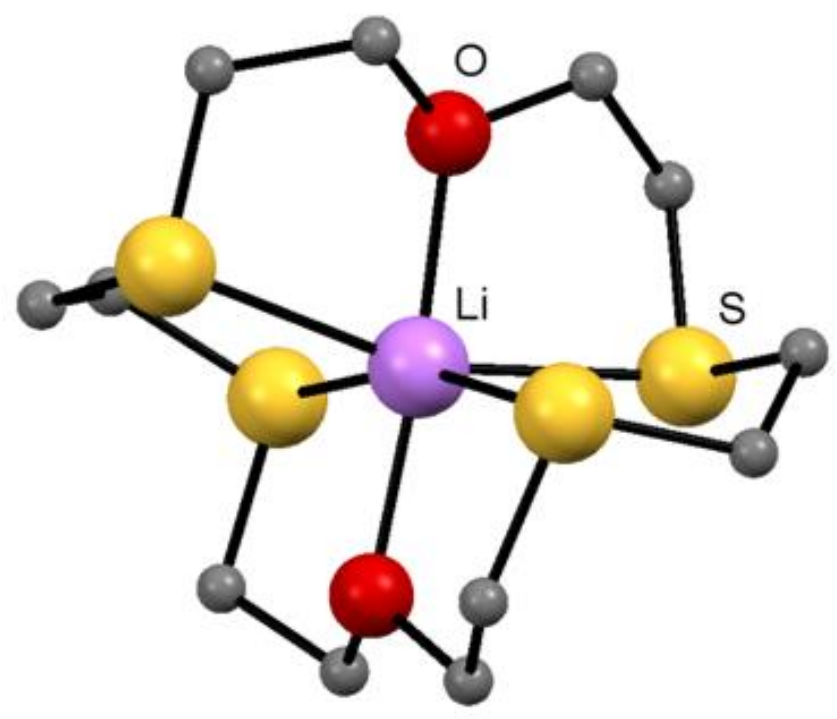

Figure 3. The discrete $\left[\mathrm{Li}\left([18] \mathrm{aneO}_{2} \mathrm{~S}_{4}\right)\right]^{+}$cation redrawn from Reference 17.

The structure of $\left[\mathrm{Na}\left([18] \mathrm{aneO}_{4} \mathrm{~S}_{2}\right)\right]\left[\mathrm{BAr} \mathrm{F}^{\mathrm{F}}\right]$ shows that in addition to the hexadentate coordination of the macrocycle, which has a quite similar conformation to that in the lithium analogue, the larger sodium centre also has a long contact to one $\mathrm{CF}_{3}$ group on the anion $(\mathrm{Na} \cdots \mathrm{F}=3.31 \AA$, which may be compared with the vdW radii sum of $3.96 \AA$ ), resulting in a seven-coordinate metal centre description. ${ }^{17}$ The structure of $\left[\mathrm{Na}\left([18] \mathrm{aneO}_{2} \mathrm{~S}_{4}\right)\right]\left[\mathrm{BAr}{ }^{\mathrm{F}}\right]$ is quite different, with the macrocycle having a chair conformation with planar $\mathrm{S}_{4}$ coordination and with the ether oxygens above and below the plane. Interactions to two anion $\mathrm{CF}_{3}$ groups $\left(\mathrm{Na}^{\cdots} \mathrm{F}=2.88 \AA\right.$ 界) produce a distorted eight-coordinate geometry and result in a chain polymer structure for this compound (Fig. 4). Notably, eightcoordination is also present in $\left[\mathrm{Na}\left(18-\right.\right.$ crown-6)][BAr$\left.{ }^{\mathrm{F}}\right]$, but here the 18 -crown-6 is essentially planar with much shorter trans axial Na $\cdots$ F interactions $(\sim 2.44 \AA) .{ }^{17}$

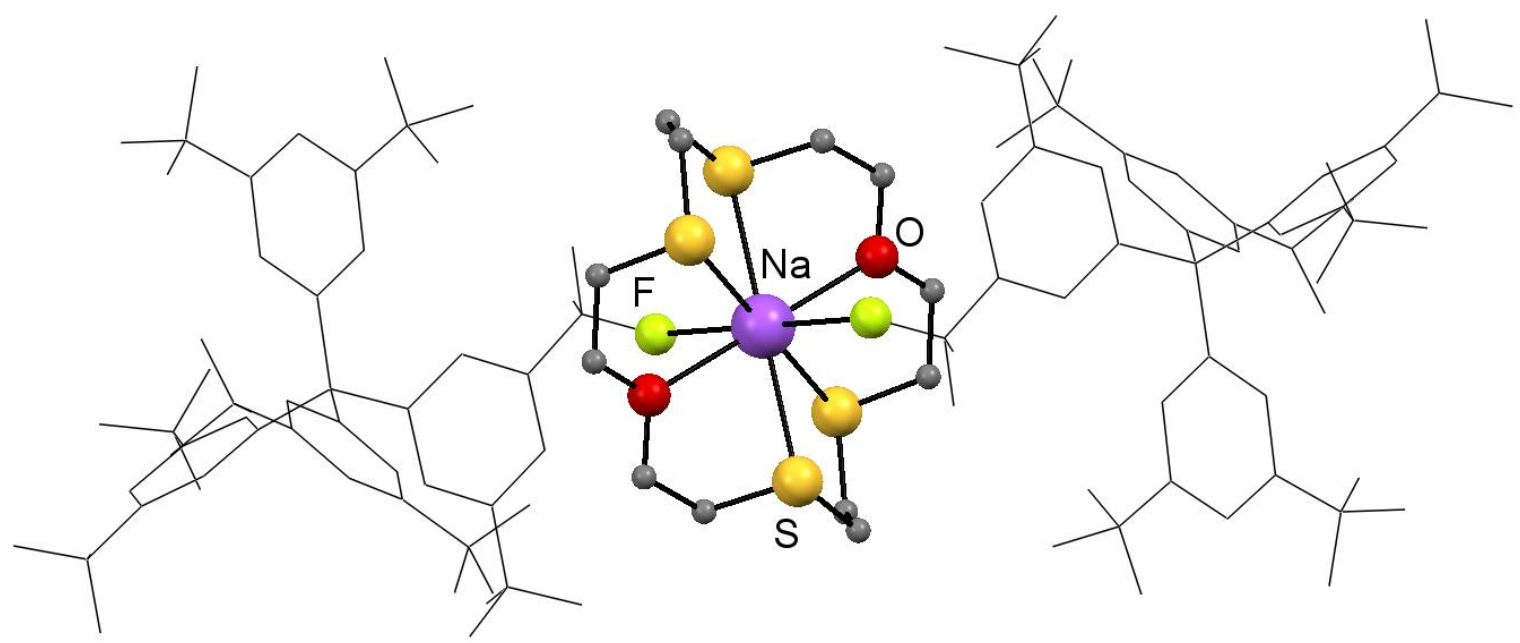

Figure 4. The chain structure in $\left[\mathrm{Na}\left([18] \operatorname{aneO}_{2} \mathrm{~S}_{4}\right)\right]\left[\mathrm{BAr}^{\mathrm{F}}\right]$ redrawn from Reference 17. 
The subtle structural variations continue in the heavier alkali metal complexes with these ligands. In $\left[\mathrm{K}\left([18] \mathrm{aneO}_{4} \mathrm{~S}_{2}\right)\right]\left[\mathrm{BAr}{ }^{\mathrm{F}}\right]$ there are three independent eight-coordinate potassium cations, two which contain two $\mathrm{K} \cdots \mathrm{F}$ interactions on opposite sides of the K-macrocycle plane, and the third with two cis $\mathrm{K} \cdots \mathrm{F}$ interactions. This results in a chain polymer (Fig 5). In contrast, $\left[\mathrm{K}\left([18] \mathrm{aneO}_{2} \mathrm{~S}_{4}\right)\right]\left[\mathrm{BAr}^{\mathrm{F}}\right]$ is isostructural with the sodium salt described above.

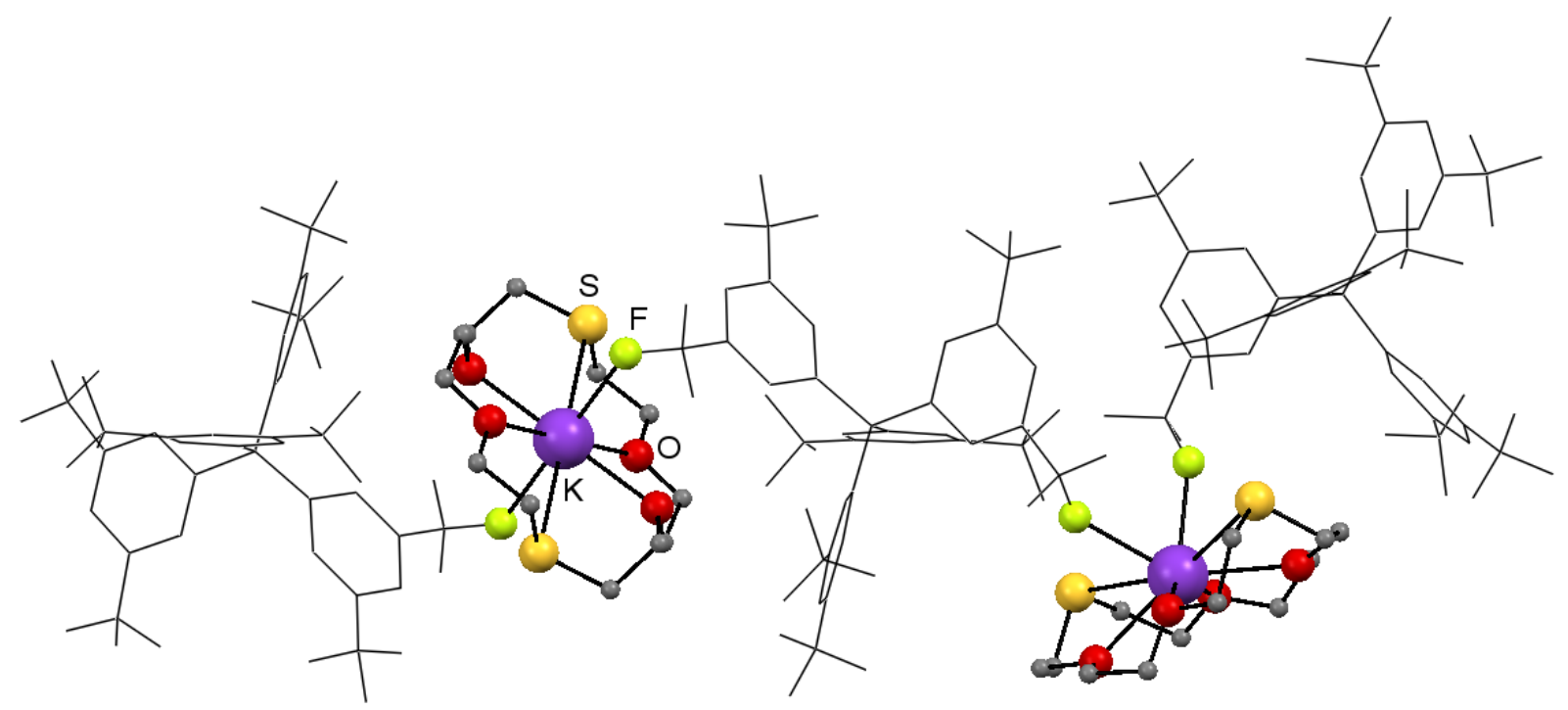

Figure 5. The two coordination environments of the potassium in $\left[\mathrm{K}\left([18] \operatorname{aneO}_{4} \mathrm{~S}_{2}\right)\right]\left[\mathrm{BAr} \mathrm{r}^{\mathrm{F}}\right]$ redrawn from Reference 17.

In $\left[\mathrm{Rb}\left([18] \mathrm{aneO}_{4} \mathrm{~S}_{2}\right)\right]\left[\mathrm{BAr}^{\mathrm{F}}\right]$, which forms as a chain polymer similar to the potassium analogue, one of the rubidium centres appears to be 10-coordinate, with the other two being eight-coordinate. Finally, $\left[\mathrm{Cs}\left([18] \mathrm{aneO}_{4} \mathrm{~S}_{2}\right)\right]\left[\mathrm{BAr}^{\mathrm{F}}\right]$ forms as a sheet polymer with the caesium lying out of the macrocycle plane and with interactions to $\mathrm{F}$ atoms from several disordered $\mathrm{CF}_{3}$ groups. (Fig. 6.)

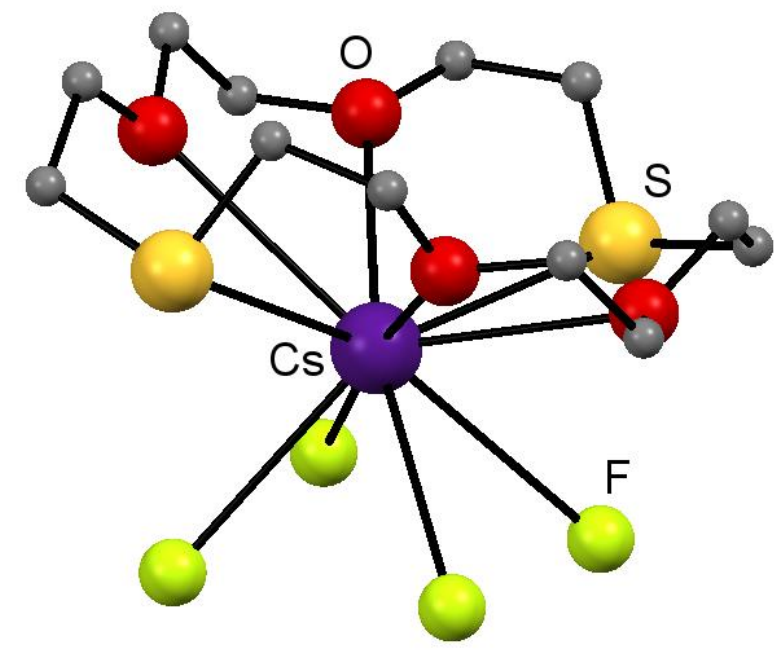

Figure 6. The Cs cation environment in $\left[\mathrm{Cs}\left([18] \operatorname{aneO}_{4} \mathrm{~S}_{2}\right)\right]\left[\mathrm{BAr}^{\mathrm{F}}\right]$; only the $\mathrm{F}$ atoms of the (disordered) $\mathrm{CF}_{3}$ group contacts are shown for clarity, redrawn from Reference 17. 
In all of these complexes the macrocycle is hexadentate, with an increasing number of $\mathrm{M} \cdots \mathrm{F}$ interactions occurring as the metal centre becomes larger, and coordination numbers rising from six at $\mathrm{Li}$, to seven or eight at $\mathrm{Na}$, through to ten at $\mathrm{Cs}^{17}$ As discussed in more detail elsewhere, ${ }^{17}$ the $\mathrm{M}$ donor bond lengths in these complexes are rather long, certainly greater than the sum of the ionic radius of the metal and the covalent radius of the neutral donor atom, but well within the sum of the appropriate $\mathrm{vdW}$ radii. The group 1 complexes are unlikely to retain the anion coordination in solution, and are expected to be undergoing rapid dynamic processes involving the macrocycle, but ${ }^{1} \mathrm{H},{ }^{13} \mathrm{C},{ }^{7} \mathrm{Li},{ }^{23} \mathrm{Na}$ and ${ }^{133} \mathrm{Cs}$ NMR spectroscopy suggest the M-S linkages are retained in solution (K and $\mathrm{Rb}$ isotopes have large quadrupole moments and resonances could not be observed for these systems).

Three [18] $\mathrm{aneO}_{5} \mathrm{~S}$ complexes have been characterised by X-ray crystallography, ${ }^{18}$ and again show interesting trends as the alkali metal cation is changed. In $\left[\mathrm{K}\left([18] \mathrm{aneO}_{5} \mathrm{~S}\right)\right] \mathrm{NCS}$, the hexadentate macrocycle has a boat conformation with weak interactions with the thiocyanate $\mathrm{K} \cdots \mathrm{NCS} \cdots \mathrm{K}$ linking adjacent molecules. In $\left[\mathrm{Rb}\left([18] \mathrm{aneO}_{5} \mathrm{~S}\right)\right] \mathrm{NCS}$, the rubidium lies out of macrocycle plane and interacts with the $\mathrm{NCS}^{-}$ion and with a thioether group on a neighbouring macrocycle (some disorder in this structure hinders confirmation of the details). The sodium salt is quite different in that the sodium is six-coordinate, bonded to five $\mathrm{O}$ 's of the macrocycle and the $\mathrm{N}$ of an isothiocyanate anion, but with the thioether donor directed away from metal centre (Fig. 7) with a non-bonded Na $\cdots \mathrm{S}$ distance of $4.86 \AA{ }^{18}$

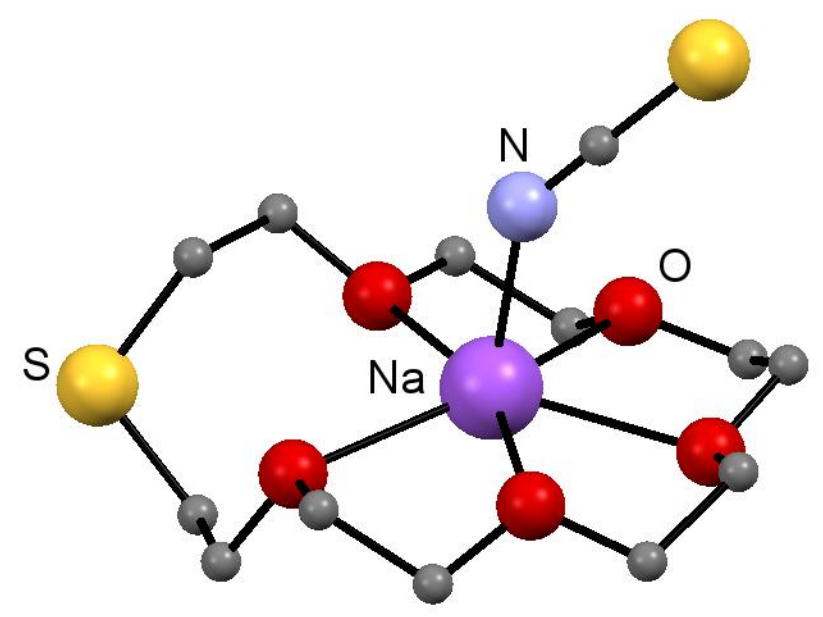

Figure 7. The core structure in $\left[\mathrm{Na}\left([18] \mathrm{aneO}_{5} \mathrm{~S}\right)\right] \mathrm{NCS}$ redrawn from Reference 18.

Lamellar coordination polymers containing iodo- and thiocyanato-cuprates, alkali metals and either [18] $\mathrm{aneO}_{4} \mathrm{~S}_{2}$ or $i s o-[18] \mathrm{O}_{4} \mathrm{~S}_{2}$ have been described, in which the heterocrown is coordinated to the alkali metal with the thioether groups bridging to the $\mathrm{Cu}(\mathrm{I})$ units. ${ }^{19}$ One example is shown in Fig 8 . 


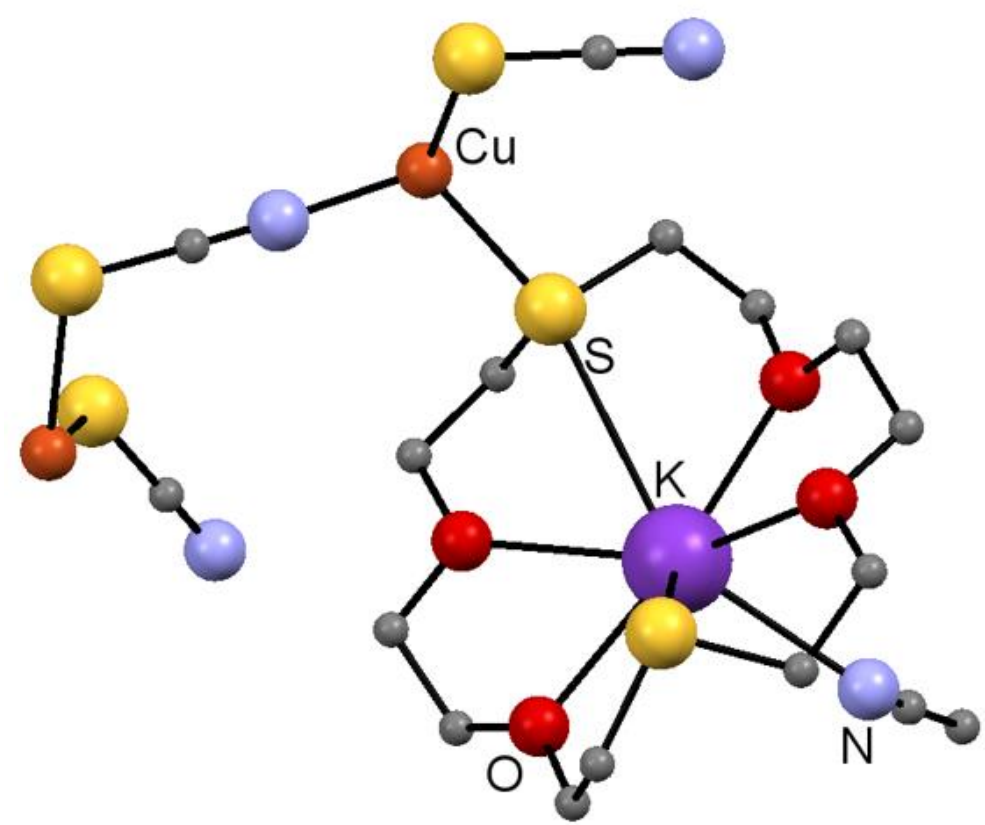

Figure 8. Part of the chain structure present in the polymer $\left[\mathrm{K}\left([18] \mathrm{aneO} \mathrm{O}_{4} \mathrm{~S}_{2}\right) \mathrm{Cu}_{2}(\mathrm{NCS})_{3}\right]$, redrawn from Reference 19.

A heptadentate heterocrown containing a maleonitrile unit, $\mathrm{mnS}_{2} \mathrm{O}_{5}$, forms a seven-coordinate Cs complex of formula $\left[\mathrm{Cs}\left(\mathrm{mnS}_{2} \mathrm{O}_{5}\right)\right]\left[\mathrm{SbCl}_{6}\right] .{ }^{20}$

Complexes of the alkali metal cations coordinated to selenoether groups would be expected to be even rarer than the thioether examples, and none with acyclic ligands or selenium-only macrocycles have been reported. However, [18]aneO ${ }_{4} \mathrm{Se}_{2}$ complexes of $\mathrm{Na}^{+}$and $\mathrm{K}^{+}$have been obtained. ${ }^{17}$ The structure of $\left[\mathrm{Na}\left([18] \mathrm{aneO}_{4} \mathrm{Se}_{2}\right)\right]\left[\mathrm{BAr}^{\mathrm{F}}\right]$ contains seven-coordinate sodium and is similar to that of $\left[\mathrm{Na}\left([18] \mathrm{aneO}_{4} \mathrm{~S}_{2}\right)\right]\left[\mathrm{BAr}{ }^{\mathrm{F}}\right]$ described above, with $\mathrm{Na}-\mathrm{Se}=2.94,2.97 \AA$. The $\left[\mathrm{K}\left([18] \operatorname{aneO}_{4} \mathrm{Se}_{2}\right)\right]\left[\mathrm{BAr}^{\mathrm{F}}\right]$ is isostructural with $\left[\mathrm{K}\left([18] \mathrm{aneO}_{4} \mathrm{~S}_{2}\right)\right]\left[\mathrm{BAr}^{\mathrm{F}}\right]$, with $\mathrm{K}-\mathrm{Se}=3.31 \AA$. These two complexes are the only examples of neutral selenoether coordination to an alkali metal cation.

It should be noted that the thio- or seleno-substituted 18-crown-6 type ligands can coordinate in other systems using only three or four donors, ${ }^{7}$ so that coordination of the chalcogenoether group to the alkali metal cation represents a favourable contribution to the stability of the complex, not simply an inevitable consequence of the macrocycle geometry. The key requirements for such coordination are the absence of competitive stronger donor groups either as small, hard anions or from the solvent, and the use of the large $\left.[\mathrm{BAr}]^{\mathrm{F}}\right]^{-}$anion, which produces soluble precursors, facilitating coordination of the softer donor centres. Further examples of the importance of these factors come from our recent work which used a similar strategy to prepare homoleptic diphosphine complexes of $\mathrm{Li}^{+}$and $\mathrm{Na}^{+}$in

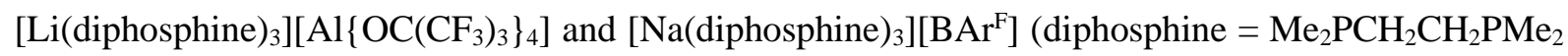
or $\left.o-\mathrm{C}_{6} \mathrm{H}_{4}\left(\mathrm{PMe}_{2}\right)_{2}\right) .{ }^{21}$ 


\section{S-Block: Group 2 metal chalcogenoether chemistry}

Although only explored infrequently due to toxicity concerns, beryllium coordination chemistry contains examples of $\mathrm{Be}(\mathrm{II})$ bonded to most major classes of ligands, with the $\mathrm{Be}-\mathrm{L}$ bonds having significant covalent character. ${ }^{22}$ Adducts of $\mathrm{Me}_{2} \mathrm{~S}$ or $\mathrm{MeSCH}_{2} \mathrm{CH}_{2} \mathrm{SMe}$ with beryllium alkyls and aryls were reported many years ago, ${ }^{23}$ as were $\left[\mathrm{BeCl}_{2}\left(\mathrm{Me}_{2} \mathrm{~S}\right)_{\mathrm{n}}\right](\mathrm{n}=1$ or 2$),{ }^{24}$ although with very limited characterisation. More recently, $\left[\mathrm{BeBr}_{2}\left(\mathrm{Me}_{2} \mathrm{~S}\right)_{2}\right]$ has been prepared from $\mathrm{Be}$ powder, $\mathrm{Br}_{2}$ and $\mathrm{Me}_{2} \mathrm{~S}$ and found to have the expected pseudo-tetrahedral structure with $\mathrm{Be}-\mathrm{Br}=2.12 \AA$ and $\mathrm{Be}-\mathrm{S}=2.17$ $\AA{ }^{25}$ The complex slowly loses $\mathrm{Me}_{2} \mathrm{~S}$ in vacuum at ambient temperatures to form a 1:1 complex of unknown structure, probably $\left[\mathrm{Br}\left(\mathrm{Me}_{2} \mathrm{~S}\right) \mathrm{Be}(\mu-\mathrm{Br})_{2} \mathrm{Be}\left(\mathrm{Me}_{2} \mathrm{~S}\right) \mathrm{Br}\right]$. To-date there are no examples of $\mathrm{Be}$ (II) coordinated to the heavier chalcogenoethers or either chelating or macrocyclic thioethers, although it seems likely that such species will form.

Surprisingly little effort has been devoted to magnesium chalcogenoether chemistry. The reaction of $\left[\mathrm{Mg}(\mathrm{MeCN})_{6}\right]\left[\mathrm{BAr}^{\mathrm{F}}\right]_{2}$ with [18]aneO $\mathrm{S}_{4} \mathrm{~S}_{2}$, [18]ane $\mathrm{O}_{4} \mathrm{Se}_{2}$ or [18] $\mathrm{aneO}_{2} \mathrm{~S}_{4}$ in anhydrous $\mathrm{CH}_{2} \mathrm{Cl}_{2}$ solution produced $\left[\mathrm{Mg}(\mathrm{MeCN})_{2}(\right.$ macrocycle $\left.)\right][\mathrm{BAr}]_{2}$ as extremely moisture sensitive white or yellow powders (Scheme 2). ${ }^{26}$

$$
\begin{aligned}
& {\left[\mathrm{M}(\mathrm{MeCN})_{\mathrm{x}}\right]\left[\mathrm{BAr}^{\mathrm{F}}\right]_{2} \longrightarrow\left[\mathrm{M}(\mathrm{MeCN})_{2} \mathrm{~L}\right]\left\{\mathrm{BAr}^{\mathrm{F}}\right]_{2}} \\
& M=M g, x=6 ; M=C a, x=8 \\
& {\left[\mathrm{Sr}(\mathrm{acacH})(\mathrm{MeCN})_{5}\right]\left[\mathrm{BAr}{ }^{\mathrm{F}}\right]_{2} \stackrel{\mathrm{L}}{\mathrm{CH}_{2} \mathrm{Cl}_{2}} \longrightarrow\left[\mathrm{Sr}(\mathrm{MeCN})_{2} \mathrm{~L}\right]\left[\mathrm{BAr}^{\mathrm{F}}\right]_{2}} \\
& {\left[\mathrm{Ba}(\mathrm{acacH})(\mathrm{MeCN})_{5}\right]\left[\mathrm{BAr}^{\mathrm{F}}\right]_{2} \stackrel{\mathrm{L}}{\mathrm{CH}_{2} \mathrm{Cl}_{2}} \longrightarrow[\mathrm{Ba}(\operatorname{acacH})(\mathrm{MeCN}) \mathrm{L}]\left[\mathrm{BAr}^{\mathrm{F}}\right]_{2}} \\
& \mathrm{CaI}_{2} \underset{\mathrm{MeCN}}{\mathrm{L}}\left[\mathrm{CaI}_{2} \mathrm{~L}\right] \stackrel{\text { trace } \mathrm{H}_{2} \mathrm{O}}{\longrightarrow}\left[\mathrm{Ca}\left(\mathrm{H}_{2} \mathrm{O}\right)_{2} \mathrm{~L}\right]^{2+}
\end{aligned}
$$

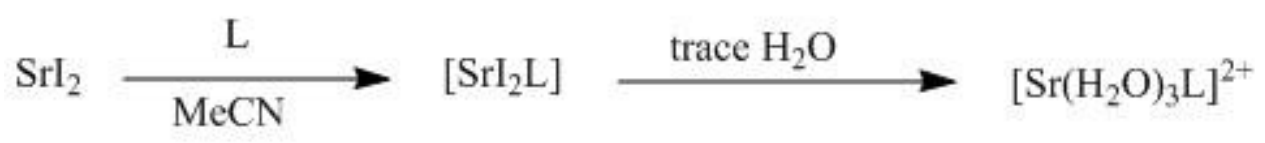

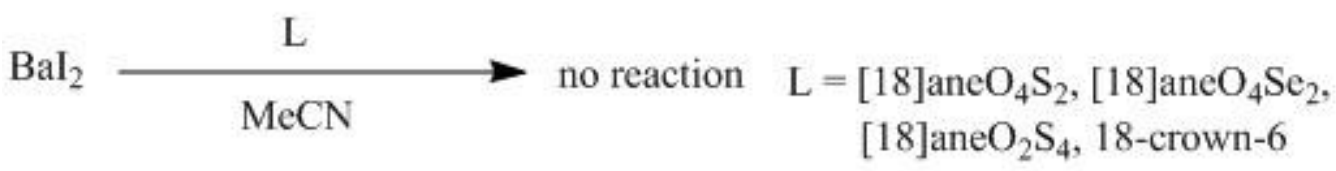

\section{Scheme 2. Synthetic entries into heterocrown complexes of the Group 2 metals}

The IR spectra confirm that the $\mathrm{MeCN}$ is coordinated, but since repeated attempts to obtain X-ray quality crystals failed, the structures of the cations are unclear. The small magnesium centre $\left(r^{+}=0.78\right.$ $\AA ̊ ㇒)$ may not accommodate eight-coordination and the macrocycles may be less than hexadentate in 
these complexes, although one might have expected the remaining $\mathrm{MeCN}$ would have been lost if sixcoordination was present utilising all the heterocrown donors (as in the lithium salt). $\mathrm{In}[\mathrm{Mg}(18-$ crown-6) $\mathrm{Cl}_{2}$ ] the crown is $\kappa^{5}$-coordinated to a seven-coordinate magnesium centre. ${ }^{27}$ During attempts to grow crystals of these complexes from $\mathrm{CH}_{2} \mathrm{Cl}_{2} /$ n-hexane, isomorphous crystals of the hydrolysis products $\left[\mathrm{Mg}(\right.$ macrocycle $\left.)\left(\mathrm{OH}_{2}\right)_{2}(\mathrm{MeCN})\right]\left[\mathrm{BAr}^{\mathrm{F}}\right]_{2} \quad\left(\right.$ macrocycle $=[18] \mathrm{aneO}_{4} \mathrm{~S}_{2}$, [18]aneO $\left.{ }_{4} \mathrm{Se}_{2}\right)$ were obtained (Fig 9), both of which contain 6-coordinate magnesium with $\kappa^{3}\left(\mathrm{O}_{2} \mathrm{E}, \mathrm{E}=\mathrm{S}, \mathrm{Se}\right)$ coordinated macrocycles, and with the coordinated water H-bonded to the two unbound crown oxygen atoms.

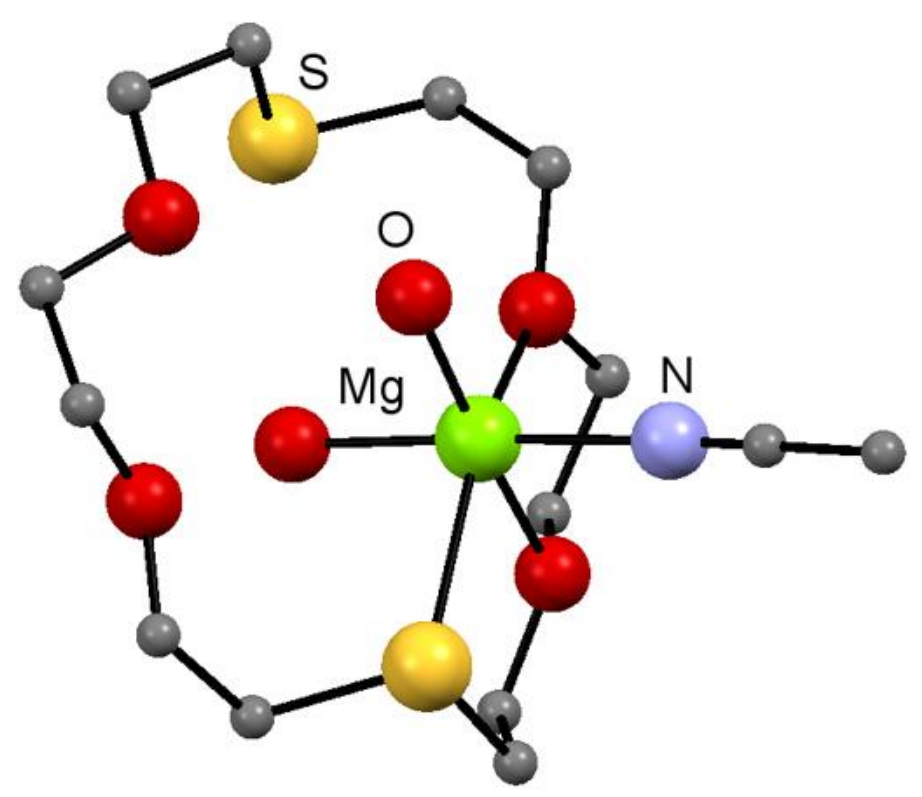

Figure 9. The $\left[\mathrm{Mg}\left(\mathrm{K}^{3}-[18] \mathrm{aneO}_{4} \mathrm{~S}_{2}\right)\left(\mathrm{OH}_{2}\right)_{2}(\mathrm{MeCN})\right]^{2+}$ cation redrawn from Reference 27.

The first calcium complex of [18]aneO $\mathrm{O}_{4} \mathrm{~S}_{2}$ was $\left[\mathrm{Ca}\left([18] \mathrm{aneO}_{4} \mathrm{~S}_{2}\right)\left(\mathrm{ClO}_{4}\right)_{2}\right]$ the structure of which was described as six-coordinate with four oxygens from the heterocrown, two $\kappa^{1}$-perchlorates and with the sulfur producing a "weak interaction rather than a regular bond". ${ }^{28}$ Subsequently, $\left[\mathrm{Ca}\left([18] \mathrm{aneO}_{4} \mathrm{~S}_{2}\right)\left(\mathrm{CF}_{3} \mathrm{SO}_{3}\right)_{2}\right]$ and $\left[\mathrm{CaI}_{2}\left([18] \mathrm{aneO}_{4} \mathrm{~S}_{2}\right)\right]$ were obtained from reactions of the appropriate calcium salt and the ligand in anhydrous MeCN solution. ${ }^{29}$ The triflate shows a similar geometry to the perchlorate complex and all three are better described as distorted eight-coordinate molecules. The differences in $\mathrm{Ca}-\mathrm{O}_{\text {crown }}(2.458-2.533 \AA$ ) and $\mathrm{Ca}-\mathrm{S}(2.949-2.961 \AA)$ are only slightly greater than the differences in covalent radii of $\mathrm{O}$ and $\mathrm{S}$, which whilst indicating that the calcium has a preference for the harder oxygen donor, shows that the $\mathrm{Ca}-\mathrm{S}$ interactions are significant. Attempts to isolate a complex with $\mathrm{CaCl}_{2}$ and [18] $\mathrm{aneO}_{4} \mathrm{~S}_{2}$ resulted in recovery of the starting materials, probably due to the greater lattice energy of the chloride compared to the iodide, although the 18-crown-6 complex, $\left[\mathrm{CaCl}_{2}\right.$ (18-crown-6)], forms readily. ${ }^{29}$ Somewhat unexpectedly, the aquo-complex $\left[\mathrm{Ca}\left([18] \mathrm{aneO}_{4} \mathrm{~S}_{2}\right)\left(\mathrm{OH}_{2}\right)_{2}\right] \mathrm{I}_{2}$ was generated by trace hydrolysis during attempts to grow crystals of the diiodo-complex from $\mathrm{CH}_{2} \mathrm{Cl}_{2}$ solution, where it resulted from displacement by the water of the coordinated iodide ligands, not of the thioether sulfur donors from the heterocrown as might have been 
expected. ${ }^{29}$ Using [18] $\mathrm{aneO}_{2} \mathrm{~S}_{4}$ and $\mathrm{CaI}_{2}$ in anhydrous $\mathrm{MeCN}$ solution produced yellow crystals of $\left[\mathrm{CaI}_{2}\left([18] \mathrm{aneO}_{2} \mathrm{~S}_{4}\right)\right]$, again eight-coordinate with a cis-arrangement of the two iodides, but attempts to isolate a complex with hexathia-macrocycle [18]ane $\mathrm{S}_{6}$, were unsuccessful. ${ }^{29}$ Surprisingly, whilst the $\mathrm{Ca}-\mathrm{S}$ distances in the [18] $\mathrm{aneO}_{2} \mathrm{~S}_{4}$ and [18] $\mathrm{aneO}_{4} \mathrm{~S}_{2}$ complexes were very similar, the $\mathrm{Ca}-\mathrm{O}$ distances were more variable, indicating that other factors, probably including the macrocycle conformation and crystal packing, can affect the bond lengths, and that one should not over interpret the varying distances in these systems. The pentadentate [15] $\mathrm{aneO}_{3} \mathrm{~S}_{2}$ also forms a complex with $\mathrm{CaI}_{2}$, the yellow $\left[\mathrm{CaI}_{2}\left([15] \mathrm{aneO}_{3} \mathrm{~S}_{2}\right)\right]$ represents a rare example of endodentate coordination of this ligand. The X-ray crystal structure showed a seven-coordinate calcium centre with cis-iodides; the $\mathrm{Ca}-\mathrm{O}, \mathrm{Ca}-\mathrm{S}$ and $\mathrm{Ca}-\mathrm{I}$ distances are little different to those in the eight-coordinate species. ${ }^{29} \mathrm{The}$ first example of $\mathrm{Ca}-\mathrm{Se}$ coordination involving a neutral selenoether, was found in the complex $\left[\mathrm{CaI}_{2}\left([18] \mathrm{aneO}_{4} \mathrm{Se}_{2}\right)\right]$ (Fig. 10) which has a similar folded macrocyclic conformation to those found in the [18]ane $\mathrm{O}_{4} \mathrm{~S}_{2}$ and [18] $\mathrm{aneO}_{2} \mathrm{~S}_{4}$ complexes described above, whilst the $\mathrm{Ca}-\mathrm{Se}$ distance is longer than the $\mathrm{Ca}-\mathrm{S}$ distances by an amount consistent with the increased covalent radius of Se, suggesting the interaction is not notably weaker from the softer Se centre. ${ }^{29}$

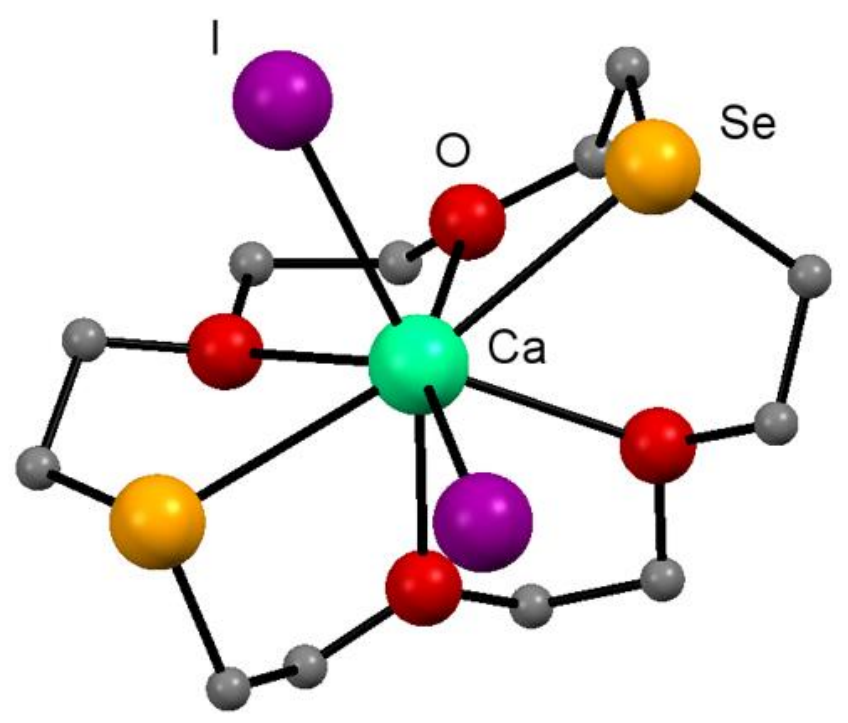

Figure 10. The structure of $\left[\mathrm{CaI}_{2}\left([18] \mathrm{aneO}_{4} \mathrm{Se}_{2}\right)\right]$ redrawn from Reference 29.

The analogous tellurium-containing macrocycle, [18]aneO $\mathrm{Te}_{2}$, did not react with $\mathrm{CaI}_{2}$ in $\mathrm{MeCN}$ solution.

A different approach, using $\left[\mathrm{Ca}(\mathrm{MeCN})_{8}\right]\left[\mathrm{BAr}^{\mathrm{F}}\right]_{2}$ as the calcium source, reacted with [18]ane $\mathrm{O}_{4} \mathrm{~S}_{2}$, [18] $\mathrm{aneO}_{4} \mathrm{Se}_{2}$ and [18] $\mathrm{aneO}_{2} \mathrm{~S}_{4}$ in anhydrous $\mathrm{CH}_{2} \mathrm{Cl}_{2}$ afforded the dications $\left[\mathrm{Ca}\right.$ (heterocrown) $\left(\mathrm{MeCN}_{2}\right]\left[\mathrm{BAr}^{\mathrm{F}}\right]_{2}$ (Scheme 2). The spectroscopic data are dominated by the $\mathrm{BAr}^{\mathrm{F}}$ anions, but the ${ }^{1} \mathrm{H},{ }^{13} \mathrm{C}\left\{{ }^{1} \mathrm{H}\right\}$ NMR and the IR spectra confirm coordination of the macrocycle and the two nitrile ligands. ${ }^{26}$ The $\mathrm{X}$-ray crystal structures reveal an eight-coordinate calcium centre with transnitrile ligands, contrasting with the cis arrangement adopted by the monodentate groups in the calcium complexes described above. The [18] $\mathrm{aneO}_{2} \mathrm{~S}_{4}$ complex is best described as square antiprismatic, whilst 
that of [18]aneO $\mathrm{Se}_{2}$ is dodecahedral. The nitrile ligands in $\left[\mathrm{Ca}\left([18] \mathrm{aneO}_{4} \mathrm{~S}_{2}\right)(\mathrm{MeCN})_{2}\right]^{+}$can be displaced by $2,2^{\prime}$-bipyridyl to form $\left[\mathrm{Ca}\left([18] \mathrm{aneO}_{4} \mathrm{~S}_{2}\right)(\right.$ bipy $\left.)\right]\left[\mathrm{BAr}{ }^{\mathrm{F}}\right]_{2}$, which suggests that the nitrile complexes could offer a general route to new calcium complexes.

Strontium heterocrown complexes made by similar routes to their calcium analogues include $\left[\operatorname{SrI}_{2}\left([18] \mathrm{aneO}_{4} \mathrm{~S}_{2}\right)\right],\left[\mathrm{SrI}_{2}\left([18] \mathrm{aneO}_{4} \mathrm{Se}_{2}\right)\right]$ and $\left[\mathrm{SrI}_{2}\left([15] \mathrm{aneO}_{3} \mathrm{~S}_{2}\right)\right],{ }^{29}$ and constituted the first examples of neutral S- or Se-donor coordination to strontium. They are very sensitive to trace hydrolysis, and again the iodides are displaced preferentially, producing $\left[\operatorname{Sr}\left([18] \mathrm{aneO}_{4} \mathrm{~S}_{2}\right)\left(\mathrm{OH}_{2}\right)_{3}\right] \mathrm{I}_{2}$, $\left[\mathrm{Sr}\left([18] \mathrm{aneO}_{4} \mathrm{Se}_{2}\right)\left(\mathrm{OH}_{2}\right)_{3}\right] \mathrm{I}_{2}$ and $\left[\mathrm{Sr}\left([15] \mathrm{aneO}_{3} \mathrm{~S}_{2}\right)\left(\mathrm{OH}_{2}\right)_{3}\right] \mathrm{I}_{2}$. In $\left[\mathrm{Sr}\left([15] \mathrm{aneO}_{3} \mathrm{~S}_{2}\right)\left(\mathrm{OH}_{2}\right)_{3}\right] \mathrm{I}_{2}$ the three water ligands are arranged mutually cis on an eight-coordinate strontium centre, whilst the two 18membered ring heterocrown complexes are nine-coordinate. In the latter, the three waters are arranged on one side of the metal in the [18] $\mathrm{aneO}_{4} \mathrm{Se}_{2}$ complex, but in that of [18]aneO $\mathrm{O}_{4} \mathrm{~S}_{2}$ (Fig. 11), two are mutually cis and the third trans.
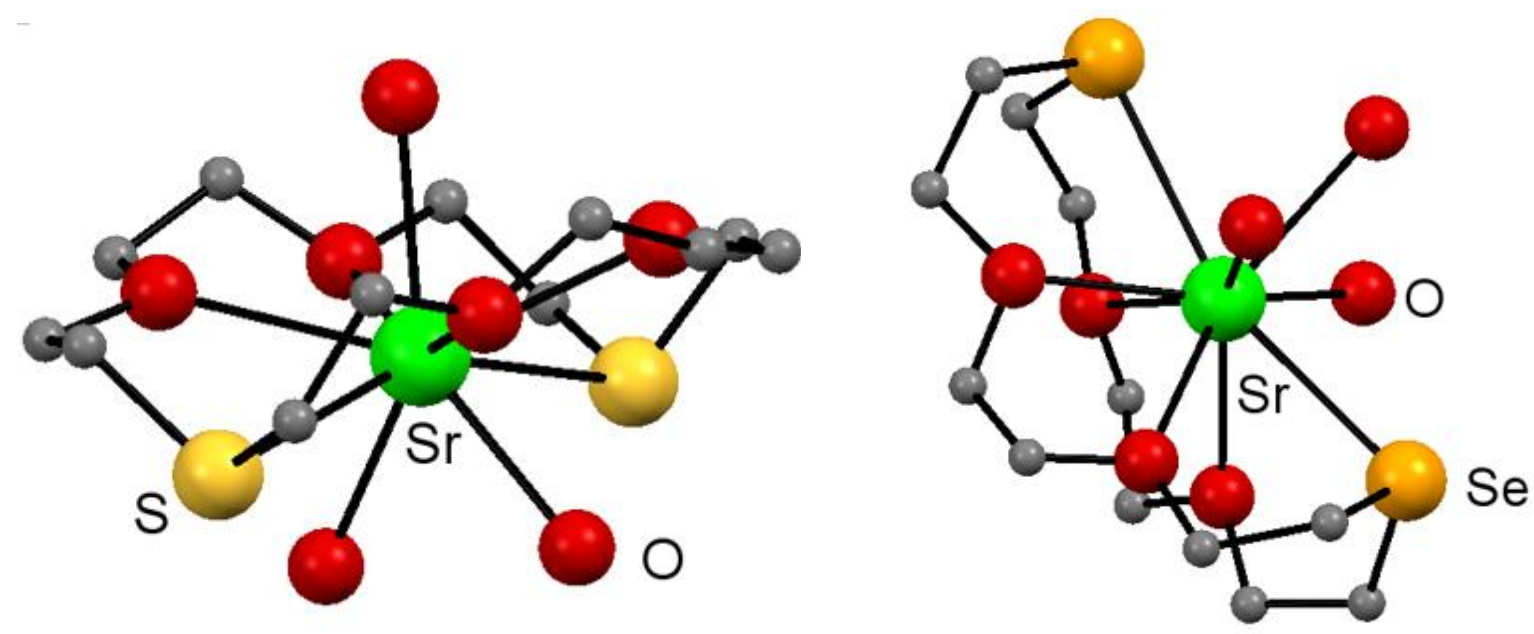

Figure 11. The cations $\left[\mathrm{Sr}\left([18] \mathrm{aneO}_{4} \mathrm{~S}_{2}\right)\left(\mathrm{OH}_{2}\right)_{3}\right]^{2+}$ and $\left[\mathrm{Sr}\left([18] \mathrm{aneO}_{4} \mathrm{Se}_{2}\right)\left(\mathrm{OH}_{2}\right)_{3}\right]^{2+}$ showing the different arrangements of donors, redrawn from Reference 29.

The $\mathrm{Sr}-\mathrm{S}$ and $\mathrm{Sr}-\mathrm{O}$ bond lengths are not sensitive to the stereochemistry adopted, indicating a flexible metal coordination sphere, with the detailed structure presumably a combination of ligand architecture, the metal-donor interactions, and the cation- anion packing, with little energy differences between the various structures found. ${ }^{29}$ Heterocrown complexes with strontium cations, $\left[\mathrm{Sr}\left([18] \mathrm{aneO}_{4} \mathrm{~S}_{2}\right)(\mathrm{MeCN})_{2}\right]\left[\mathrm{BAr}{ }^{\mathrm{F}}\right]_{2}, \quad\left[\mathrm{Sr}\left([18] \mathrm{aneO}_{4} \mathrm{Se}_{2}\right)(\mathrm{MeCN})_{2}\right]\left[\mathrm{BAr}^{\mathrm{F}}\right]_{2} \quad$ and $\left[\mathrm{Sr}\left([18] \mathrm{aneO}_{2} \mathrm{~S}_{4}\right)(\mathrm{MeCN})_{2}\right][\mathrm{BAr}]_{2}$, were made from $\left[\mathrm{Sr}(\mathrm{acacH})(\mathrm{MeCN})_{5}\right]\left[\mathrm{BAr}^{\mathrm{F}}\right]_{2} \quad(\operatorname{acacH}=$ acetylacetone) and the heterocrowns in $\mathrm{CH}_{2} \mathrm{Cl}_{2}$ solution (Scheme 2). ${ }^{27}$ The X-ray structures of $\left[\mathrm{Sr}\left([18] \mathrm{aneO}_{4} \mathrm{~S}_{2}\right)(\mathrm{MeCN})_{2}\right][\mathrm{BAr}]_{2}$ and $\left[\mathrm{Sr}\left([18] \mathrm{aneO}_{4} \mathrm{Se}_{2}\right)\left(\mathrm{MeCN}_{2}\right]\left[\mathrm{BAr}^{\mathrm{F}}\right]_{2}\right.$ (Fig. 12) reveal eightcoordinate strontium centres with trans nitriles; both are dodecahedral but the whilst the [18]aneO ${ }_{4} \mathrm{Se}_{2}$ 
cation is close to the idealised polyhedron, the thioether analogue is severely distorted.

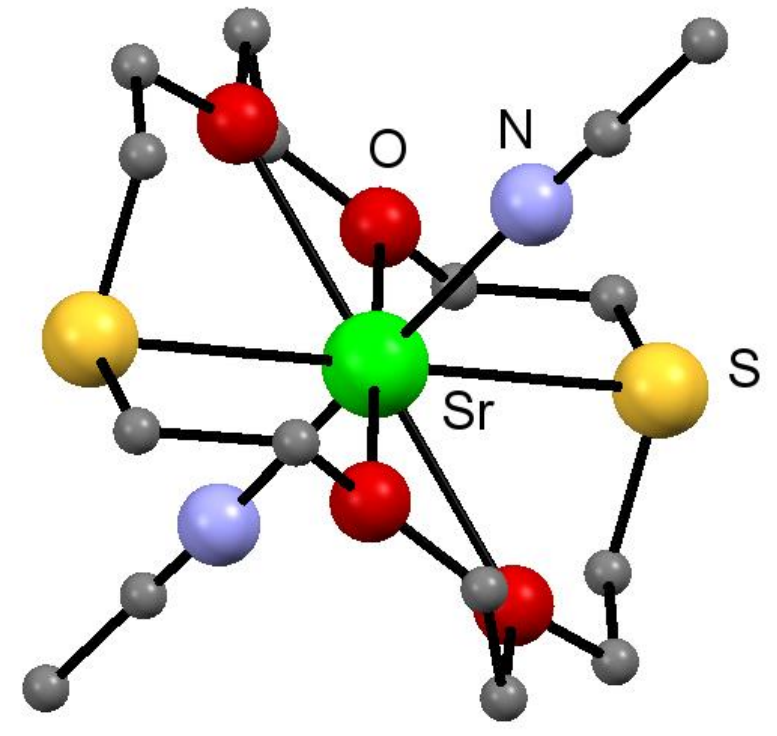

Figure 12. The $\left[\mathrm{Sr}\left([18] \mathrm{aneO}_{4} \mathrm{~S}_{2}\right)(\mathrm{MeCN})_{2}\right]^{2+}$ cation redrawn from Reference 27.

As the metal cation radius increases, its affinity for neutral donor ligands decreases (decreased charge/radius ratio making for a poorer Lewis acid) and attempts to prepare barium complexes of the heterocrowns from $\mathrm{BaI}_{2}$ in $\mathrm{MeCN}$, recovered the starting materials. ${ }^{29}$ However, using $\left[\mathrm{Ba}(\mathrm{acacH})(\mathrm{MeCN})_{5}\right]\left[\mathrm{BAr}^{\mathrm{F}}\right]_{2}$ and [18] $\mathrm{aneO}_{2} \mathrm{~S}_{4}$ or [18]aneO ${ }_{4} \mathrm{Se}_{2}$, produced the nine-coordinate cations, $\left[\mathrm{Ba}\left([18] \mathrm{aneO}_{2} \mathrm{~S}_{4}\right)(\mathrm{acacH})(\mathrm{MeCN})\right]\left[\mathrm{BAr}^{\mathrm{F}}\right]_{2}$ and $\left[\mathrm{Ba}\left([18] \mathrm{aneO}_{4} \mathrm{Se}_{2}\right)(\mathrm{acacH})(\mathrm{MeCN})\right][\mathrm{BAr}]_{2} .^{27}$ In this species the larger barium ( $c f$. strontium above) has increased its coordination number by retaining a neutral acacH ligand (Fig.13). Barium is also present in the lamellar polymer $\left[\mathrm{Ba}\left\{\mathrm{Cu}(\mathrm{SCN})_{3}\right\}_{3}\left([18] \mathrm{aneO}_{4} \mathrm{~S}_{2}\right)\right] .{ }^{19}$

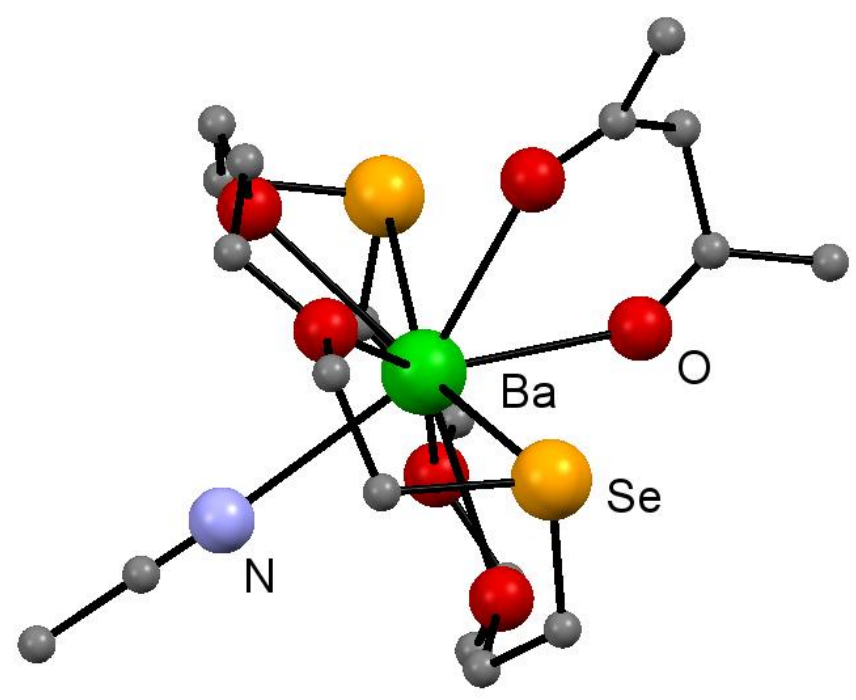

Figure 13. The $\left[\mathrm{Ba}\left([18] \mathrm{aneO}_{4} \mathrm{Se}_{2}\right)(\mathrm{acacH})(\mathrm{MeCN})_{2}\right]^{2+}$ cation redrawn from Reference 27. 


\section{Group 3 metal (Sc and Y) chalcogenoether chemistry}

In this group the metal d-orbitals are now available for $\mathrm{M}-\mathrm{L}$ bonding, so more traditional coordination chemistry might be expected, but the metal centres remain hard Lewis acids. There are no reports of scandium or yttrium halide complexes with macrocycles containing only S- or Se-donor groups, but organometallic complexes of both elements with [9]ane $S_{3}$ have been prepared. ${ }^{30}$ The reaction of $\left[\mathrm{Sc}\left(\mathrm{CH}_{2} \mathrm{SiMe}_{3}\right)_{3}(\text { thf })_{2}\right]$ with [9] $\mathrm{aneS}_{3}$ in toluene produces white $\left[\mathrm{Sc}\left(\mathrm{CH}_{2} \mathrm{SiMe}_{3}\right)_{3}\left([9] \mathrm{aneS} \mathrm{S}_{3}\right)\right]$ which has the expected $f a c$-octahedral structure (Fig 14) with $\mathrm{Sc}-\mathrm{S}=2.793 \AA$ (av).

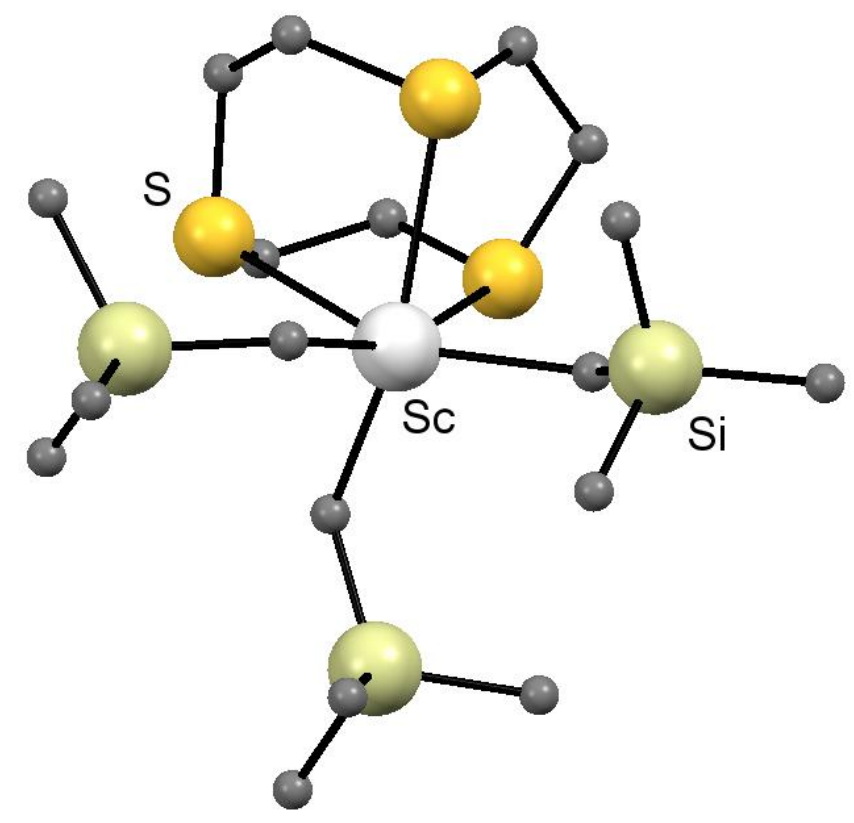

Figure 14. The structure of $\left[\mathrm{Sc}\left(\mathrm{CH}_{2} \mathrm{SiMe}_{3}\right)_{3}\left([9] \mathrm{aneS}_{3}\right)\right]$ redrawn from Reference 30 .

The corresponding yttrium complex has been prepared in solution, but not isolated. ${ }^{30}$ Treatment of $\left[\mathrm{Sc}\left(\mathrm{CH}_{2} \mathrm{SiMe}_{3}\right)_{3}\left([9] \mathrm{aneS}_{3}\right)\right]$ with $\left[\mathrm{CPh}_{3}\right]\left[\mathrm{B}\left(\mathrm{C}_{6} \mathrm{~F}_{5}\right)_{4}\right]$ in $\mathrm{CH}_{2} \mathrm{Cl}_{2}$ produces the fluxional five-coordinate cation, $\left[\mathrm{Sc}\left(\mathrm{CH}_{2} \mathrm{SiMe}_{3}\right)_{2}\left([9] \mathrm{aneS}_{3}\right)\right]^{+}$, which takes up one molecule of thf to form $\left[\mathrm{Sc}_{2}\left(\mathrm{CH}_{2} \mathrm{SiMe}_{3}\right)_{2}\left([9] \mathrm{aneS}_{3}\right)(\text { thf })\right]^{+}$. The $\left[\mathrm{Sc}\left(\mathrm{CH}_{2} \mathrm{SiMe}_{3}\right)_{2}\left([9] \mathrm{aneS}_{3}\right)\right]^{+}$is an active ethylene and $\alpha$-olefin polymerisation catalyst. The corresponding yttrium cation was not isolated, but solution NMR

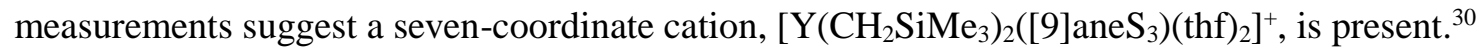

A range of heterocrown complexes of scandium halides have been isolated. ${ }^{31,32}$ Reaction of $\left[\mathrm{ScCl}_{3}(\text { thf })_{3}\right]$ with [15]aneO $\mathrm{S}_{2}$, [18]aneO ${ }_{4} \mathrm{~S}_{2}$ or [18]aneO ${ }_{4} \mathrm{Se}_{2}$ in anhydrous $\mathrm{MeCN}$ solution in the presence of one equivalent of $\mathrm{FeCl}_{3}$ as a chloride abstractor, gave the cations $\left[\mathrm{ScCl}_{2}\right.$ (heterocrown) $]\left[\mathrm{FeCl}_{4}\right]$, whilst direct reaction of the ligands with $\mathrm{ScI}_{3}$ also in dry $\mathrm{MeCN}$ afforded [ScI $\mathrm{S}_{2}$ heterocrown)]I. The X-ray crystal structures of $\left[\mathrm{ScX}_{2}\left([18] \mathrm{aneO}_{4} \mathrm{~S}_{2}\right)\right] \mathrm{Y}\left(\mathrm{X}=\mathrm{Cl}, \mathrm{Y}=\mathrm{FeCl}_{4} ; \mathrm{X}=\right.$ $\mathrm{Y}=\mathrm{I}$ ) show eight-coordinate scandium centres with two cis disposed halides (Fig. 15), ${ }^{32}$ which is notable in comparison with the structure of the $\left[\mathrm{ScCl}_{2}(18 \text {-crown-6) }]^{+}\right.$where only five of the crown oxygens are coordinated, resulting in a pentagonal bipyramidal structure. ${ }^{31}$ The ${ }^{1} \mathrm{H},{ }^{13} \mathrm{C}\left\{{ }^{1} \mathrm{H}\right\},{ }^{45} \mathrm{Sc}$, and 
for the [18]aneO ${ }_{4} \mathrm{Se}_{2}$ complex, ${ }^{77} \mathrm{Se} \mathrm{NMR}$ spectra suggest the heterocrown coordination is maintained in $\mathrm{MeCN}$ solution, but the ${ }^{45} \mathrm{Sc}$ spectra of the iodides suggest the Sc-I coordination has been lost, presumably due to displacement of the soft iodides by the nitrile solvent. The reaction of $\left[\mathrm{ScCl}_{3}(\operatorname{thf})_{3}\right]$, $\mathrm{FeCl}_{3}$ and [18] $\mathrm{aneO}_{4} \mathrm{Te}_{2}$ in $\mathrm{MeCN}$ solution produced a brown solid believed to be $\left[\mathrm{ScCl}_{2}\left([18] \mathrm{aneO}_{4} \mathrm{Te}_{2}\right)\right]\left[\mathrm{FeCl}_{4}\right]$. The ${ }^{1} \mathrm{H}$ NMR spectrum of a freshly prepared solution of the complex in $\mathrm{CD}_{3} \mathrm{CN}$ at $240 \mathrm{~K}$ showed broad features due to the coordinated macrocycle, but on standing at low temperature, or rapidly at ambient temperatures, the solution of the complex decomposed depositing black elemental Te. ${ }^{32}$
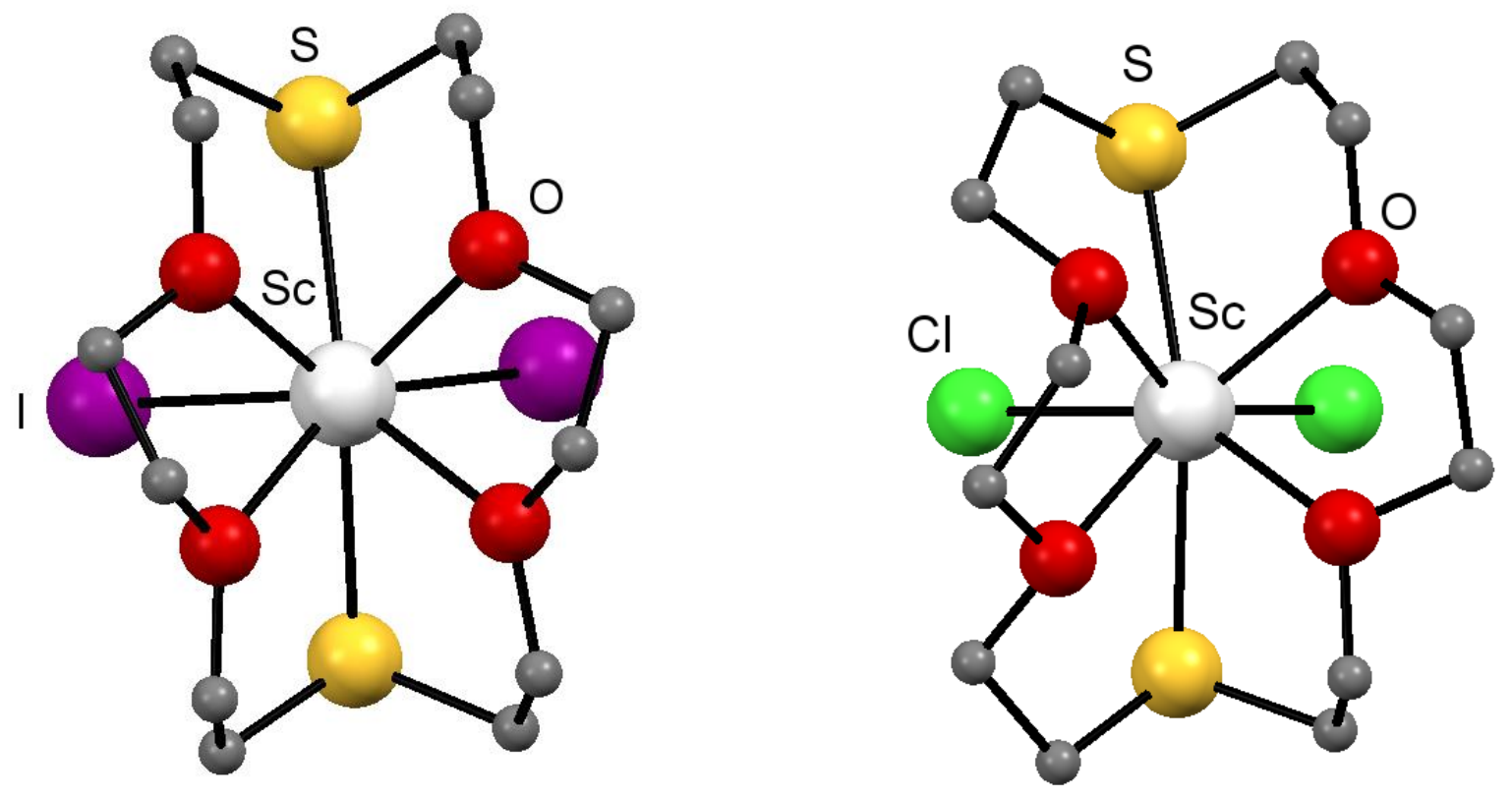

Figure 15. The structures of the cations $\left[\operatorname{ScX}_{2}\left([18] \operatorname{aneO}_{4} S_{2}\right)\right]^{+}(X=I$ (left) and $X=C l$ (right) redrawn from Reference 32.

The heterocrown chemistry of yttrium is similar to that of scandium just described. ${ }^{32}$ The yellow $\left[\mathrm{YCl}_{2}\right.$ (heterocrown) $]\left[\mathrm{FeCl}_{4}\right]$ (heterocrown $=[15] \mathrm{aneO}_{3} \mathrm{~S}_{2}$ or $[18] \mathrm{aneO}_{4} \mathrm{~S}_{2}$ ) were made from $\left[\mathrm{YCl}_{2}(\text { thf })_{5}\right]\left[\mathrm{YCl}_{4}(\text { thf })_{2}\right]$ and the ligand in the presence of the Lewis acidic $\mathrm{FeCl}_{3}$ in $\mathrm{MeCN}$ solution, and the first examples of selenoether coordination to yttrium are found in the related $\left[\mathrm{YCl}_{2}\left([18] \mathrm{aneO}_{4} \mathrm{Se}_{2}\right)\right]\left[\mathrm{FeCl}_{4}\right]$ and $\left[\mathrm{YI}_{2}\left([18] \mathrm{aneO}_{4} \mathrm{Se}_{2}\right)\right] \mathrm{I}$. The ${ }^{77} \mathrm{Se} \mathrm{NMR}$ spectra of the latter show low frequency coordination shifts, with the ${ }^{77} \mathrm{Se}$ chemical shifts unchanged in the presence of added [18] $\mathrm{aneO}_{4} \mathrm{Se}_{2}$, and rather broad ${ }^{1} \mathrm{H}$ NMR spectra. The NMR data were interpreted as showing $\mathrm{Y}-\mathrm{Se}$ coordination retained in solution, whilst the broad ${ }^{1} \mathrm{H}$ NMR spectra indicate some dynamic process, but not complete dissociation of the macrocycle.

As part of a study of early transition metal alkene polymerisation catalysts, light yellow distorted octahedral Sc(III) complexes of neutral tridentate mixed donor R-SNS ligands (R-SNS = $\mathrm{HN}\left(\mathrm{CH}_{2} \mathrm{CH}_{2} \mathrm{SR}\right)_{2}, \mathrm{R}={ }^{\mathrm{t}} \mathrm{Bu}$ or $\left.\mathrm{n}-\mathrm{C}_{10} \mathrm{H}_{21}\right),\left[\mathrm{ScCl}_{3}(\mathrm{R}-\mathrm{SNS})\right]$, were prepared from the ligands and 
$\left[\mathrm{ScCl}_{3}(\mathrm{thf})_{3}\right] \cdot{ }^{33}$ The ${ }^{45} \mathrm{Sc}$ NMR spectra show two resonances in unequal amounts, tentatively attributed to the presence of both $f a c$ and mer isomers. Alkylation with MeLi was studied using a combination of multinuclear NMR and Sc K-edge XAFS spectroscopy, revealing the formation of two species in each ligand system, proposed to be $\left[\mathrm{ScMe}_{3}(\mathrm{R}-\mathrm{SN}(\mathrm{Li}) \mathrm{S})\right]$ and $\left[\mathrm{ScMe}_{2}\left(\mathrm{R}-\mathrm{SN}^{(-)} \mathrm{S}\right)\right]$.

\section{5. f-Block metal chalcogenoether chemistry}

Lanthanide iodides have proved useful synthons since both they and their metal complexes are more soluble in weak donor solvents than the chlorides, presumably due to the lower lattice energy. The resulting complexes are extremely moisture sensitive and trace water preferentially displaces the iodides from the metal centre. $\left[\mathrm{LaI}_{3}\left([9] \mathrm{aneS}_{3}\right)(\mathrm{MeCN})_{2}\right]$ which has a distorted square antiprismatic structure was obtained by diffusion of diethyl ether into a solution of $[9] \mathrm{aneS}_{3}$ and $\left[\mathrm{LaI}_{3}(\mathrm{MeCN})_{4}\right]$ in $\mathrm{MeCN}{ }^{34}$ Using the appropriate $\mathrm{LnI}_{3}$ in anhydrous $\mathrm{MeCN}$ with the heterocrowns produced neutral $\left[\mathrm{LaI}_{3}\left([15] \mathrm{aneO}_{3} \mathrm{~S}_{2}\right)\right],\left[\mathrm{LaI}_{3}\left([18] \mathrm{aneO}_{4} \mathrm{~S}_{2}\right)\right]$, $\left[\mathrm{LaI}_{3}\left([18] \mathrm{aneO}_{4} \mathrm{Se}_{2}\right)\right]$ and $\left[\mathrm{NdI}_{3}\left([18] \mathrm{aneO}_{4} \mathrm{Se}_{2}\right)\right]$, whilst $\mathrm{LuI}_{3}$ formed the cations $\left[\operatorname{LuI}_{2}\left([18] \mathrm{aneO}_{4} \mathrm{~S}_{2}\right)\right] \mathrm{I}$ and $\left[\mathrm{LuI}_{2}\left([18] \mathrm{aneO}_{4} \mathrm{Se}_{2}\right)\right] \mathrm{I}^{32}$ The isomorphous $\left[\mathrm{LaI}_{3}\left([18] \mathrm{aneO}_{4} \mathrm{~S}_{2}\right)\right]$ and $\left[\mathrm{LaI}_{3}\left([18] \mathrm{aneO}_{4} \mathrm{Se}_{2}\right)\right]$ contain nine-coordinate metal centres (Fig. 16) with two iodides on one side of the macrocycle plane and the third on the other.

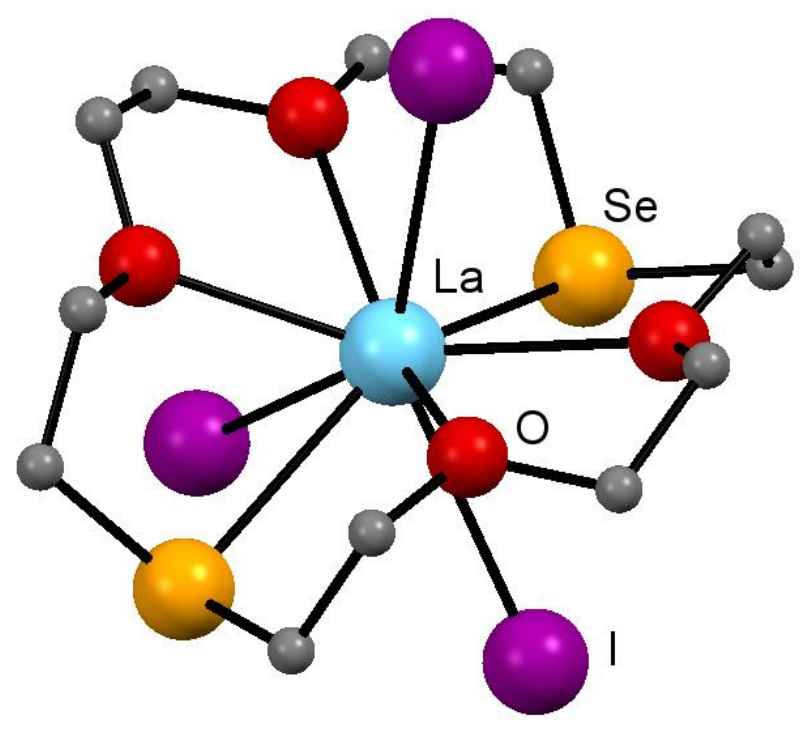

Figure 16. The structure of $\left[\mathrm{LaI}_{3}\left([18] \mathrm{aneO}_{4} \mathrm{Se}_{2}\right)\right]$ redrawn from Reference 32 .

Hydrolysis of the $\left[\mathrm{LaI}_{3}\left([18] \mathrm{aneO}_{4} \mathrm{~S}_{2}\right)\right]$ produced $\left[\mathrm{LaI}\left([18] \mathrm{aneO}_{4} \mathrm{~S}_{2}\right)\left(\mathrm{OH}_{2}\right)_{2}\right] \mathrm{I}_{2} \cdot \mathrm{H}_{2} \mathrm{O}$ which is also ninecoordinate. The eight-coordinate cations in $\left[\operatorname{LuI}_{2}\left([18] \mathrm{aneO}_{4} \mathrm{~S}_{2}\right)\right] \mathrm{I}$ and $\left[\mathrm{LuI}_{2}\left([18] \mathrm{aneO}_{4} \mathrm{Se}_{2}\right)\right] \mathrm{I}$ are isomorphous and contain cis-disposed iodides with structures very similar to the calcium complexes (Fig.17). Despite the change in coordination number the differences in bond lengths in the La and $\mathrm{Lu}$ complexes are much as expected given the smaller radius of $\mathrm{Lu}(\mathrm{III})$. 


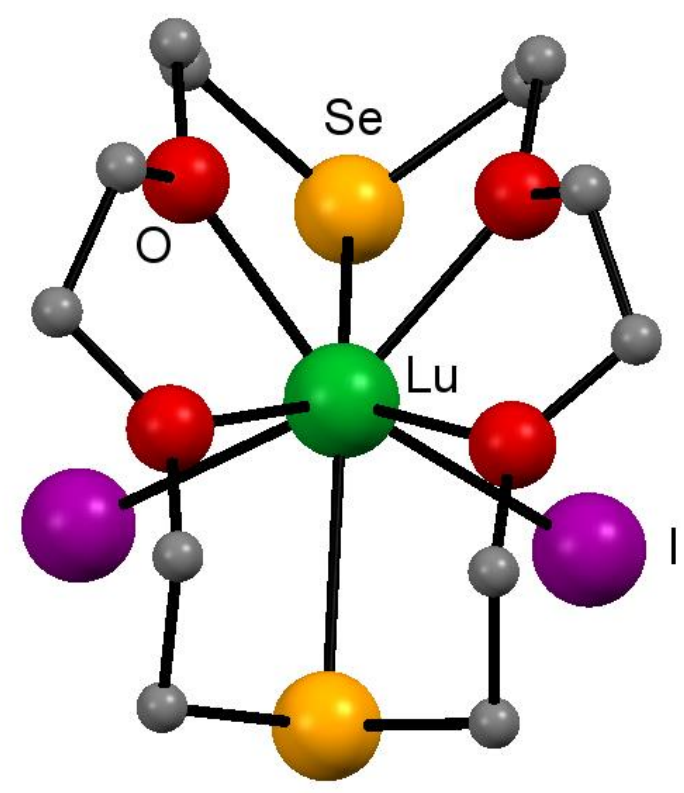

Figure 17. The cation present in $\left[\mathrm{LuI}_{2}\left([18] \mathrm{aneO}_{4} \mathrm{Se}_{2}\right)\right] \mathrm{I}$ redrawn from Reference 32.

The more stable $\mathrm{Ln}(\mathrm{II})$ ions from complexes $\left[\operatorname{LnI}_{2}\left([18] \mathrm{aneO}_{4} \mathrm{~S}_{2}\right)\right](\mathrm{Ln}=\mathrm{Tm}, \mathrm{Sm}, \mathrm{Yb})$ and $\left[\mathrm{YbI}_{2}\left([18] \mathrm{aneO}_{4} \mathrm{Se}_{2}\right)\right]$; the $\mathrm{X}$-ray structure of the $\left[\mathrm{YbI}_{2}\left([18] \mathrm{aneO}_{4} \mathrm{Se}_{2}\right)\right]$ complex confirmed eight coordination is present. ${ }^{35,36}$

The actinides are somewhat softer than the corresponding lanthanides, but whilst there are many examples of Ac-S bonds, ${ }^{37}$ very few involve neutral thioethers.

However, in contrast to the $4 \mathrm{f}$ elements, examples of $5 \mathrm{f}$ elements bonded to simple thioethers have long been known, for example in $\left[\mathrm{UCl}_{4}\left\{\mathrm{MeS}\left(\mathrm{CH}_{2}\right)_{2} \mathrm{SMe}\right\}_{2}\right],{ }^{38}\left[\mathrm{U}\left(\mathrm{C}_{5} \mathrm{H}_{4} \mathrm{Me}\right)_{3}(\right.$ tht $\left.)\right],{ }^{39}$ and $\left[\mathrm{U}\left(\mathrm{BH}_{3} \mathrm{Me}\right)_{4}\left\{\mathrm{MeS}\left(\mathrm{CH}_{2}\right)_{2} \mathrm{SMe}\right\}\right] .{ }^{40}$ The existence of such complexes suggests that the lack of a larger number of actinide thioether (and maybe selenoether) complexes reflects limited efforts to make them, rather than inherent instability.

Recent work has involved thia-macrocycles, for example the synthesis of green $\left[\mathrm{UI}_{3}\left([9] \mathrm{aneS}_{3}\right)(\mathrm{MeCN})_{2}\right],{ }^{34}$ isomorphous with the lanthanum complex described above. A detailed comparison of the bond lengths suggested a stronger (i.e. shorter) interaction in the uranium complex. The highly unusual complex $\left[\mathrm{U}\left(\mathrm{BH}_{4}\right)_{2}\left([18] \mathrm{aneS}_{6}\right)\right]\left[\mathrm{BPh}_{4}\right]$ was obtained from $\left[\mathrm{U}\left(\mathrm{BH}_{4}\right)_{2}(\text { thf })_{5}\right]\left[\mathrm{BPh}_{4}\right]$ and the thiacrown in tht (tetrahydrothiophene) as solvent. ${ }^{41}$ The structure (Fig. 18) may be described as twelve-coordinate with two $\kappa^{3}-\mathrm{BH}_{4}$ ligands or eight coordinate if the $\mathrm{BH}_{4}$ groups which lie mutually cis are conceptually viewed as a single donor group. Notably, similar complexes of [18]ane $\mathrm{S}_{6}$ and $\mathrm{Ce}$ or $\mathrm{Nd}$ could not be prepared. 


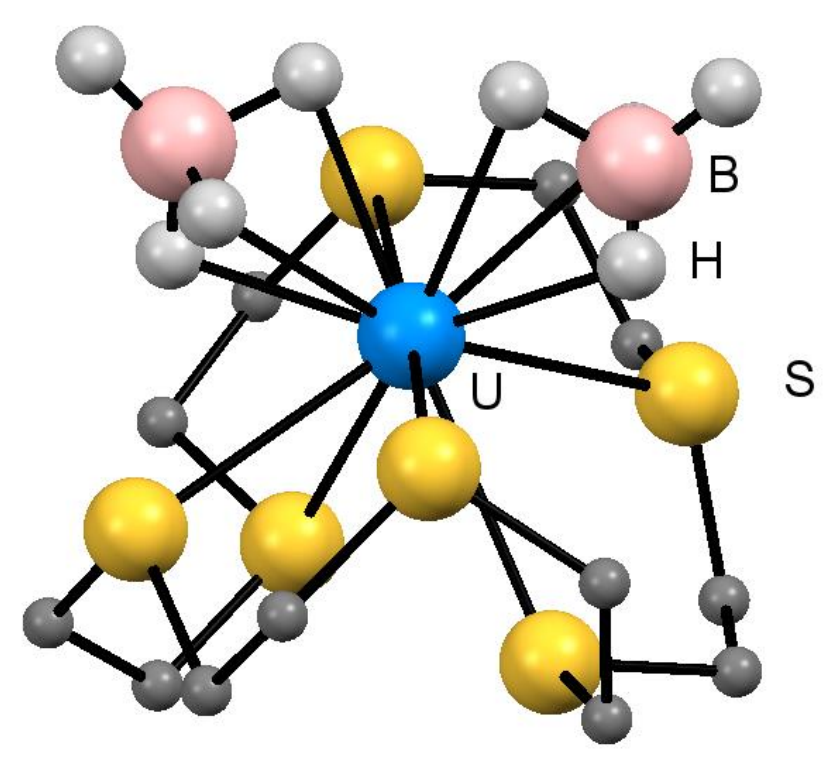

Figure 18. The structure of the $\left[\mathrm{U}\left(\mathrm{BH}_{4}\right)_{2}\left([18] \mathrm{aneS}_{6}\right)\right]^{+}$cation, redrawn from Reference 41.

\section{Group 4 metal ( $\mathrm{Ti}, \mathrm{Zr}$ and Hf) chalcogenoether chemistry}

\subsection{Titanium}

In contrast to the chalcogenoether chemistries described above, most of which have only been explored in recent years, thioether and to some extent selenoether complexes of the tetravalent group 4 metals have been known for many years. ${ }^{1,3}$ There are no reports of telluroether complexes of these metals. The complexes with $\mathrm{TiCl}_{4}$ and $\mathrm{TiBr}_{4}$ with monodentate chalcogenoethers are very moisture sensitive yellow or orange solids of type $c i s-\left[\mathrm{TiX}_{4}\left(\mathrm{R}_{2} \mathrm{E}\right)_{2}\right]\left(\mathrm{X}=\mathrm{Cl}\right.$ or Br$; \mathrm{R}_{2} \mathrm{E}=\mathrm{Me}_{2} \mathrm{~S}, \mathrm{Et}_{2} \mathrm{~S}, \mathrm{Me}_{2} \mathrm{Se}$, tht etc). The preference for cis over trans isomers in these systems has been attributed to the more favourable $\mathrm{X}(\pi)-\mathrm{Ti}(\mathrm{d})$ bonding in the former. Hydrolysis usually completely decomposes the complexes, but traces of water can generate oxido-bridged species, for example $\left[\mathrm{Cl}_{3}\left(\mathrm{Me}_{2} \mathrm{~S}\right)_{2} \mathrm{Ti}(\mu-\right.$ $\mathrm{O}) \mathrm{Ti}\left(\mathrm{Me}_{2} \mathrm{~S}\right)_{2} \mathrm{Cl}_{3}{ }^{42}$ The prospect of using simple $\mathrm{TiX}_{4}$-chalcogenoether complexes as single source precursors for low pressure chemical vapour deposition (LPCVD) of layered $\mathrm{TiE}_{2}$ films, has resulted in detailed re-examination of some of these simple complexes. The $\left[\mathrm{TiCl}_{4}(\mathrm{~L})_{2}\right]\left(\mathrm{L}=\mathrm{Me}_{2} \mathrm{~S}\right.$, tht or cyclo- $\left.\left(\mathrm{CH}_{2}\right)_{5} \mathrm{~S}\right)$ were made from $\mathrm{TiCl}_{4}$ and the thioethers in hexane, and the structure of cis$\left[\mathrm{TiCl}_{4}(\text { tht })_{2}\right]$ determined. ${ }^{43}$ Of the three thioether complexes, only $\left[\mathrm{TiCl}_{4}\left(\mathrm{Me}_{2} \mathrm{~S}\right)_{2}\right]$ was a successful LPCVD source of $\mathrm{TiS}_{2}$. Similar reaction of $\mathrm{TiCl}_{4}$ with $\mathrm{Me}_{2} \mathrm{Se}$ or $\mathrm{Et}_{2} \mathrm{Se}$, followed by vacuum sublimation gave $c i s-\left[\mathrm{TiCl}_{4}\left(\mathrm{R}_{2} \mathrm{Se}\right)_{2}\right]$ (Fig. 19). ${ }^{44}$ 


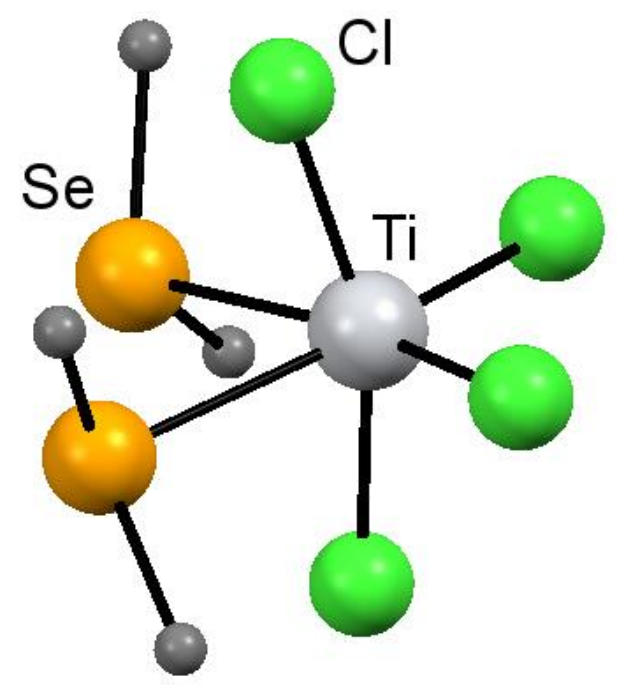

Figure 19. The structure of $c i s-\left[\mathrm{TiCl}_{4}\left(\mathrm{Me}_{2} \mathrm{Se}\right)_{2}\right]$, redrawn from Reference 44 .

The $c i s-\left[\mathrm{TiCl}_{4}\left(\mathrm{Et}_{2} \mathrm{Se}\right)_{2}\right]$ complex deposited air-sensitive $\mathrm{TiSe}_{2}$ thin films at 500-600 ${ }^{\circ}{ }^{44} \mathrm{LPCVD}$ from the more sterically crowded cis-[ $\left[\mathrm{TiCl}_{4}\left({ }^{\mathrm{n}} \mathrm{Bu}_{2} \mathrm{Se}\right)_{2}\right]$, which also has the $\beta$-hydride decomposition route available, produces thicker air-stable films of crystalline hexagonal 1T-TiSe ${ }_{2}$. Substrate selective thin film growth has also been demonstrated using this precursor, with deposition onto the conductive TiN regions of lithographically patterned $\mathrm{TiN} / \mathrm{SiO}_{2}$ substrates strongly preferred (Fig. 20). ${ }^{45}$ Moreover, microfocus diffraction has revealed that increasing $\mathrm{TiSe}_{2}$ crystallite size follows increased TiN holesize.

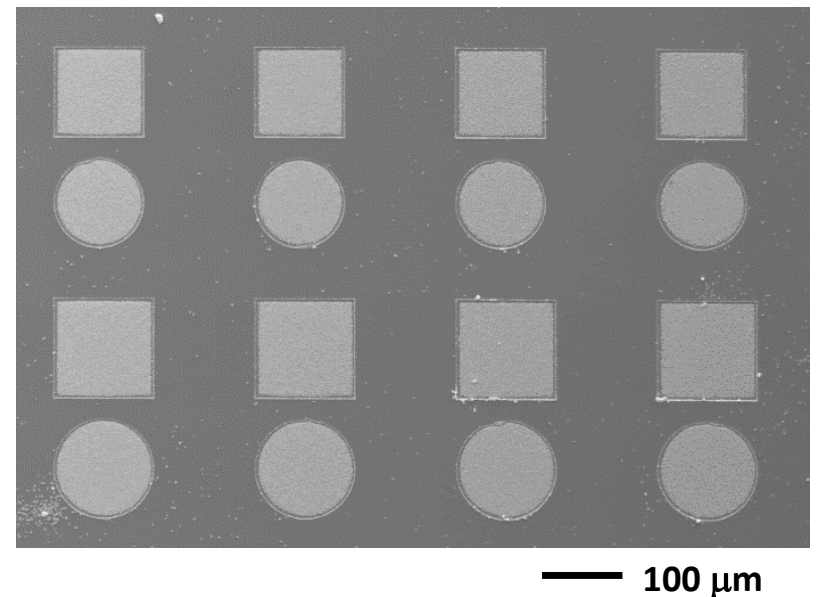

Figure 20 Scanning electron micrograph showing selective deposition of $\mathrm{TiSe}_{2}$ produced from LPCVD using the $c i s$ - $\left[\mathrm{TiCl}_{4}\left({ }^{\mathrm{n}} \mathrm{Bu}_{2} \mathrm{Se}\right)_{2}\right]$ precursor. Light grey regions show the $\mathrm{TiSe}_{2}$ deposited on TiN; dark grey is $\mathrm{SiO}_{2}$.

Systematic studies of dithioether and diselenoether complexes of $\mathrm{TiX}_{4},\left[\mathrm{TiX}_{4}(\mathrm{~L}-\mathrm{L})\right](\mathrm{X}=\mathrm{Cl}, \mathrm{L}-\mathrm{L}=$ $\mathrm{MeE}\left(\mathrm{CH}_{2}\right)_{n} \mathrm{EMe}, \mathrm{n}=2,3, \mathrm{PhE}\left(\mathrm{CH}_{2}\right)_{2} \mathrm{EPh}, o-\mathrm{C}_{6} \mathrm{H}_{4}(\mathrm{EMe})_{2}, o-\mathrm{C}_{6} \mathrm{H}_{4}\left(\mathrm{CH}_{2} \mathrm{EMe}\right)_{2}, \mathrm{E}=\mathrm{S}$, Se; $\mathrm{X}=\mathrm{Br}, \mathrm{L}-\mathrm{L}$ $\left.=\mathrm{MeE}\left(\mathrm{CH}_{2}\right)_{\mathrm{n}} \mathrm{EMe}, \mathrm{n}=2,3, o-\mathrm{C}_{6} \mathrm{H}_{4}(\mathrm{EMe})_{2}\right)$ by IR, UV-visible, multinuclear $\left({ }^{1} \mathrm{H},{ }^{13} \mathrm{C},{ }^{77} \mathrm{Se}\right) \mathrm{NMR}$ 
spectroscopy and X-ray crystallography have also been carried out. ${ }^{46,47}$ In contrast to some diphosphine and diarsine systems, ${ }^{48}$ the chalcogenoethers showed no ability to produce eightcoordination on $\mathrm{Ti}(\mathrm{IV})$. Variable temperature solution $\left(\mathrm{CH}_{2} \mathrm{Cl}_{2}\right)$ NMR data show that the $\mathrm{TiCl}_{4}$ complexes are undergoing fast pyramidal inversion at the chalcogen atom at ambient temperatures but show little evidence of dissociation of the ligands, whereas the $\mathrm{TiBr}_{4}$ complexes are significantly dissociated, indicating Lewis acid strength in these systems is $\mathrm{TiCl}_{4}>\mathrm{TiBr}_{4}$. $\mathrm{TiI}_{4}$ is a very weak Lewis acid and few complexes have been described, but dark red $\left[\mathrm{TiI}_{4}(\mathrm{~L}-\mathrm{L})\right](\mathrm{L}-\mathrm{L}=$ $\mathrm{MeSe}\left(\mathrm{CH}_{2}\right)_{2} \mathrm{SeMe}$ and $o-\mathrm{C}_{6} \mathrm{H}_{4}(\mathrm{SeMe})_{2}$ were successfully characterised. ${ }^{46}$ All the complexes are extremely moisture sensitive and the structure of one (trace) hydrolysis product, $\left[\mathrm{Ti}_{2} \mathrm{Cl}_{6}(\mu-\right.$ O) $\left.\left\{\mathrm{MeS}\left(\mathrm{CH}_{2}\right)_{2} \mathrm{SMe}\right\}_{2}\right]$ was established. ${ }^{46}$ Attempts to prepare thioether complexes of $\mathrm{TiF}_{4}$ were unsuccessful, the reaction of $\left[\mathrm{TiF}_{4}(\mathrm{MeCN})_{2}\right]$ in rigorously anhydrous $\mathrm{CH}_{2} \mathrm{Cl}_{2}$ solution with ${ }^{i} \mathrm{PrS}\left(\mathrm{CH}_{2}\right)_{2} \mathrm{~S}^{\mathrm{i}} \mathrm{Pr}$ resulted in precipitation of (polymeric) $\mathrm{TiF}_{4}$ with no evidence of complex formation. ${ }^{49}$ In addition to simple adduct formation, the diselenoether ligands undergo $\mathrm{C}-\mathrm{Se}$ cleavage under certain condition, e.g. a solution of $\left[\mathrm{TiCl}_{4}\left\{\mathrm{PhSe}\left(\mathrm{CH}_{2}\right)_{2} \mathrm{SePh}\right\}\right]$ in $\mathrm{CHCl}_{3}$ slowly eliminated the backbone to form $\mathrm{PhSeSePh},{ }^{46}$ whilst a by-product of the synthesis of $\left[\mathrm{TiCl}_{4}\left\{o-\mathrm{C}_{6} \mathrm{H}_{4}\left(\mathrm{CH}_{2} \mathrm{SeMe}\right)_{2}\right\}\right]$ was identified by an X-ray crystal structure determination as $\left[\mathrm{C}_{17} \mathrm{H}_{19} \mathrm{Se}_{2}\left[\mathrm{TiCl}_{6}\right]\right.$ (Fig. 21), in which the diselenoether had undergone $\mathrm{C}-\mathrm{Se}$ cleavage and $\mathrm{C}-\mathrm{C}$ coupling to form the cyclic selenonium cation. ${ }^{47}$

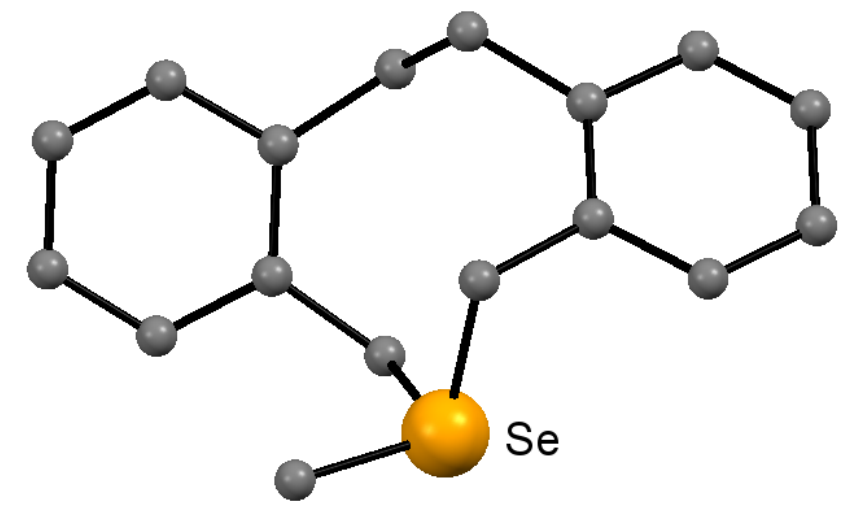

Figure 21. The selenonium cation in $\left[\mathrm{C}_{17} \mathrm{H}_{19} \mathrm{Se}_{2}\left[\mathrm{TiCl}_{6}\right]\right.$ redrawn from Reference 47.

The tripodal $\mathrm{MeC}\left(\mathrm{CH}_{2} \mathrm{EMe}\right)_{3} \quad(\mathrm{E}=\mathrm{S}$ or $\mathrm{Se})$ reacted with $\mathrm{TiCl}_{4}$ or $\mathrm{TiBr}_{4}$ to give $\left[\mathrm{TiX}_{4}\left(\mathrm{MeC}\left(\mathrm{CH}_{2} \mathrm{EMe}\right)_{3}\right)\right]$, which were identified as containing six-coordinate $\mathrm{Ti}(\mathrm{IV})$ with $\kappa^{2}-$ $\left.\left.\mathrm{MeC}\left(\mathrm{CH}_{2} \mathrm{EMe}\right)_{3}\right)\right]$ by variable temperature NMR studies, although with fast exchange between the 'free' and coordinated -EMe groups at room temperature, and with some ligand dissociation in the bromide complexes. ${ }^{50}$

The trithia macrocycles, [9] $\mathrm{aneS}_{3}$ and [10]aneS ${ }_{3}$, form 1:1 complexes with $\mathrm{TiX}_{4}\left(\mathrm{X}=\mathrm{Cl}, \mathrm{Br}\right.$ or I). ${ }^{50,51}$ Unfortunately, all the complexes are insoluble in, or decomposed by, common NMR solvents and as all attempts to obtain crystals have failed, it is unclear if these complexes are six-or seven-coordinate, and if the former, whether they are $\left[\operatorname{TiX}_{3}\left(\kappa^{3}-[n] \mathrm{aneS}_{3}\right)\right] \mathrm{X}$ or $\left[\mathrm{TiX}_{4}\left(\kappa^{2}-[n] \mathrm{aneS}_{3}\right)\right]$. A complex formulated as $\left[\mathrm{TiCl}_{3}\left(\mathrm{~K}^{3}-[9] \mathrm{aneS}_{3}\right)\right]\left[\mathrm{SbCl}_{6}\right]$ was also obtained, ${ }^{50}$ and since this exhibits (apart from the 
$\left[\mathrm{SbCl}_{6}\right]^{-}$vibrations $)$a near identical IR spectrum to that of the tetrachloride complex, the $\left[\mathrm{TiX}_{3}\left(\kappa^{3}-\right.\right.$ $\left.\left.[\mathrm{n}] \mathrm{ane} \mathrm{S}_{3}\right)\right] \mathrm{X}$ formulation may well be correct. The UV-visible and ${ }^{1} \mathrm{H}$ NMR spectra of $\left[\mathrm{TiCl}_{4}\left([15] \mathrm{aneO}_{3} \mathrm{~S}_{2}\right)\right]$ are consistent with $\kappa^{2}$-coordination of the macrocycle via the $\mathrm{S}$ - rather than the O-donors. ${ }^{52}$

t-Butylimido complexes of Ti(IV) with the neutral small ring $\mathrm{S}_{3}$ - and $\mathrm{N}_{2} \mathrm{~S}$-donor macrocycles [9] $\mathrm{aneS}_{3}$ or $\mathrm{Me}_{2}[9] \mathrm{aneN}_{2} \mathrm{~S}(\mathrm{~L})$ of type $\left[\mathrm{TiCl}_{2}(\mathrm{tBuN})(\mathrm{L})\right]$ have been prepared; X-ray crystal structures show the expected fac-octahedral macrocyclic coordination for both. ${ }^{53}$

Titanium(III) thioethers are rare, but include the purple $\left[\mathrm{TiCl}_{3}\left([9] \mathrm{aneS}_{3}\right)\right]^{51}$ and $\left[\mathrm{TiCl}_{3}\left(\mathrm{Bz}_{2} \mathrm{~S}\right)_{3}\right]^{54}$ made from $\mathrm{TiCl}_{3}$ and the ligands in anhydrous $\mathrm{MeCN}$.

\subsection{Zirconium and hafnium}

There has been significantly less work on zirconium or hafnium chalcogenoethers, in part because of the more difficult entry into the chemistry, since the polymeric parent tetrahalides are less useful synthons than their molecular titanium analogues. Both $\mathrm{ZrCl}_{4}$ and $\left[\mathrm{ZrCl}_{4}(\text { thf })_{2}\right]$ reacted slowly and incompletely with a variety of chalcogenoethers, and in some cases the ligands fragmented, e.g. the reaction of $\left[\mathrm{ZrCl}_{4}(\text { thf })_{2}\right]$ with $\mathrm{PhSe}\left(\mathrm{CH}_{2}\right)_{2} \mathrm{SePh}$ in anhydrous $\mathrm{CH}_{2} \mathrm{Cl}_{2}$ immediately turned bright orange, and the diselenide $\mathrm{PhSeSePh}$ was isolated on work-up. ${ }^{55}$ However, $\mathrm{ZrCl}_{4}$ and $\mathrm{HfCl}_{4}$ dissolve easily in $\mathrm{CH}_{2} \mathrm{Cl}_{2}$ containing excess $\mathrm{Me}_{2} \mathrm{~S}$ to form cis- $\left[\mathrm{MCl}_{4}\left(\mathrm{Me}_{2} \mathrm{~S}\right)_{2}\right]$ in high yield. Subsequent reaction of these molecular species with dithioethers or diselenoethers $\left(\mathrm{L}-\mathrm{L}=\operatorname{MeE}\left(\mathrm{CH}_{2}\right)_{\mathrm{n}} \mathrm{EMe}, \mathrm{n}=2,3\right.$, o$\left.\mathrm{C}_{6} \mathrm{H}_{4}\left(\mathrm{CH}_{2} \mathrm{EMe}\right)_{2}, \quad \mathrm{E}=\mathrm{S}, \mathrm{Se}\right)$ readily displaces the volatile $\mathrm{Me}_{2} \mathrm{~S}$, hence providing a much more convenient entry into this chemistry. ${ }^{55}$ Direct reaction of $\mathrm{ZrCl}_{4}$ or the $\mathrm{MI}_{4}(\mathrm{M}=\mathrm{Zr}$ or Hf$)$ with $\mathrm{Et}_{2} \mathrm{Se}$ in anhydrous $\mathrm{CH}_{2} \mathrm{Cl}_{2}$ produces cis-[ $\left.\mathrm{MX}_{4}\left(\mathrm{Et}_{2} \mathrm{Se}\right)_{2}\right] .{ }^{47}$ In addition of simple complex formation, quaternisation of the $\mathrm{R}_{2} \mathrm{E}$ promoted by the Lewis acidic metal halide is sometimes observed. The salts $\left[\mathrm{Et}_{3} \mathrm{Se}_{2}\left[\mathrm{ZrI}_{6}\right]\right.$ and $\left[\mathrm{Me}_{2} \mathrm{SCH}_{2} \mathrm{Cl}_{2}\left[\mathrm{Zr}_{2} \mathrm{Cl}_{10}\right]\right.$ formed in this way as minor by-products have both been crystallographically characterised. ${ }^{47,55}$

In contrast to the titanium systems where only six-coordination has been observed with chalcogenoether ligands irrespective of type, zirconium and hafnium tetrachlorides form both 1:1 and 1:2 complexes with bidentate chalcogenoethers, the former using a stoichiometric amount of ligand, the latter a 1:3 molar ratio. Both series of complexes are colourless, very easily hydrolysed and poorly soluble in weakly coordinating solvents. ${ }^{55}$ With chalcogenoethers capable of forming five-membered chelate rings $\left(\mathrm{MeE}\left(\mathrm{CH}_{2}\right)_{2} \mathrm{EMe}\right)$ examples of six- and eight-coordinate complexes were confirmed (Fig. 22), but unexpectedly the $1: 1$ complex with $\mathrm{MeS}\left(\mathrm{CH}_{2}\right)_{3} \mathrm{SMe}$, was found to be dimeric with bridging dithioether (Fig. 23). ${ }^{55}$ 

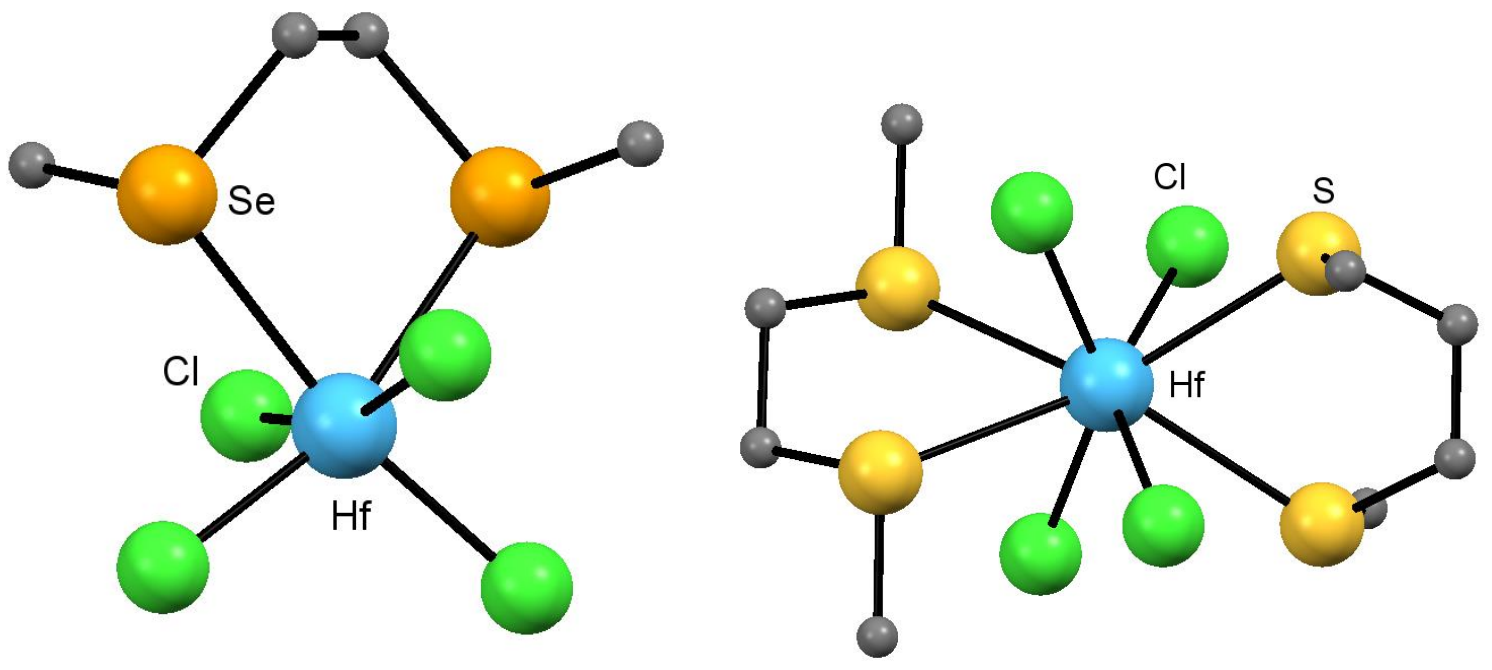

Figure 22. The structures of $\left[\mathrm{HfCl}_{4}\left\{\mathrm{MeSe}\left(\mathrm{CH}_{2}\right)_{2} \mathrm{SeMe}\right\}\right]$ (left) and $\left[\mathrm{HfCl}_{4}\left\{\mathrm{MeS}\left(\mathrm{CH}_{2}\right)_{2} \mathrm{SMe}\right\}_{2}\right]$ (right) redrawn from Reference 55.

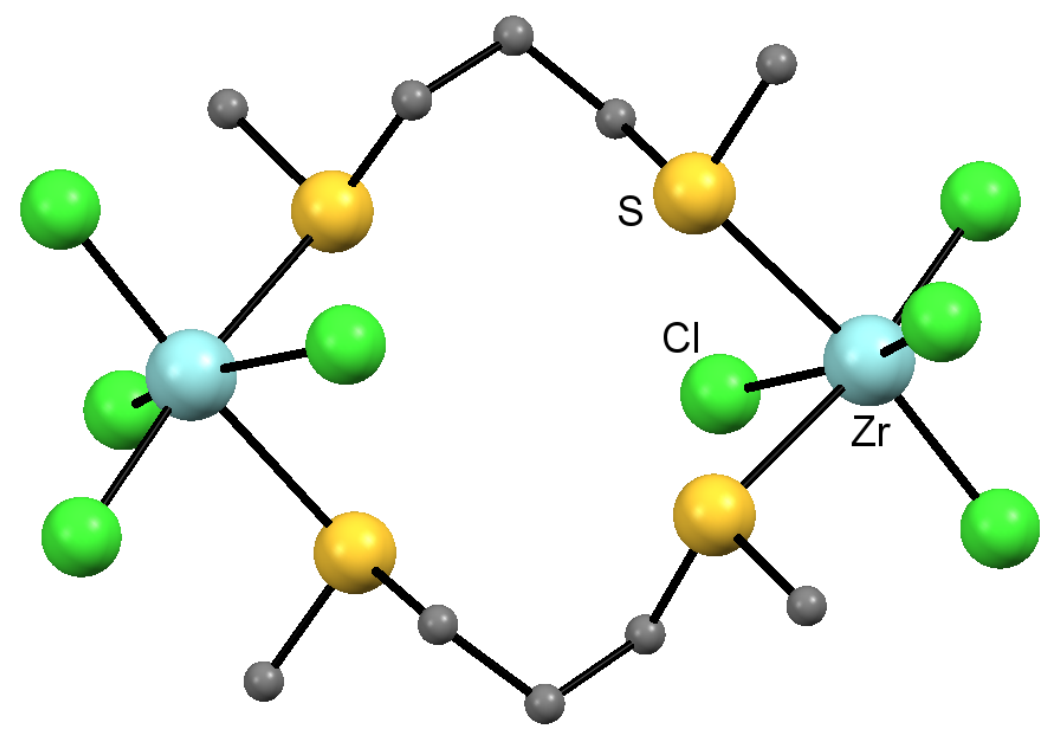

Figure 23. The dimer structure present in $\left[\mathrm{ZrCl}_{4}\left\{\mathrm{MeS}\left(\mathrm{CH}_{2}\right)_{3} \mathrm{SMe}\right\}\right]$ redrawn from Reference 55.

Generally, the complexes are too poorly soluble in weakly coordinating solvents for NMR spectroscopic studies, although for the more soluble $\left[\mathrm{ZrI}_{4}\left\{o-\mathrm{C}_{6} \mathrm{H}_{4}\left(\mathrm{CH}_{2} \mathrm{EMe}\right)_{2}\right\}\right]$, fast pyramidal inversion and fast exchange with added chalcogenoether were observed at room temperature. At 200 $\mathrm{K}$ both processes had slowed and resonances of the meso and $D L$ forms of the coordinated ligand were resolved. ${ }^{47}$ Chalcogenoethers do not appear to be able to form complexes with the very hard (and strongly polymerised) $\mathrm{ZrF}_{4}{ }^{56}$

The tripodal $\mathrm{MeC}\left(\mathrm{CH}_{2} \mathrm{EMe}\right)_{3}\left(\mathrm{E}=\mathrm{S}\right.$ or Se) gave 1:1 complexes on reaction with $\left[\mathrm{MCl}_{4}\left(\mathrm{Me}_{2} \mathrm{~S}\right)_{2}\right]$; the complexes were too poorly soluble to grow crystals or for NMR studies and it is unclear if they are six- or seven coordinate. ${ }^{50}$

The macrocyclic [9] $\mathrm{aneS}_{3}$ and [10]aneS $\mathrm{S}_{3}$ also form poorly soluble $\left[\mathrm{MCl}_{4}\left([\mathrm{n}] \mathrm{aneS} \mathrm{S}_{3}\right)\right]$ complexes, but in this case the X-ray crystal structure of $\left[\mathrm{ZrCl}_{4}\left([9] \mathrm{aneS}_{3}\right)\right]$ was obtained (Fig. 24) and shown to be 
seven-coordinate with the macrocycle $\kappa^{3}$-coordinated..$^{50,55}$ The $\left[\mathrm{MI}_{4}\left([9] \mathrm{aneS}_{3}\right)\right]$ complexes are more soluble in $\mathrm{CH}_{2} \mathrm{Cl}_{2}$ and for these, seven-coordination was confirmed by NMR spectroscopy. ${ }^{47}$

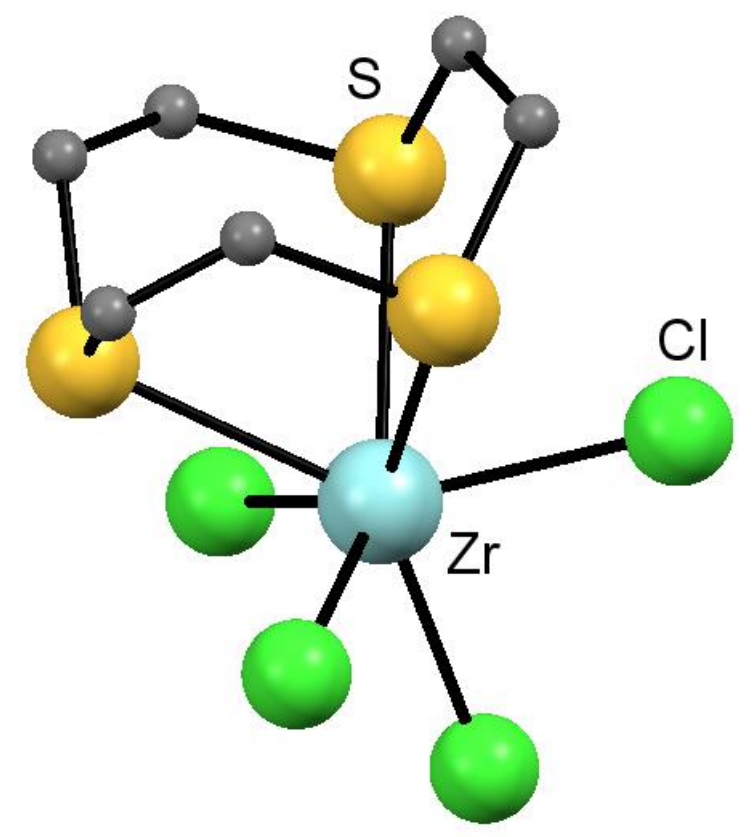

Figure 24. The structure of $\left[\mathrm{ZrCl}_{4}\left([9] \mathrm{aneS}_{3}\right)\right]$ redrawn from Reference 55 .

In contrast to the titanium(IV) analogues, the chalcogenoether complexes of these metals reported todate have not proved to be suitable LPCVD reagents for $\mathrm{ZrE}_{2}$ or $\mathrm{HfE}_{2}$ thin film growth. ${ }^{47,55}$

\section{Group 5 metal ( $\mathrm{V}, \mathrm{Nb}$ and $\mathrm{Ta})$ chalcogenoether chemistry}

\subsection{Vanadium}

In addition to being hard Lewis acids, high oxidation state vanadium centres are easily reduced and the chemistry of vanadium with soft donor ligands is complicated by this ability to switch oxidation states.

\subsubsection{Vanadium $(V)$}

$\mathrm{VOCl}_{3}$ is immediately reduced by $\mathrm{Me}_{2} \mathrm{~S}, \mathrm{Ph}_{2} \mathrm{~S}, \mathrm{Me}_{2} \mathrm{Se}, \mathrm{MeS}\left(\mathrm{CH}_{2}\right)_{3} \mathrm{SMe}$ or $\mathrm{MeSe}\left(\mathrm{CH}_{2}\right)_{2} \mathrm{SeMe}$ to V(IV) or $\mathrm{V}(\mathrm{III}),{ }^{57}$ but with $\mathrm{RS}\left(\mathrm{CH}_{2}\right)_{2} \mathrm{SR}\left(\mathrm{R}=\mathrm{Me}\right.$, Et, $\left.{ }^{\mathrm{i}} \mathrm{Pr}\right)$ which generate five-membered chelate rings, unstable dark red complexes [ $\left.\mathrm{VOCl}_{3}\left\{\mathrm{RS}\left(\mathrm{CH}_{2}\right)_{2} \mathrm{SR}\right\}\right]$ are formed. ${ }^{58}$ The complexes, which decompose in a few hours at ambient temperatures are diamagnetic and exhibit ${ }^{51} \mathrm{~V}$ NMR spectra with chemical shifts only slightly to low frequency of $\mathrm{VOCl}_{3}$. In $\mathrm{MeCN}$ solution $\mathrm{VOF}_{3}$ was reduced by thio- and selenoethers, but reaction of $\left[\mathrm{VOF}_{3}(\mathrm{MeCN})\right]$ with $\mathrm{Me}_{2} \mathrm{~S}$ or $\mathrm{RS}\left(\mathrm{CH}_{2}\right)_{2} \mathrm{SR}$ in anhydrous $\mathrm{CH}_{2} \mathrm{Cl}_{2}$ solution produced cream-coloured $\left[\mathrm{VOF}_{3}\left(\mathrm{Me}_{2} \mathrm{~S}\right)_{2}\right]$ and $\left[\mathrm{VOF}_{3}\left\{\mathrm{RS}\left(\mathrm{CH}_{2}\right)_{2} \mathrm{SR}\right\}\right]$, whose identities were confirmed by IR, ${ }^{1} \mathrm{H},{ }^{19} \mathrm{~F}$ and ${ }^{51} \mathrm{~V}$ NMR spectroscopy. ${ }^{59}$

The redox chemistry in these systems is complicated, but with $\mathrm{Me}_{2} \mathrm{~S}$ and $\mathrm{Me}_{2} \mathrm{Se}$ the corresponding $\mathrm{Me}_{2} \mathrm{SO}$ and $\mathrm{Me}_{2} \mathrm{SeO}$ were identified among the decomposition products, showing that oxygen atom 
transfer is involved to some extent at least. ${ }^{57,58,59}$ Neither $\mathrm{VO}_{2} \mathrm{~F}$ nor $\mathrm{VO}_{2} \mathrm{Cl}$ form complexes with chalcogenoethers. ${ }^{60}$

The thia-macrocycles, [9]aneS $\mathrm{S}_{3}$ and $[18] \mathrm{aneS}_{6}$ form $\left[\mathrm{VOCl}_{3}\left([9] \mathrm{aneS}_{3}\right)\right]$ and $\left[\left(\mathrm{VOCl}_{3}\right)_{2}\left([18] \mathrm{ane} \mathrm{S}_{6}\right)\right]$, but the tetrathioethers, [12]aneS $\mathrm{S}_{4}$ and [14]aneS $\mathrm{S}_{4}$ bring about reduction to $\left[\mathrm{VCl}_{3}\left(\right.\right.$ thiacrown)]. ${ }^{58}$ Crystals of the complexes could not be obtained, but a combination of IR and ${ }^{51} \mathrm{~V}$ NMR spectroscopy, together with vanadium $\mathrm{K}$-edge EXAFS data suggested that the $\left[\mathrm{VOCl}_{3}\left([9] \mathrm{aneS}_{3}\right)\right]$ is $\left[\mathrm{VOCl}_{3}\left(\kappa^{2}-[9] \mathrm{aneS}_{3}\right)\right]$, which is converted $\left[\mathrm{VOCl}_{2}\left(\kappa^{3}-[9] \mathrm{aneS}_{3}\right)\right]\left[\mathrm{SbCl}_{6}\right]$ upon treatment with $\mathrm{SbCl}_{5}{ }^{58}$

\subsubsection{Vanadium(IV)}

The addition of one mol. equivalent of $\mathrm{RS}\left(\mathrm{CH}_{2}\right)_{2} \mathrm{SR}\left(\mathrm{R}=\mathrm{Me}, \mathrm{Et},{ }^{\mathrm{i}} \mathrm{Pr}\right), \mathrm{MeS}\left(\mathrm{CH}_{2}\right)_{3} \mathrm{SMe}$ or 1,4-dithiane to a solution of $\mathrm{VCl}_{4}$ in anhydrous $\mathrm{CH}_{2} \mathrm{Cl}_{2}$ produces the dark violet complexes, $\left[\mathrm{VCl}_{4}\right.$ (dithioether)]. ${ }^{58}$ Use of excess dithioether or heating the solutions causes reduction to V(III) complexes. The paramagnetic ( $\mu_{\mathrm{eff}}$ 1.7-1.9 B.M.) $\left[\mathrm{VCl}_{4}(\right.$ dithioether)] complexes are extremely moisture sensitive, fuming in air and instantly turning blue-green, but, unlike the $\mathrm{VOCl}_{3}$ complexes, they can be stored for weeks in a dry box without degradation. Poor solubility in suitable solvents prevented growth of crystals to provide unambiguous confirmation of the structures, but the UV/visible and IR spectra are consistent with six-coordinate cis isomers. There is also an insoluble purple $\left[\mathrm{VCl}_{4}\left([9] \mathrm{aneS}_{3}\right)\right]$ complex of unknown structure. ${ }^{58}$ Dark purple $\left[\mathrm{VCl}_{4}(\right.$ diselenoether) $]$ (diselenoether $=\mathrm{RSe}\left(\mathrm{CH}_{2}\right)_{2} \mathrm{SeR}, \mathrm{R}=\mathrm{Me}$, ${ }^{\mathrm{n}} \mathrm{Bu}$; $\left.\mathrm{MeSe}\left(\mathrm{CH}_{2}\right)_{3} \mathrm{SeMe}\right)$ were made similarly from $\mathrm{VCl}_{4}$ and the diselenoether in anhydrous $\mathrm{CH}_{2} \mathrm{Cl}_{2}$, but other selenoethers, including $\mathrm{Me}_{2} \mathrm{Se}$, caused immediate reduction to $\mathrm{V}$ (III) ${ }^{61}$

Complexes with $\mathrm{VOCl}_{2}$ are well established and those containing thia-macrocycles are quite robust. Blue crystals of $\left[\mathrm{VOCl}_{2}(\mathrm{MeEtS})_{2}\right]$ formed from $\mathrm{VCl}_{3}$ and $\mathrm{MeEtS}$ in $\mathrm{CH}_{2} \mathrm{Cl}_{2}$, presumably by adventitious air-oxidation or hydrolysis, has a distorted trigonal bipyramidal structure with axial thioethers. ${ }^{62}$ In marked contrast, the red-brown $\left[\mathrm{VOCl}_{2}\left\{\mathrm{RS}\left(\mathrm{CH}_{2}\right)_{2} \mathrm{SR}\right\}\right](\mathrm{R}=\mathrm{Me}$ or Et $)$ were initially obtained by adventitious hydrolysis of the corresponding $\left[\mathrm{VCl}_{4}\left\{\mathrm{RS}\left(\mathrm{CH}_{2}\right)_{2} \mathrm{SR}\right\}\right]$ in dilute $\mathrm{CH}_{2} \mathrm{Cl}_{2}$ solution over several days in a freezer. They may also be synthesised directly from $\mathrm{VCl}_{4},\left(\mathrm{Me}_{3} \mathrm{Si}\right)_{2} \mathrm{O}$ (which promotes $\mathrm{O} / \mathrm{Cl}$ exchange) and $\mathrm{RS}\left(\mathrm{CH}_{2}\right)_{2} \mathrm{SR}$ in $\mathrm{CH}_{2} \mathrm{Cl}_{2} / \mathrm{MeCN}$ solution and have a tetrameric structure based upon a $\mathrm{V}_{4} \mathrm{O}_{4}$ core (Fig. 25)..$^{58}$ 


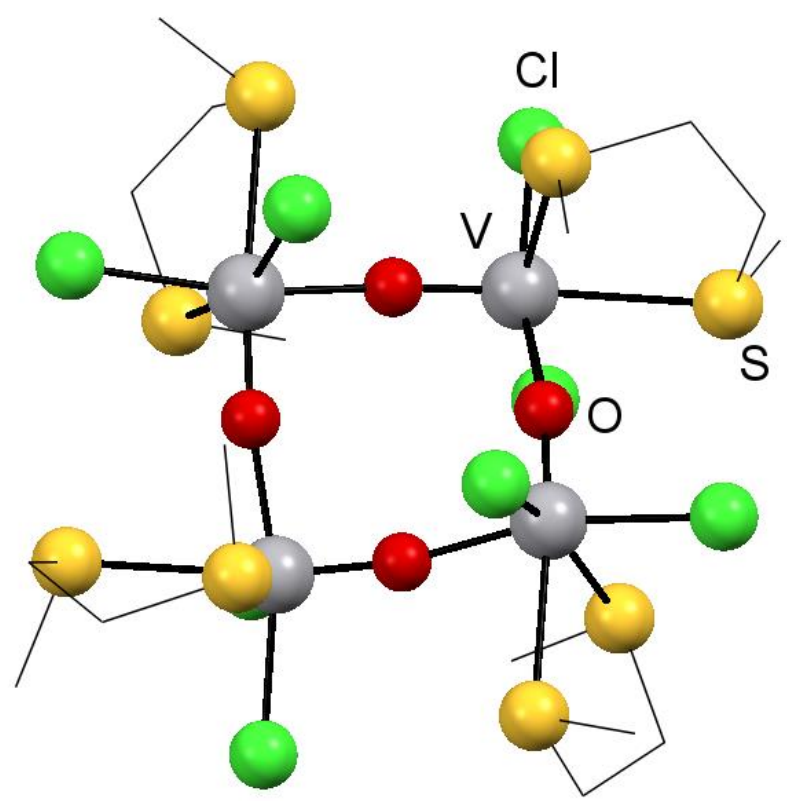

Figure 25. The tetrameric structure of $\left[\operatorname{VOCl}_{2}\left\{\mathrm{MeS}\left(\mathrm{CH}_{2}\right)_{2} \mathrm{SMe}\right\}\right]$ redrawn from Reference 58.

The structure consists of a square with vanadium atoms at the corners, asymmetric, non-linear $\mathrm{V}-\mathrm{O}-\mathrm{V}$ bridges along the edges $\left(\mathrm{V}-\mathrm{O}=1.64,2.00 \AA,<\mathrm{V}-\mathrm{O}-\mathrm{V}=168.6^{\circ}\right)$, with the coordination environment around each vanadium centre completed by a chelating dithioether and two terminal chlorines. The stable deep-blue $\left[\mathrm{VOCl}_{2}\left([9] \mathrm{aneS} \mathrm{S}_{3}\right)\right]$ was originally obtained from prolonged reaction of $\mathrm{VCl}_{3}$ and [9] $\mathrm{aneS}_{3}$ in $\mathrm{MeCN}$ solution and presumably results from oxidation/hydrolysis. ${ }^{63}$ This complex and the related $\left[\mathrm{VOCl}_{2}\right.$ (ttob)] (ttob $=2,5,8$, trithia[9]-o-benzophane) can also be obtained directly from $\left[\mathrm{VOCl}_{2}\left(\mathrm{MeCN}_{2}\right]\right.$ and the macrocycles. ${ }^{64}$ The structure of $\left[\mathrm{VOCl}_{2}\left([9] \mathrm{aneS}_{3}\right)\right]$ shows a distorted octahedral geometry at vanadium. ${ }^{63}$ The $\mathrm{N}_{2} \mathrm{~S}$-donor macrocycle, [9] ane $\mathrm{N}_{2} \mathrm{~S}$, also forms an octahedral complex $\left[\operatorname{VOCl}_{2}\left([9] \mathrm{aneN}_{2} \mathrm{~S}\right)\right]$, the structure of which shows the $\mathrm{S}$ lies trans to $\mathrm{V}=\mathrm{O}$ (Fig 26). ${ }^{65}$ No $\mathrm{VOCl}_{2}$ complexes of selenoethers have been reported, but it seems likely that these should be obtainable.

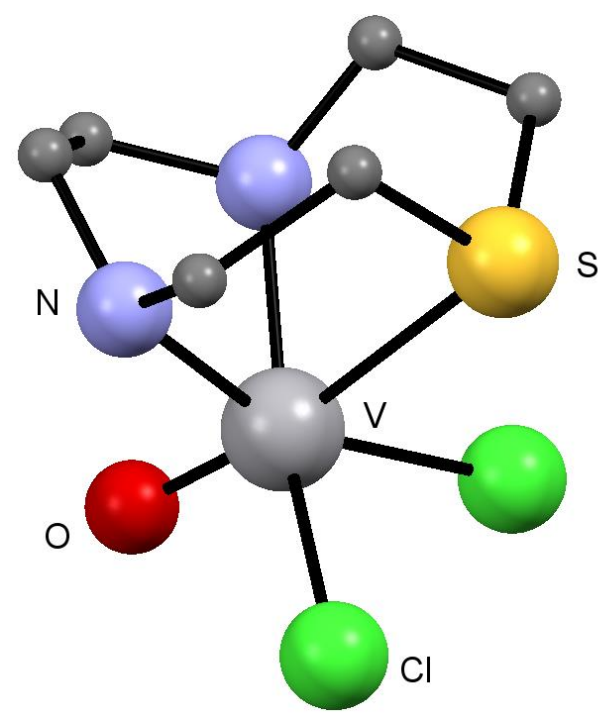




\section{Figure 26. The structure of $\left[\operatorname{VOCl}_{2}\left([9] \mathrm{aneN}_{2} \mathrm{~S}\right)\right]$ redrawn from Reference 65 .}

\subsubsection{Vanadium(III)}

Vanadium(III) is a common oxidation state and thioether complexes were reported many years ago. ${ }^{1}$ Most of these complexes are six-coordinate, although $\left[\mathrm{VCl}_{3}\left(\mathrm{Me}_{2} \mathrm{~S}\right)_{2}\right]$ was an early example of a fivecoordinate species. The pink $\left[\mathrm{VCl}_{3}\left(\mathrm{Me}_{2} \mathrm{Se}\right)_{2}\right]^{61}$ is also probably five-coordinate, but the structures of the pale lilac $\left[\mathrm{VCl}_{3}\right.$ (diselenoether)] (diselenoether $=\operatorname{MeSe}\left(\mathrm{CH}_{2}\right)_{3} \mathrm{SeMe},{ }^{\mathrm{n} B u S e}\left(\mathrm{CH}_{2}\right)_{2} \mathrm{SenB}{ }^{\mathrm{u}}, o-$ $\left.\mathrm{C}_{6} \mathrm{H}_{4}\left(\mathrm{CH}_{2} \mathrm{SeMe}\right)_{2}\right)$, formed by refluxing excess diselenoether with $\mathrm{VCl}_{4}$ in $\mathrm{CH}_{2} \mathrm{Cl}_{2}$, have $\mathrm{UV} /$ visible spectra typical of a six-coordinate $\mathrm{d}^{2}$ ion. ${ }^{61}$ It is likely that they are chloride bridged dimers with structures similar to that found in the $\mathrm{V}(\mathrm{III})$-diarsine complex, $\left[\left\{\mathrm{o}-\mathrm{C}_{6} \mathrm{H}_{4}\left(\mathrm{AsMe}_{2}\right)_{2}\right\} \mathrm{Cl}_{2} \mathrm{~V}(\mu-\mathrm{Cl})_{2} \mathrm{VCl}_{2}\{\mathrm{o}-\right.$ $\left.\left.\mathrm{C}_{6} \mathrm{H}_{4}\left(\mathrm{AsMe}_{2}\right)_{2}\right\}\right] .{ }^{66}$ There are no reports of $\mathrm{V}(\mathrm{III})$ telluroether complexes, but given current knowledge of the lighter chalcogenoether complexes, these should be obtainable with correct choice of ligand and reaction conditions. LPCVD of $\left[\mathrm{VCl}_{3}\left(\mathrm{Me}_{2} \mathrm{Se}\right)_{2}\right]$ produced thin films of $\mathrm{VSe}_{2}{ }^{61}$

Thia-macrocycle complexes are well established, including $\left[\mathrm{VX}_{3}(\mathrm{~L})\right]\left(\mathrm{L}=[9] \mathrm{aneS}_{3},[10] \mathrm{aneS}_{3}\right.$, [9] ane $\mathrm{OS}_{2}, \mathrm{X}=\mathrm{Cl}, \mathrm{Br}$ or I) and $\left[\mathrm{VCl}_{3}(\mathrm{ttob})\right]^{64,67,68,69} \mathrm{The}$ fac-octahedral structure has been established by X-ray crystallography for $\left[\mathrm{VCl}_{3}([9] \mathrm{aneS})\right]$ (Fig. 27) and several others have been examined by vanadium K-edge EXAFS studies.

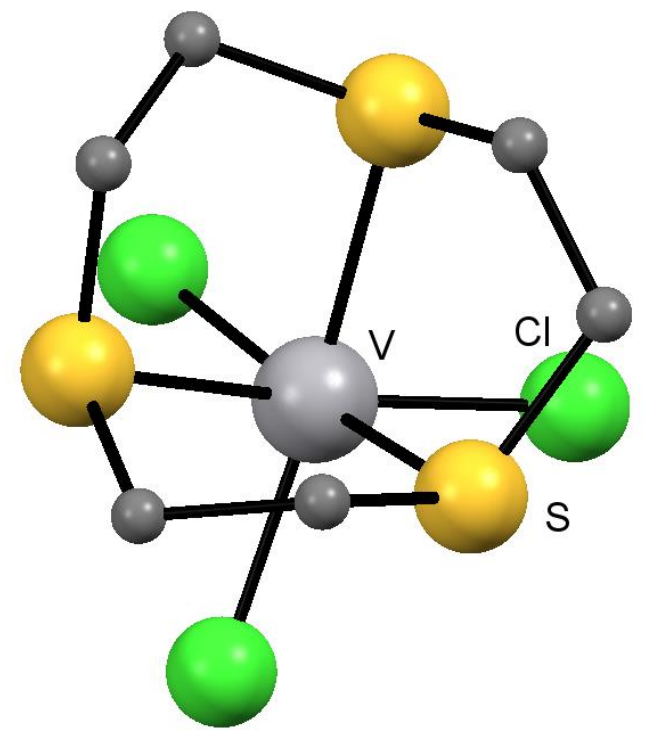

Figure. 27 The structure of $\left[\mathrm{VCl}_{3}([9] \mathrm{aneS})_{3}\right]$ redrawn from Reference 64 .

The $\left[\left(\mathrm{VCl}_{3}\right)_{2}\left([18] \mathrm{ane} \mathrm{S}_{6}\right)\right]$ also contains $\mathrm{fac}-\mathrm{Cl}_{3} \mathrm{~S}_{3}$ coordination at each vanadium, and it is likely that $\left[\mathrm{VCl}_{3}([12] \mathrm{aneS})\right]$ is similar, with a $\kappa^{3}$-tetrathiacyclododecane ligand. ${ }^{64}$ The $\left[\mathrm{VCl}_{3}\left(\kappa^{3}\right.\right.$-heterocrown $\left.)\right]$ (heterocrown $=[15] \mathrm{aneO}_{3} \mathrm{~S}_{2}$ or $\left.[18] \mathrm{aneO}_{3} \mathrm{~S}_{3}\right)$ are assigned as octahedral $\mathrm{V}(\mathrm{III})$ species from their $\mathrm{UV} /$ visible spectra and although X-ray structures are not available, analysis of the d-d spectra suggests S-coordination is preferred to O-coordination in these complexes. ${ }^{69}$ This unexpected observation of the softer sulfur being preferred over the harder oxygen on a hard metal centre, is thought to be due to the ring strain in adjacent five-membered chelate rings with ether oxygen donors, whereas the longer 
$\mathrm{V}-\mathrm{S}$ and $\mathrm{C}-\mathrm{S}$ bonds to the larger sulfur relieves this strain. Statistical analysis of examples taken from a variety of crystal structures suggest $<\mathrm{S}-\mathrm{M}-\mathrm{S}$ in five-membered chelate rings on an octahedral metal centre are $\sim 82^{\circ}$, compared to $<\mathrm{O}-\mathrm{M}-\mathrm{O}$ of $\sim 75^{\circ} .{ }^{69}$ Complexes of open chain polydentates containing mixed neutral N/S donors are numerous, and have been explored in relation to vanadium in biological systems. ${ }^{13,70}$

\subsection{Niobium and tantalum}

The chemistries of the high oxidation states of niobium and tantalum with heavier group 16 donor ligands are very similar, although for direct analogues, those of tantalum are usually more stable, especially towards reduction.

\subsubsection{Niobium(V) and tantalum(V)}

The pentafluorides are very strong, hard Lewis acids, but dissolve readily in neat $\mathrm{Me}_{2} \mathrm{~S}_{\text {or }} \mathrm{Et}_{2} \mathrm{~S}$ to give extremely moisture sensitive colourless crystals $(\mathrm{R}=\mathrm{Me})$ or oils $(\mathrm{R}=\mathrm{Et})$ of $\left[\mathrm{MF}_{5}\left(\mathrm{R}_{2} \mathrm{~S}\right)\right](\mathrm{Scheme}$ $3) .^{71,72}$

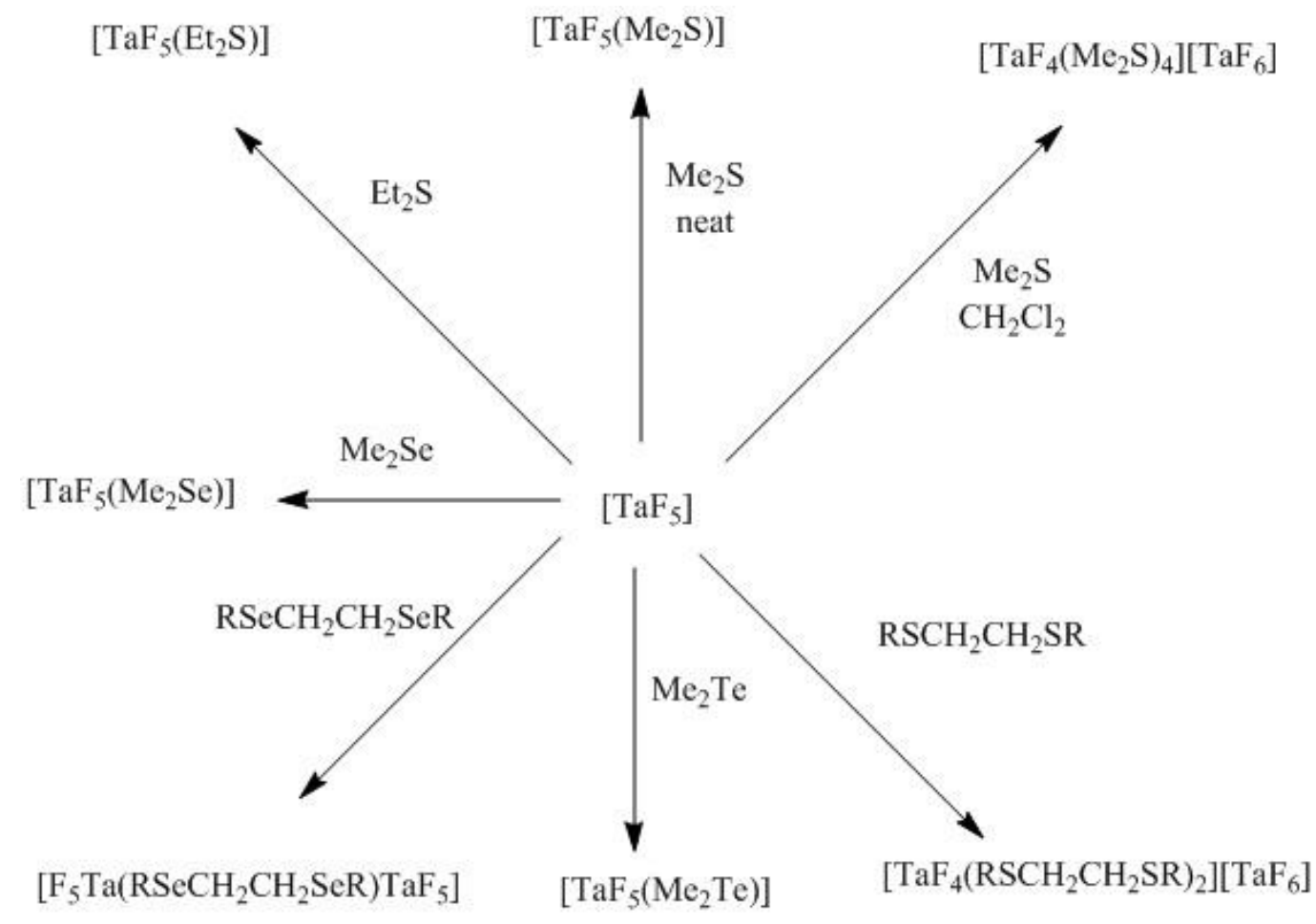

\section{Scheme 3. Tantalum( $(V)$ fluoride complexes of chalcogenoethers}

Multinuclear NMR $\left({ }^{1} \mathrm{H},{ }^{19} \mathrm{~F}\right.$ and $\left.{ }^{93} \mathrm{Nb}\right)$ spectroscopy shows reversible dissociation of the $\mathrm{R}_{2} \mathrm{~S}$ in solution in anhydrous $\mathrm{CH}_{2} \mathrm{Cl}_{2}$ at ambient temperatures, but at $200 \mathrm{~K}$ exchange has slowed and the two resonances expected for the square pyramidal $\mathrm{MF}_{5}$ unit are observed in the ${ }^{19} \mathrm{~F}$ NMR spectra. The pale yellow $\left[\mathrm{MF}_{5}\left(\mathrm{Me}_{2} \mathrm{Se}\right)\right]$ were made similarly, but are less stable and decompose in the solid state in just a few days, with fluorination of the $\mathrm{Me}_{2} \mathrm{Se}^{71.72}$ More surprisingly, it is possible to isolate an unstable yellow solid from reaction of $\mathrm{TaF}_{5}$ with $\mathrm{Me}_{2} \mathrm{Te}$ in $\mathrm{CH}_{2} \mathrm{Cl}_{2}$ solution at $273 \mathrm{~K}$, which was identified 
spectroscopically as $\left[\mathrm{TaF}_{5}\left(\mathrm{Me}_{2} \mathrm{Te}\right)\right] \cdot{ }^{73}$ The complex decomposes within a few hours and ${ }^{19} \mathrm{~F}$ NMR spectroscopy identified $\mathrm{Me}_{2} \mathrm{TeF}_{2}$ and $\left[\mathrm{Ta}_{2} \mathrm{~F}_{11}\right]^{-}$among the decomposition products. In contrast, reaction of $\mathrm{NbF}_{5}$ and $\mathrm{Me}_{2} \mathrm{Te}$ in $\mathrm{CH}_{2} \mathrm{Cl}_{2}$ solution immediately produced a black tar. ${ }^{71}$ Solutions of excess $\mathrm{Me}_{2} \mathrm{~S}$ with either group 5 pentafluoride in $\mathrm{CH}_{2} \mathrm{Cl}_{2}$ solution, refrigerated for several days, deposit extremely moisture sensitive, colourless crystals of $\left[\mathrm{MF}_{4}\left(\mathrm{Me}_{2} \mathrm{~S}\right)_{4}\right]\left[\mathrm{MF}_{6}\right]$. The crystal structures show the familiar octahedral anions and eight-coordinate cations with a distorted dodecahedral geometry (Fig. 28). ${ }^{71,72}$ There is NMR spectroscopic evidence for the formation of $\left[\mathrm{TaF}_{4}\left(\mathrm{Et}_{2} \mathrm{~S}\right)_{4}\right]\left[\mathrm{TaF}_{6}\right]$ in solution at low temperatures, but it could not be isolated, and similar complexes do not form with $\mathrm{Me}_{2} \mathrm{Se}$. $\left[\mathrm{NbF}_{4}(\mathrm{tht})_{2}\right]\left[\mathrm{NbF}_{6}\right]$ is also known. ${ }^{73}$

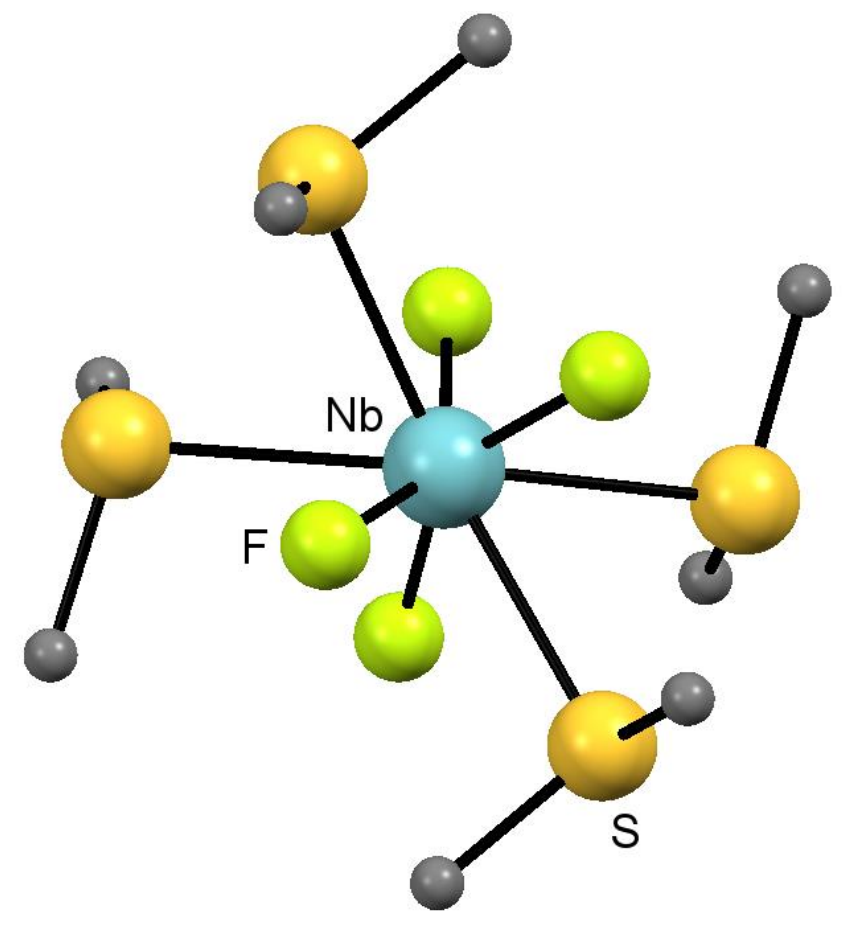

Figure 28. The $\left[\mathrm{NbF}_{4}\left(\mathrm{Me}_{2} \mathrm{~S}\right)_{4}\right]^{+}$cation redrawn from Reference 71.

The $\left[\mathrm{MX}_{5} \mathrm{~L}\right]\left(\mathrm{X}=\mathrm{Cl}, \mathrm{Br} ; \mathrm{L}=\mathrm{Me}_{2} \mathrm{~S}, \mathrm{Et}_{2} \mathrm{~S},{ }^{\mathrm{n}} \mathrm{Bu}_{2} \mathrm{~S}, \mathrm{Me}_{2} \mathrm{Se},{ }^{\mathrm{n}} \mathrm{Bu} \mathrm{u}_{2} \mathrm{Se}\right.$, etc. $)$ have long been known and the distorted octahedral geometry has been established crystallographically for $\left[\operatorname{NbBr}_{5}\left(\mathrm{Me}_{2} \mathrm{~S}\right)\right]$, $\left[\mathrm{NbCl}_{5}\left(\mathrm{Me}_{2} \mathrm{Se}\right)\right]$ and $\left[\mathrm{TaCl}_{5}\left(\mathrm{Me}_{2} \mathrm{Se}\right)\right]{ }^{71,73}$ The complexes range in colour from pale yellow $\left[\mathrm{TaCl}_{5}\left(\mathrm{Me}_{2} \mathrm{~S}\right)\right]$ through to dark red $\left[\mathrm{NbBr}_{5}\left(\mathrm{Me}_{2} \mathrm{Se}\right)\right]$ and all are very moisture sensitive, although less so than the corresponding fluorides. Detailed spectroscopic (UV/visible, IR, ${ }^{1} \mathrm{H},{ }^{93} \mathrm{Nb},{ }^{77} \mathrm{Se} \mathrm{NMR}$ ) data have been reported, and notably, there is no evidence for $\left[\mathrm{MX}_{4}\left(\mathrm{R}_{2} \mathrm{E}\right)_{4}\right]^{+}$cations analogous to the fluorides. ${ }^{71-73}$ Unstable $\left[\mathrm{NbCl}_{5}\left(\mathrm{Me}_{2} \mathrm{Te}\right)\right],{ }^{71}$ and the rather more stable $\left[\mathrm{TaX}_{5}\left(\mathrm{Me}_{2} \mathrm{Te}\right)\right](\mathrm{X}=\mathrm{Cl}$ or $\mathrm{Br})$ and $\left[\mathrm{TaCl}_{5}\left({ }^{\mathrm{n} B u_{2} \mathrm{Te}}\right)\right]$ have been isolated and characterised. ${ }^{73}$ The structure of $\left[\mathrm{TaCl}_{5}\left(\mathrm{Me}_{2} \mathrm{Te}\right)\right]$ (Fig. 29) confirms the identity, and contains the highest oxidation state of any metal in a structurally authenticated telluroether complex. ${ }^{73}$ 


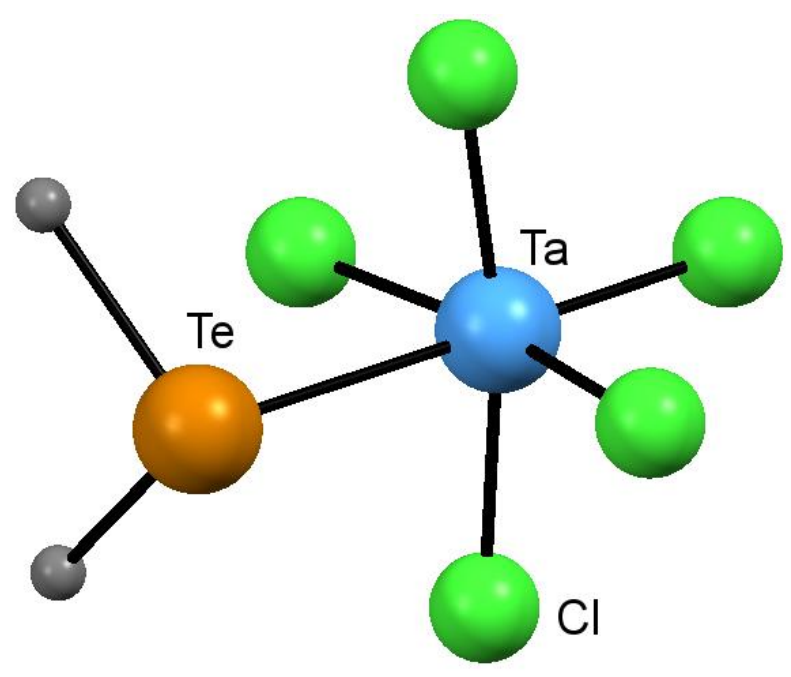

Figure 29. The structure of $\left[\mathrm{TaCl}_{5}\left(\mathrm{Me}_{2} \mathrm{Te}\right)\right]$ redrawn from Reference 73.

While the tantalum complexes proved to be unsuitable as CVD reagents, the $\left[\mathrm{NbCl}_{5}\left({ }^{n} \mathrm{Bu}_{2} \mathrm{~S}\right)\right]$ and $\left[\mathrm{NbCl}_{5}\left({ }^{n} \mathrm{Bu}_{2} \mathrm{Se}\right)\right]$ serve as single source precursors for the LPCVD of crystalline, reflective brown-black $\mathrm{NbS}_{2}$ and $\mathrm{NbSe}_{2}$ thin films at $750{ }^{\circ} \mathrm{C}$ and $650{ }^{\circ} \mathrm{C}$, respectively (Fig. 30). Grazing incidence and in-plane X-ray diffraction data confirm that both materials adopt the 3R-polytype $(\mathrm{R} 3 \mathrm{mh})$, and the sulfide shows preferred orientation with the crystallites aligned predominantly with the $c$ axis perpendicular to the substrate. This is also a rare example of CVD from a metal-thioether complex. ${ }^{73}$

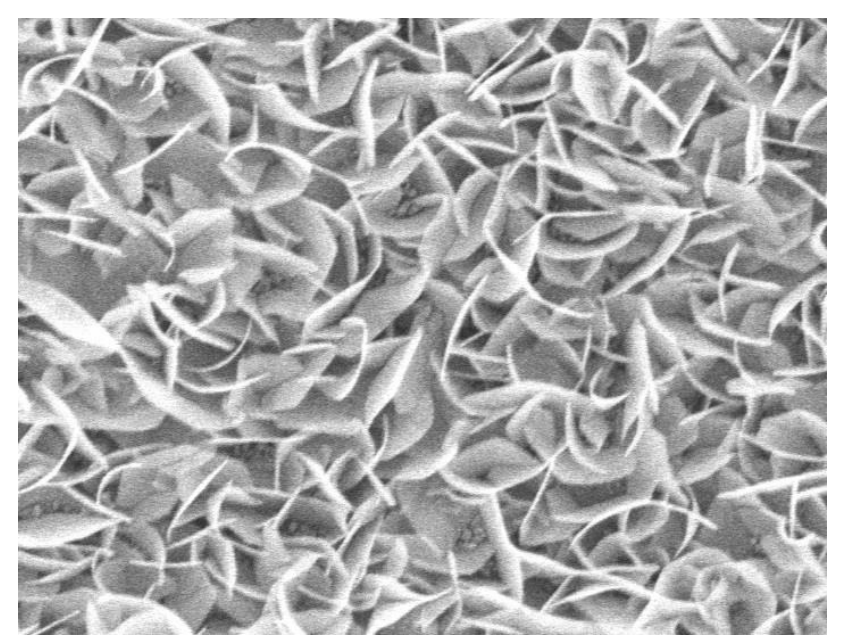

Figure 30. Scanning electron micrograph showing one of the $\mathrm{NbSe}_{2}$ thin films deposited by LPCVD from $\left[\mathrm{NbCl}_{5}\left({ }^{n} \mathrm{Bu}_{2} \mathrm{Se}\right)\right]$ onto $\mathrm{SiO}_{2}$ at $6^{600^{\circ}} \mathrm{C}$, from Reference 73.

The reaction of the dithioethers $\mathrm{RS}\left(\mathrm{CH}_{2}\right)_{2} \mathrm{SR}\left(\mathrm{R}=\mathrm{Me}\right.$, Et, $\left.{ }^{\mathrm{i} r}\right)$ with the pentafluorides in anhydrous $\mathrm{CH}_{2} \mathrm{Cl}_{2}$ solution produces $\left[\mathrm{MF}_{4}\left\{\mathrm{RS}\left(\mathrm{CH}_{2}\right)_{2} \mathrm{SR}\right\}_{2}\right]\left[\mathrm{MF}_{6}\right] \cdot{ }^{71,72}$ The X-ray structure of $\left[\mathrm{NbF}_{4}\left\{{ }^{\mathrm{i} P S S}\left(\mathrm{CH}_{2}\right)_{2} \mathrm{~S} \operatorname{Pr}\right\}_{2}\right]\left[\mathrm{NbF}_{6}\right]$ shows the chelating dithioethers in the meso-form, but both 
$\left[\mathrm{MF}_{4}\left\{\mathrm{MeS}\left(\mathrm{CH}_{2}\right)_{2} \mathrm{SMe}\right\}_{2}\right]\left[\mathrm{MF}_{6}\right]$ contain $D L$ forms of the dithioethers, with the two cations in the asymmetric unit exhibiting SSSS and SSRR stereochemistry respectively (Fig.31) .
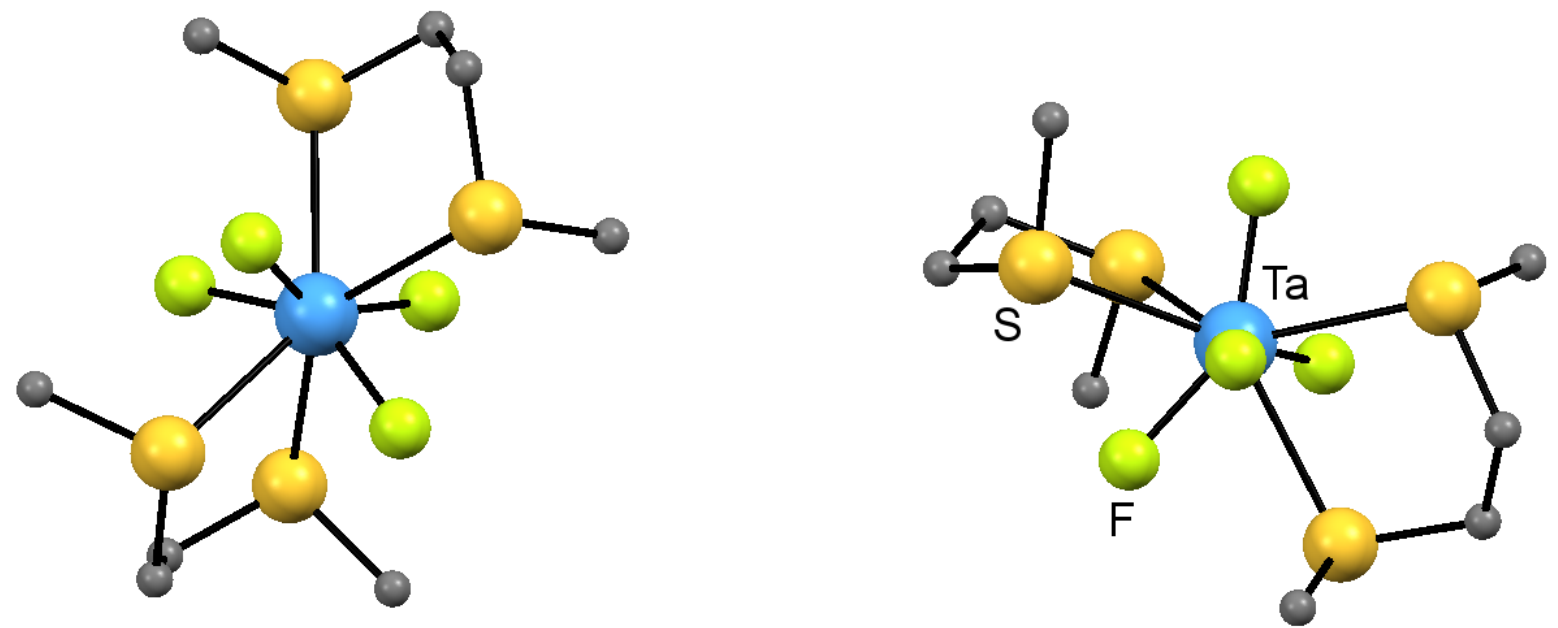

Figure 31. The two different cations present in the unit cell of $\left[\mathrm{TaF}_{4}\left\{\mathrm{MeS}\left(\mathrm{CH}_{2}\right)_{2} \mathrm{SMe}\right\}_{2}\right]\left[\mathrm{TaF}_{6}\right]$ redrawn from Reference 72.

The dithioether $o-\mathrm{C}_{6} \mathrm{H}_{4}\left(\mathrm{CH}_{2} \mathrm{SMe}\right)_{2}$ also forms eight coordinate cations, but rather than produce sevenmembered chelate rings, it bridges between $\mathrm{Nb}(\mathrm{V})$ centres to produce a chain polymer (Fig. 32) ${ }^{75}$

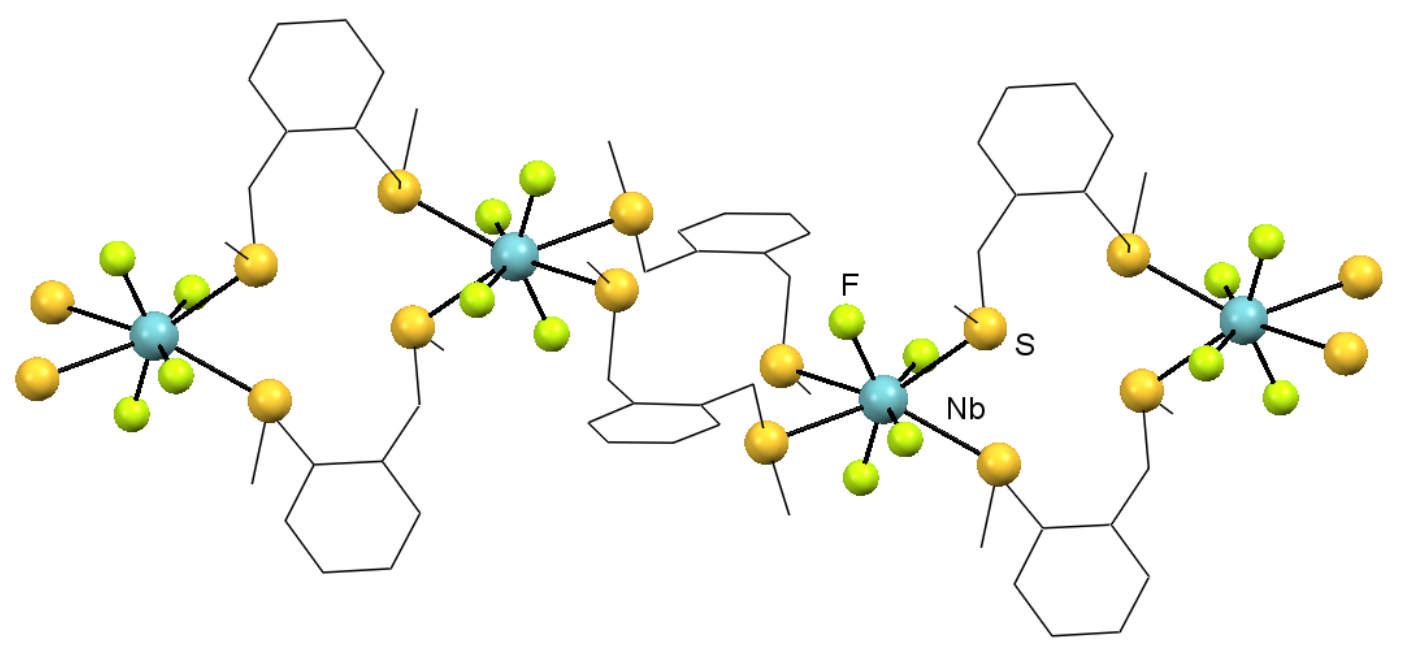

Figure 32. Part of the polymeric cation chain in $\left[\mathrm{NbF}_{4}\left\{0-\mathrm{C}_{6} \mathrm{H}_{4}\left(\mathrm{CH}_{2} \mathrm{SMe}\right)_{2}\right\}_{2}\right]^{+}$redrawn from Reference 75.

Very unusual crystalline sulfonium salts were produced as minor by-products of the reactions of $\mathrm{NbF}_{5}$ with $o-\mathrm{C}_{6} \mathrm{H}_{4}\left(\mathrm{CH}_{2} \mathrm{SMe}\right)_{2}$ and [9]aneS $\mathrm{S}_{3}$ in dilute $\mathrm{CH}_{2} \mathrm{Cl}_{2}$ solution, refrigerated for several weeks. ${ }^{75}$ The successful syntheses of these sulfonium salts probably results from the rigorously anhydrous conditions and the large, very weakly coordinating fluoro-anions present. Crystal structures of both were determined; Fig. 33 shows the structure of $\left[\left([9] \mathrm{aneS}_{3}\right) \mathrm{H}\right]\left[\mathrm{NbF}_{6}\right]$ in which the proton is bonded to one sulfur $(1.19 \AA)$ and interacts weakly with the other two $(2.50$ and $2.51 \AA)$ and with the macrocycle 
conformation significantly different from that in [9]aneS $\mathrm{S}_{3}$ itself. $\left[\left\{o-\mathrm{C}_{6} \mathrm{H}_{4}\left(\mathrm{CH}_{2} \mathrm{SMe}\right)_{2}\right\} \mathrm{H}\right]^{+}$has similar $\mathrm{S}-\mathrm{H}$ and $\mathrm{S} \cdots \mathrm{H}$ interactions.
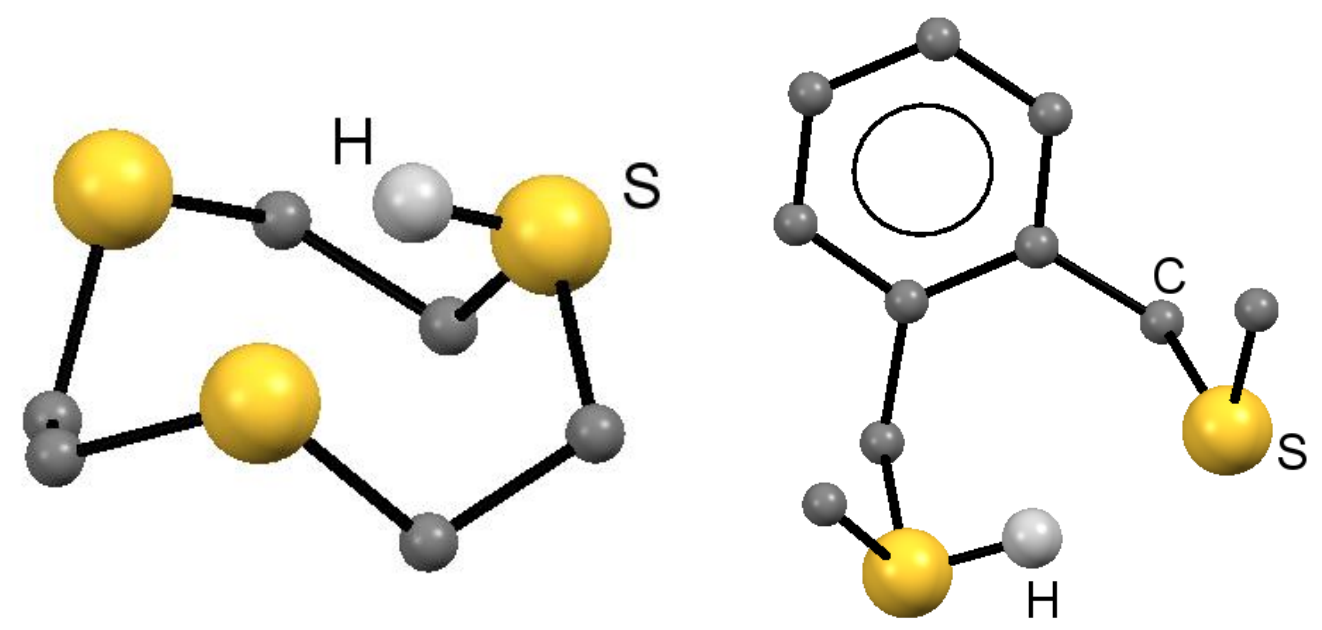

Figure 33. The sulfonium cations in $\left[\left([9] \mathrm{aneS}_{3}\right) \mathrm{H}\right]\left[\mathrm{NbF}_{6}\right]$ (left) and $\left[\left\{o-\mathrm{C}_{6} \mathrm{H}_{4}\left(\mathrm{CH}_{2} \mathrm{SMe}\right)_{2}\right\} \mathrm{H}\right]\left[\mathrm{NbF}_{6}\right]$ (right) redrawn from Reference 75.

In contrast to the dithioethers, diselenoethers form ligand-bridged dimers $\left[\left(\mathrm{MF}_{5}\right)_{2}\left\{\mu-\mathrm{RSe}\left(\mathrm{CH}_{2}\right)_{2} \mathrm{SeR}\right\}\right]$ $\left(\mathrm{R}=\mathrm{Me},{ }^{\mathrm{n}} \mathrm{Bu}\right.$ ) when reacted with $\mathrm{MF}_{5}$ in a 1:2 molar ratio in $\mathrm{CH}_{2} \mathrm{Cl}_{2}$; rapid decomposition occurs when excess diselenoether is present. ${ }^{71,72}$ Most dithioethers and diselenoethers react with the heavier $\mathrm{MX}_{5}(\mathrm{X}=\mathrm{Cl}$ or $\mathrm{Br})$ to form ligand-bridged dimers, $\left[\left(\mathrm{MX}_{5}\right)_{2}\left\{\mu-\mathrm{RE}\left(\mathrm{CH}_{2}\right)_{2} \mathrm{ER}\right\}\right]$, although 2,5dithiahexane, uniquely, produces the eight-coordinate cation salts, $\left[\mathrm{MX}_{4}\left\{\mathrm{MeS}\left(\mathrm{CH}_{2}\right)_{2} \mathrm{SMe}\right\}_{2}\right][\mathrm{MX} 6]^{71,72}$ Crystal structures have been determined for five examples; $\left[\left(\mathrm{MCl}_{5}\right)_{2}\left\{\mu-\mathrm{MeSe}\left(\mathrm{CH}_{2}\right)_{2} \mathrm{SeMe}\right\}\right], \quad\left[\left(\mathrm{NbCl}_{5}\right)_{2}\left\{\mu-o-\mathrm{C}_{6} \mathrm{H}_{4}\left(\mathrm{CH}_{2} \mathrm{SMe}\right)_{2}\right\}\right] \quad$ and $\quad\left[\left(\mathrm{MCl}_{5}\right)_{2}\{\mu-o-\right.$ $\left.\left.\mathrm{C}_{6} \mathrm{H}_{4}\left(\mathrm{CH}_{2} \mathrm{SEt}\right)_{2}\right\}\right]{ }^{71-73}$ Ditelluroethers often experience Te-C bond fission in related reactions. ${ }^{73}$

There are no recent reports of attempts to explore the chemistry of the metal halides with thiamacrocycles, and the only examples remain the long-known $\left[\left(\mathrm{NbCl}_{5}\right)_{2}\left(\mu-\kappa^{2}\right.\right.$-thiacrown $\left.)\right]$ which have exodentate coordinated thia-crown. ${ }^{10}$ In contrast to vanadium, complexes with oxide-halides of the heavier metals have been little studied of late. Two complexes of $\mathrm{NbOCl}_{3}$, green $\left[\mathrm{NbOCl}_{3}\left(\mathrm{Me}_{2} \mathrm{~S}\right)\right]$ and $\left[\mathrm{NbOCl}_{3}\left\{\mathrm{MeS}\left(\mathrm{CH}_{2}\right)_{2} \mathrm{SMe}\right\}\right]$, were obtained 'accidently' by air oxidation/hydrolysis of mixtures of the ligands and $\mathrm{NbCl}_{4}$ in $\mathrm{CH}_{2} \mathrm{Cl}_{2}$ solution. ${ }^{76}$ The latter has the expected octahedral structure with $\mathrm{O}_{\text {trans } \mathrm{S} \text {, }}$ but the $\left[\mathrm{NbOCl}_{3}\left(\mathrm{Me}_{2} \mathrm{~S}\right)\right]$ contains square pyramidal units with an apical oxo-group, linked into chains by very asymmetric oxido-bridges $\left(1.74,2.22 \AA\right.$ ) (Fig. 34). In contrast, hydrolysis of $\left[\left(\mathrm{TaCl}_{5}\right)_{2}\{\mu\right.$ $\left.\left.{ }^{i} \mathrm{PrS}\left(\mathrm{CH}_{2}\right){ }_{2}{ }^{\mathrm{i}} \mathrm{Pr}\right\}\right]$ formed the dimer $\left[\mathrm{Cl}_{5} \mathrm{Ta}(\mu-\mathrm{O}) \mathrm{TaCl}_{3}\left\{{ }^{\mathrm{i}} \mathrm{PrS}\left(\mathrm{CH}_{2}\right)_{2}{ }^{\mathrm{i}} \mathrm{Pr}\right\}\right]$ (Fig. 35). ${ }^{77}$ Although $\mathrm{NbOF}_{3}$ forms complexes with some $\mathrm{N}$ - and $\mathrm{O}$-donor neutral ligands, attempts to prepare thioether complexes failed. ${ }^{78}$ 


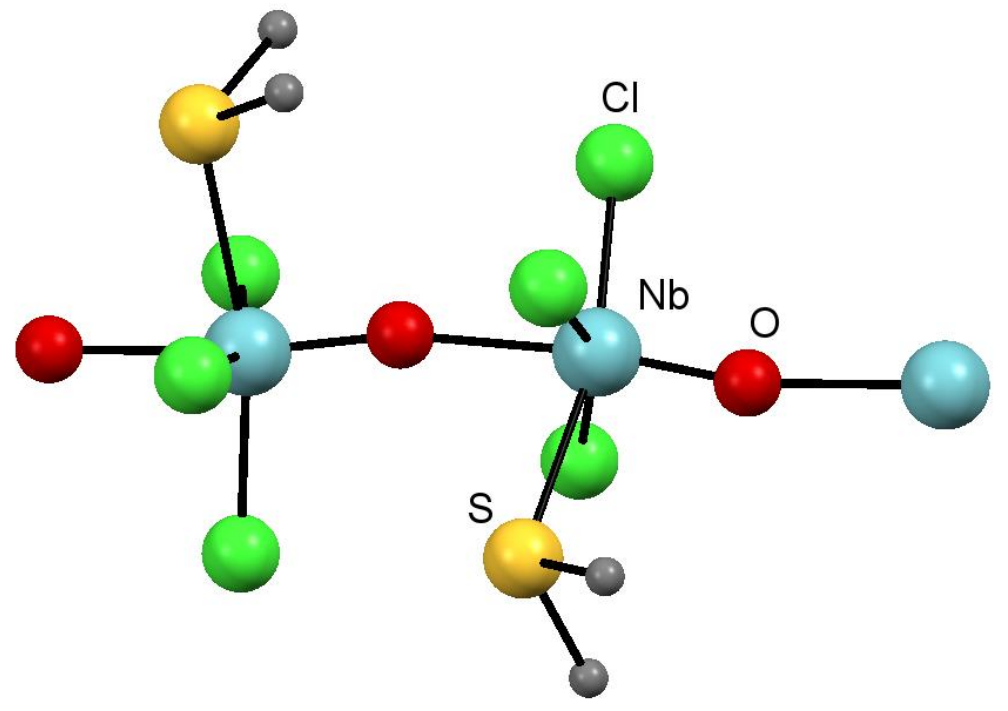

Figure 34. Part of the chain structure of $\left[\mathrm{NbOCl}_{3}\left(\mathrm{Me}_{2} \mathrm{~S}\right)\right]$ redrawn from Reference 76.

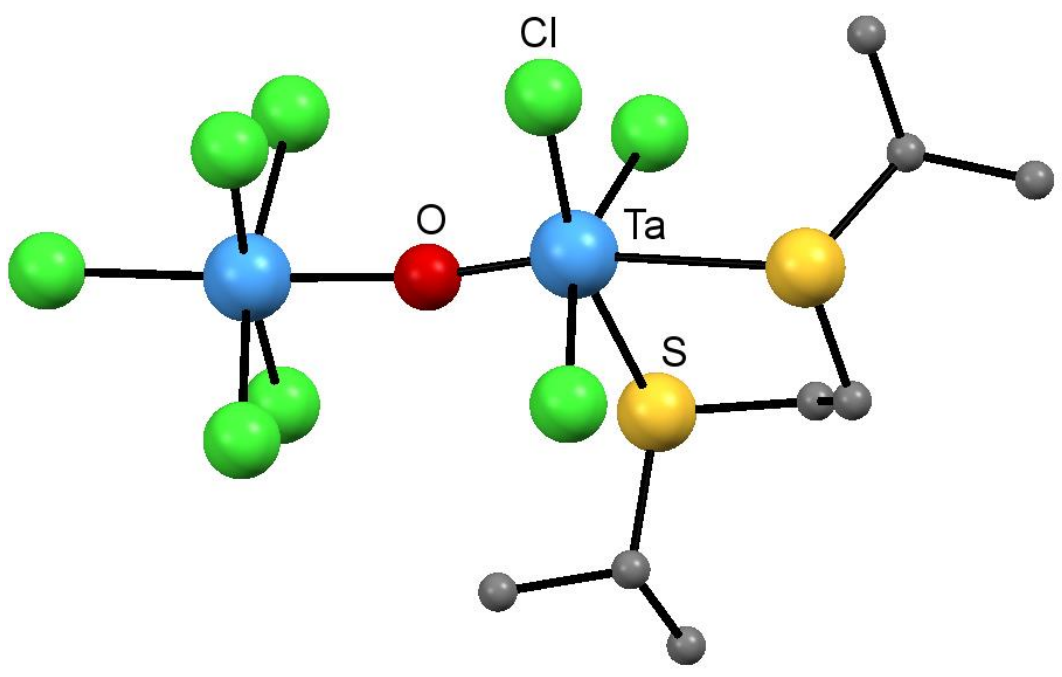

Figure 35. The structure of $\left[\mathrm{Cl}_{5} \mathrm{Ta}(\mu-\mathrm{O}) \mathrm{TaCl}_{3}\left\{{ }^{\mathrm{i} P S}\left(\mathrm{CH}_{2}\right){ }_{2}^{\mathrm{i}} \mathrm{Pr}\right\}\right]$ redrawn from Reference 77.

\subsubsection{Niobium(IV and tantalum(IV)}

After an early study ${ }^{79}$ the chemistry of $\mathrm{Nb}(\mathrm{IV})$ halides with chalcogenoethers was largely neglected. Recent work $^{76}$ has shown that not only is the chemistry quite complicated, but the complexes are surprisingly unstable for a heavy metal and decompose/interconvert easily in solution. The reaction of $\mathrm{NbCl}_{4}$ with excess $\mathrm{Me}_{2} \mathrm{~S}$ in $\mathrm{CH}_{2} \mathrm{Cl}_{2}$ produces a dark purple solid which appears to be cis$\left[\mathrm{NbCl}_{4}\left(\mathrm{Me}_{2} \mathrm{~S}\right)_{2}\right]$ on the basis of spectroscopic data, but this loses $\mathrm{Me}_{2} \mathrm{~S}$ very easily to form a diamagnetic yellow-brown $\left[\mathrm{NbCl}_{4}\left(\mathrm{Me}_{2} \mathrm{~S}\right)\right] \cdot{ }^{76}$ Use of $\left[\mathrm{NbX}_{4}(\mathrm{thf})_{2}\right]$ is unsatisfactory as the metal synthon because the hard thf ligands are not completely substituted by the chalcogenoether. The complexes, $\left[\mathrm{NbX}_{4}(\mathrm{tht})_{2}\right](\mathrm{X}=\mathrm{Cl}, \mathrm{Br}, \mathrm{I})$ and $\left[\mathrm{NbX}_{4}{ }^{\prime}\left(\mathrm{Me}_{2} \mathrm{~S}\right)_{2}\right]\left(\mathrm{X}^{\prime}=\mathrm{Br}\right.$ or I) were described many years ago and appear similar to $\left[\mathrm{NbCl}_{4}\left(\mathrm{Me}_{2} \mathrm{~S}\right)_{2}\right]$, but more stable. ${ }^{79}$ The crystal structure of $\left[\mathrm{NbCl}_{4}\left(\mathrm{Me}_{2} \mathrm{~S}\right)\right]$ reveals a dimer $\left[\mathrm{Nb}_{2} \mathrm{Cl}_{6}(\mu-\mathrm{Cl})_{2}\left(\mathrm{Me}_{2} \mathrm{~S}\right)_{2}\right]$, with a single $\mathrm{Nb}-\mathrm{Nb} \sigma$-bond (3.11 $\AA$ ) (Fig. 36) which accounts for its diamagnetism. 


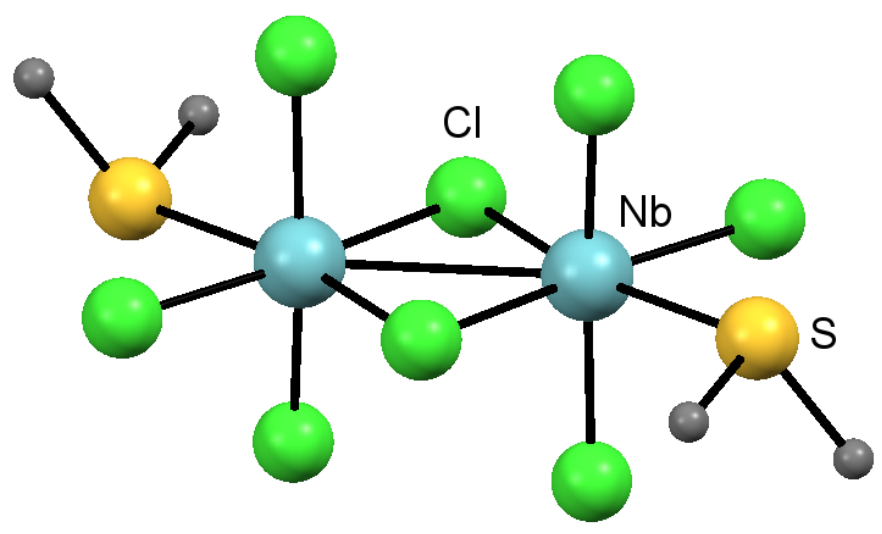

Figure 36. The structure of $\left[\mathrm{Nb}_{2} \mathrm{Cl}_{6}(\mu-\mathrm{Cl})_{2}\left(\mathrm{Me}_{2} \mathrm{~S}\right)_{2}\right]$ redrawn from Reference 76.

The $\left[\mathrm{NbCl}_{4}\left(\mathrm{R}_{2} \mathrm{Se}\right)_{2}\right] \quad\left(\mathrm{R}=\mathrm{Me}\right.$ or $\left.{ }^{\mathrm{n}} \mathrm{Bu}\right)$ are more stable to ligand loss, although decomposition of a $\mathrm{CH}_{2} \mathrm{Cl}_{2}$ solution of $\left[\mathrm{NbCl}_{4}\left(\mathrm{Me}_{2} \mathrm{Se}\right)_{2}\right]$ gave crystals of $\left[\mathrm{Nb}_{2} \mathrm{Cl}_{6}(\mu-\mathrm{Cl})_{2}\left(\mathrm{Me}_{2} \mathrm{Se}\right)_{2}\right]$. Most unexpectedly, the 1:2 dimethyltelluride complex proved to be a dinuclear species, $\left[\mathrm{Nb}_{2} \mathrm{Cl}{ }_{4}(\mu-\mathrm{Cl})_{4}\left(\mathrm{Me}_{2} \mathrm{Te}\right)_{4}\right]$, with eightcoordinate niobium (Fig. 37). ${ }^{76}$ All the $\mathrm{R}_{2} \mathrm{E}$ complexes seem to partially dissociate ligand in $\mathrm{CH}_{2} \mathrm{Cl}_{2}$ solution.

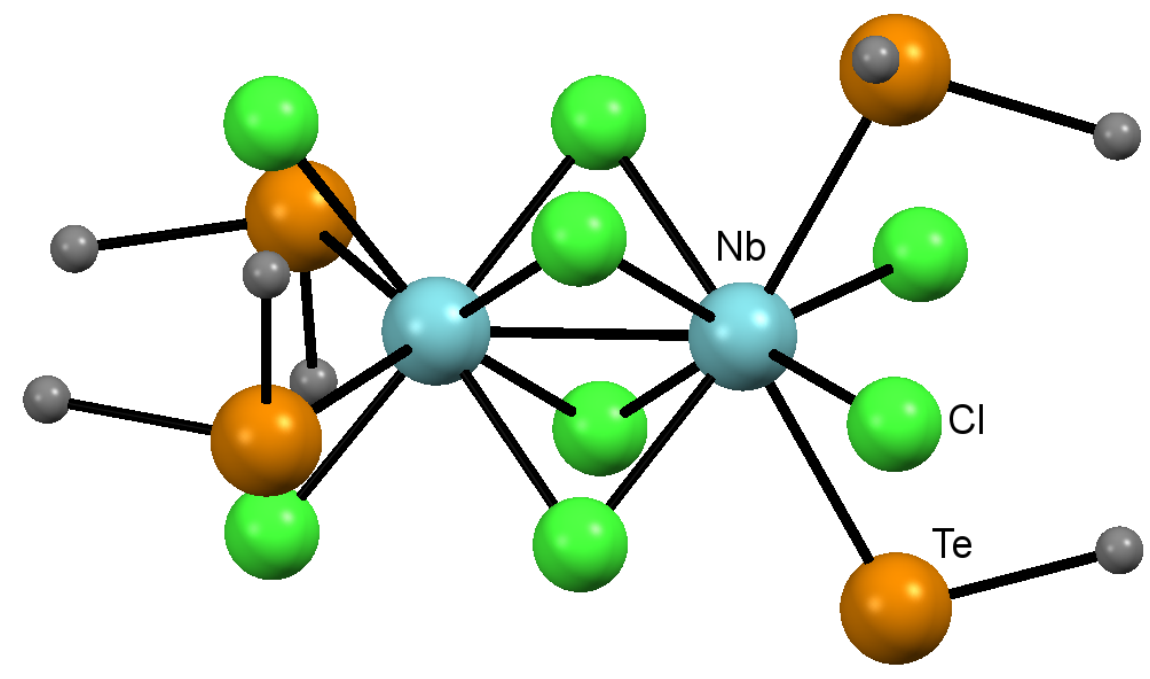

Figure 37. The structure of $\left[\mathrm{Nb}_{2} \mathrm{Cl}_{4}(\mu-\mathrm{Cl})_{4}\left(\mathrm{Me}_{2} \mathrm{Te}\right)_{4}\right]$ redrawn from Reference 76.

Orange $\left[\mathrm{Ta}_{2} \mathrm{Cl}_{6}(\mu-\mathrm{Cl})_{2}\left(\mathrm{Me}_{2} \mathrm{~S}\right)_{2}\right]$ was obtained as a by-product from the $\mathrm{Mg}$ reduction of a $\mathrm{TaCl}_{5}-\mathrm{Me}_{2} \mathrm{~S}$ mixture in toluene. ${ }^{80}$

Dithio- and diseleno-ethers mostly form six-coordinate $\left[\mathrm{NbCl}_{4}(\mathrm{~L}-\mathrm{L})\right]\left(\mathrm{L}-\mathrm{L}=\mathrm{MeS}\left(\mathrm{CH}_{2}\right)_{3} \mathrm{SMe}\right.$, ${ }^{i} \mathrm{PrS}\left(\mathrm{CH}_{2}\right)_{2} \mathrm{~S} \mathrm{Pr}, \quad o-\mathrm{C}_{6} \mathrm{H}_{4}\left(\mathrm{CH}_{2} \mathrm{SEt}\right)_{2}, \operatorname{MeSe}\left(\mathrm{CH}_{2}\right)_{n} \mathrm{SeMe}\left(\mathrm{n}=2\right.$ or 3) and ${ }^{\mathrm{n}} \mathrm{BuSe}\left(\mathrm{CH}_{2}\right)_{3} \mathrm{Se}{ }^{\mathrm{n}} \mathrm{Bu}$ ), but $\mathrm{MeS}\left(\mathrm{CH}_{2}\right)_{2} \mathrm{SMe}$ forms both six- and eight-coordinate complexes depending on the reaction conditions (Fig. 38). ${ }^{76}$ 

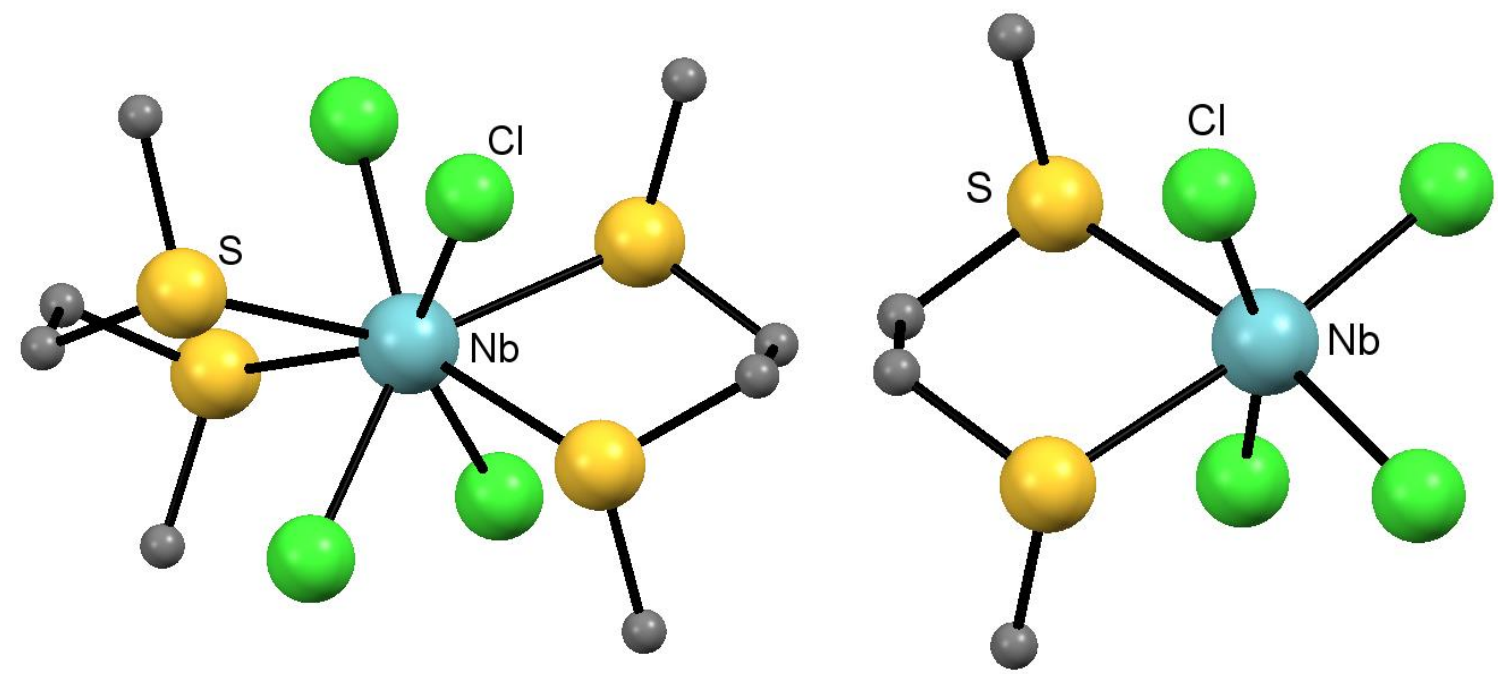

Figure 38. The structures of the eight-coordinate $\left[\mathrm{NbCl}_{4}\left\{\mathrm{MeS}\left(\mathrm{CH}_{2}\right)_{2} \mathrm{SMe}_{2}\right]\right.$ (left) and the sixcoordinate $\left[\mathrm{NbCl}_{4}\left\{\mathrm{MeS}\left(\mathrm{CH}_{2}\right)_{2} \mathrm{SMe}\right\}\right]$ (right). Redrawn from Reference 76.

As first recognised by Cotton, ${ }^{81}$ the easy fragmentation of $\mathrm{C}-\mathrm{E}$ groups brings an added complexity to this area of coordination chemistry, with some (but by no means all) early reports of $\mathrm{Nb}_{2}{ }_{2}$ or $\mathrm{Ta}_{2}{ }^{\mathrm{III}}$ dimers of type $\left[\mathrm{M}_{2} \mathrm{Cl} l_{4}(\mu-\mathrm{Cl})_{2}\left\{\mathrm{RS}\left(\mathrm{CH}_{2}\right)_{n} \mathrm{SR}\right\}_{2}\right]$, turning out in reality to be the $\mathrm{Nb}^{\mathrm{IV}}{ }_{2}$ or $\mathrm{Ta}^{\mathrm{IV}}{ }_{2}$ dimers, $\left[\mathrm{M}_{2} \mathrm{Cl}_{4}(\mu-\mathrm{S})_{2}\left\{\mathrm{RS}\left(\mathrm{CH}_{2}\right)_{n} \mathrm{SR}\right\}_{2}\right]$. The origin of the incorrect assignment of the formula is that the isoelectronic $\mathrm{Cl}^{-}$and $\mathrm{S}^{2-}$ are indistinguishable by X-ray methods, and distinction of the two types instead comes from careful consideration of the $\mathrm{M}-\mathrm{M}$ bond lengths, i.e. the double bonds in the $\mathrm{M}_{2}^{\mathrm{III}}$ dimers are significantly shorter than the single bonds in the $\mathrm{M}^{\mathrm{IV}}{ }_{2}$ species. Both families of complexes form under similar conditions and in some cases both chloride and sulfide bridged species may be present in the same synthesis. A recent example of this is the yellow-brown $\left[\mathrm{Nb}_{2} \mathrm{Cl}_{4}(\mu-\right.$ $\left.\mathrm{S})_{2}\left\{\mathrm{MeS}\left(\mathrm{CH}_{2}\right)_{3} \mathrm{SMe}\right\}_{2}\right]$ (Fig. 39) obtained as a minor by-product from the synthesis of the red $\left[\mathrm{Nb}_{2} \mathrm{Cl}_{4}(\mu-\mathrm{Cl})_{2}\left\{\mathrm{MeS}\left(\mathrm{CH}_{2}\right)_{3} \mathrm{SMe}\right\}_{2}\right]{ }^{76} \quad$ Fragmentation of $\mathrm{C}-\mathrm{Se}$ bonds is both easier (and more easily identified crystallographically) and is exemplified by the formation of orange crystals of $\left[\mathrm{Ta}_{2} \mathrm{Cl}_{4}(\mu-\right.$ $\left.\mathrm{Se})_{2}\left\{o-\mathrm{C}_{6} \mathrm{H}_{4}\left(\mathrm{CH}_{2} \mathrm{SeMe}\right)_{2}\right\}_{2}\right]$ (Fig 40), whilst from the same ligand and $\mathrm{NbCl}_{4}$ a major product contained coordinated 1,3-dihydro-benzo[c]selenophane $\left(o-\mathrm{C}_{6} \mathrm{H}_{4}\left(\mathrm{CH}_{2}\right)_{2} \mathrm{Se}\right)$ and two $\mu^{2}$-selenide bridges in $\left[\mathrm{Nb}_{2} \mathrm{Cl}_{4}(\mu-\mathrm{Se})_{2}\left\{o-\mathrm{C}_{6} \mathrm{H}_{4}\left(\mathrm{CH}_{2}\right)_{2} \mathrm{Se}\right\}_{4}\right]$ (Fig. 41). The extent of C-Se bond cleavage and the rearrangement of the selenoether in this system is notable. ${ }^{76}$ 


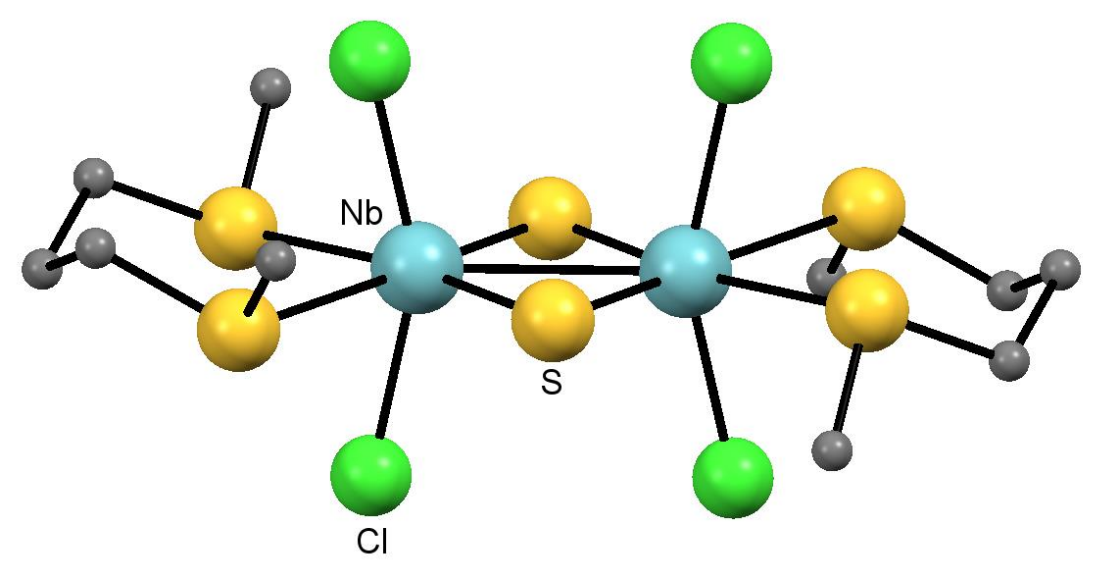

Figure 39. Structure of the by-product $\left[\mathrm{Nb}_{2} \mathrm{Cl}_{4}(\mu-\mathrm{S})_{2}\left\{\mathrm{MeS}\left(\mathrm{CH}_{2}\right)_{3} \mathrm{SMe}\right\}_{2}\right]$ redrawn from Reference 76.

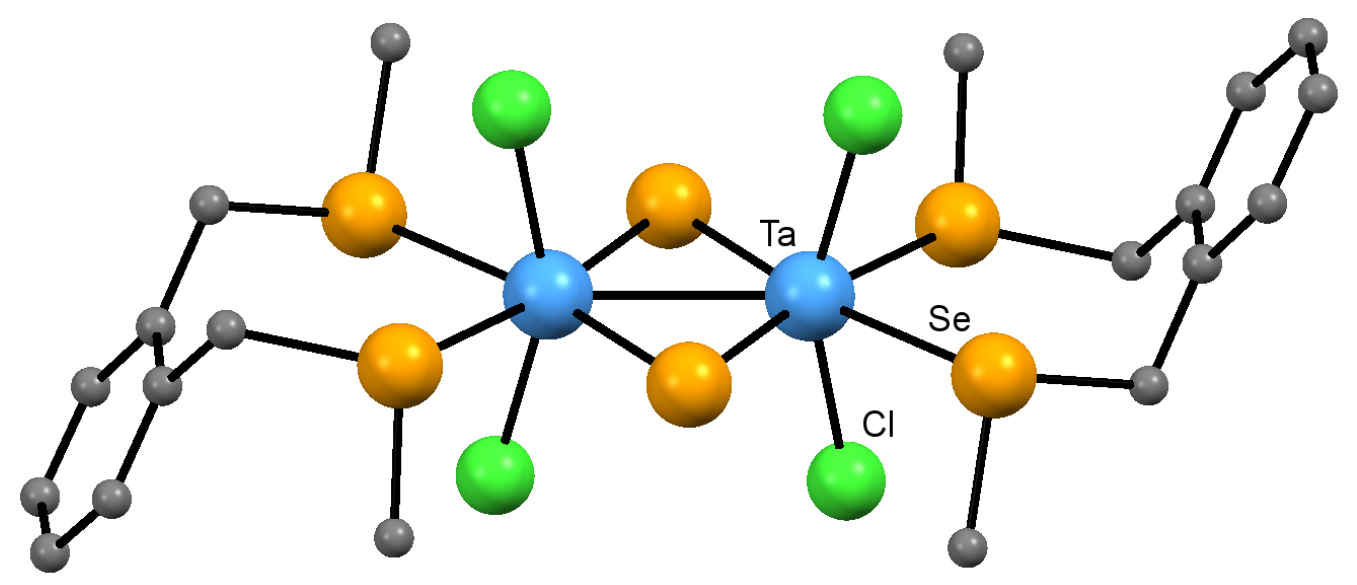

Figure 40. Structure of $\left[\mathrm{Ta}_{2} \mathrm{Cl}_{4}(\mu-\mathrm{Se})_{2}\left\{o-\mathrm{C}_{6} \mathrm{H}_{4}\left(\mathrm{CH}_{2} \mathrm{SeMe}\right)_{2}\right\}_{2}\right]$ redrawn from Reference 80.

\subsubsection{Niobium(III) and tantalum(III)}

There is an extensive and complex chemistry of thioethers with $\mathrm{Nb}(\mathrm{III})$ and $\mathrm{Ta}(\mathrm{III})$, including edgeand face-sharing octahedral dimers, which is too large to review here. ${ }^{13,80,82}$ Selenoether complexes have been reported more recently and include face-bridged $\left[\mathrm{M}_{2} \mathrm{Cl}_{4}\left(\mathrm{Me}_{2} \mathrm{Se}\right)_{4}(\mu-\mathrm{Cl})_{2}\left(\mu-\mathrm{Me}_{2} \mathrm{Se}\right)\right]$, and edge-bridged $\left[\mathrm{Nb}_{2} \mathrm{Cl}_{4}\left\{\mathrm{MeSe}\left(\mathrm{CH}_{2}\right)_{n} \mathrm{SeMe}\right\}_{2}(\mu-\mathrm{Cl})_{2}\right],\left[\mathrm{Ta}_{2} \mathrm{Cl}_{4}\left\{\mathrm{MeSe}\left(\mathrm{CH}_{2}\right)_{2} \mathrm{SeMe}\right\}_{2}(\mu-\mathrm{Cl})_{2}\right]$ species, as well as "dimers of dimers", for example, $\left[\left\{\mathrm{M}_{2} \mathrm{Cl}_{4}(\mu-\mathrm{Cl})_{2}\left(\mu-\mathrm{Me}_{2} \mathrm{~S}\right)\right\}_{2}\left\{\mu-\mathrm{MeSe}\left(\mathrm{CH}_{2}\right)_{3} \mathrm{SeMe}\right\}_{2}\right]^{80,83}$

Telluroether analogues have not been explored, although the ease of $\mathrm{C}-\mathrm{Te}$ bond fission is likely to complicate their syntheses. 


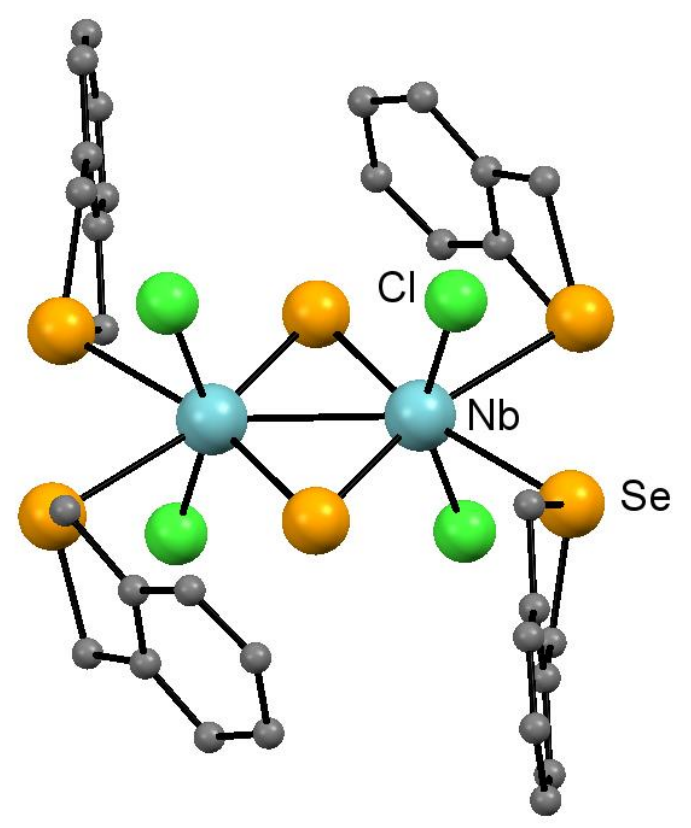

Figure 41. Structure of the rearrangement product $\left.\left[\mathrm{Nb}_{2} \mathrm{Cl}_{4}(\mu-\mathrm{Se})_{2}\left\{\mathrm{o}-\mathrm{C}_{6} \mathrm{H}_{4}\left(\mathrm{CH}_{2}\right)_{2} \mathrm{Se}\right)\right\}_{4}\right]$ redrawn from Reference 76.

\section{Group 6 metal $(\mathrm{Cr}$, Mo and $\mathrm{W})$ chalcogenoether complexes}

The chemistry in Group 6 is traditional d-block chemistry, the higher oxidation states are becoming relatively less stable, especially for the $3 \mathrm{~d}$ element $(\mathrm{Cr})$, and even in the $4 \mathrm{~d}$ and $5 \mathrm{~d}$ series the highest oxidation state complexes are readily reduced. The coverage below is deliberately very selective and intended to provide an overview for comparison with the previous groups. As a result of the paucity of examples in the higher oxidation states, the discussion focusses on $\mathrm{Cr}(\mathrm{III})$, whereas for the heavier elements, mainly focuses on the more extreme $\mathrm{M}(\mathrm{VI})$ oxidation state.

\subsection{Chromium}

The oxide chlorides, $\mathrm{CrO}_{2} \mathrm{Cl}_{2}$ and $\mathrm{CrOCl}_{3}$, are immediately reduced by thioethers, ${ }^{84}$ and the only high valent chromium complex appears to be the chromium(V) imido species, $\left[\mathrm{Cr}\left(\mathrm{N}^{\mathrm{t} B u}\right) \mathrm{Cl}_{2}\left([9] \mathrm{aneS}_{3}\right)\right]\left[\mathrm{CF}_{3} \mathrm{CO}_{2}\right]$, prepared from $\left[\mathrm{Cr}\left(\mathrm{N}^{t} \mathrm{Bu}\right) \mathrm{Cl}_{3}\left(\mathrm{MeOCH}_{2} \mathrm{CH}_{2} \mathrm{OMe}\right)\right]$, [9]aneS $\mathrm{S}_{3}$ and $\mathrm{Ag}\left[\mathrm{CF}_{3} \mathrm{CO}_{2}\right]$ which has the expected fac octahedral structure. ${ }^{85}$

The recent chemistry of chromium(III) complexes with group 16 ligands mostly involves macrocyclic derivatives, although the development of catalysts for selective oligomerisation/polymerisation based upon various facultative tridentate SNS-donor ligands has also stimulated work in this area. Complexes of two tridentate selenoethers, fac-[CrCl$\left.\left\{\mathrm{MeC}_{3}\left(\mathrm{CH}_{2} \mathrm{SeMe}\right)_{3}\right\}\right]$ and mer$\left[\mathrm{CrCl}_{3}\left\{\mathrm{Se}\left(\left(\mathrm{CH}_{2}\right)_{3} \mathrm{SeMe}\right)_{2}\right\}\right]$ have been prepared from $\left[\mathrm{CrCl}_{3}(\text { thf })_{3}\right]$ and the ligands in $\mathrm{CH}_{2} \mathrm{Cl}_{2}{ }^{86}$

A wide range of thia-macrocycles also react with $\left[\mathrm{CrCl}_{3}(\mathrm{thf})_{3}\right]$ or much less satisfactorily with $\mathrm{CrCl}_{3} \cdot 6 \mathrm{H}_{2} \mathrm{O}$, to form $\left[\mathrm{CrCl}_{3}\left(\kappa^{3}-\right.\right.$ macrocycle $\left.)\right]\left(\kappa^{3}-\right.$ macrocycle $=[9] \mathrm{aneS}_{3},[10] \mathrm{aneS}_{3},[11] \mathrm{aneS}_{3}$, $\left.[12] \mathrm{aneS}_{4},[15] \mathrm{aneS}_{5},[18] \mathrm{aneS}_{6},[20] \mathrm{aneS}_{6}\right)$ or $\left[\left(\mathrm{CrCl}_{3}\right)_{2}\left([18] \mathrm{ane} \mathrm{S}_{6}\right)\right]$, with even the higher denticity 
macrocycles failing to displace chloride from the precursor. Thus in each complex the macrocycle occupies three sites on one face of the octahedron. ${ }^{68,69,87}$ Several analogous complexes with $\mathrm{CrBr}_{3}$ have also been described. ${ }^{87}$ Analysis of the ligand field spectra show the macrocycles as weak donors to the hard trivalent chromium centre. Structural data on several of these complexes have been obtained by X-ray crystallography (Fig 42) and chromium k-edge EXAFS. ${ }^{68,69,87}$

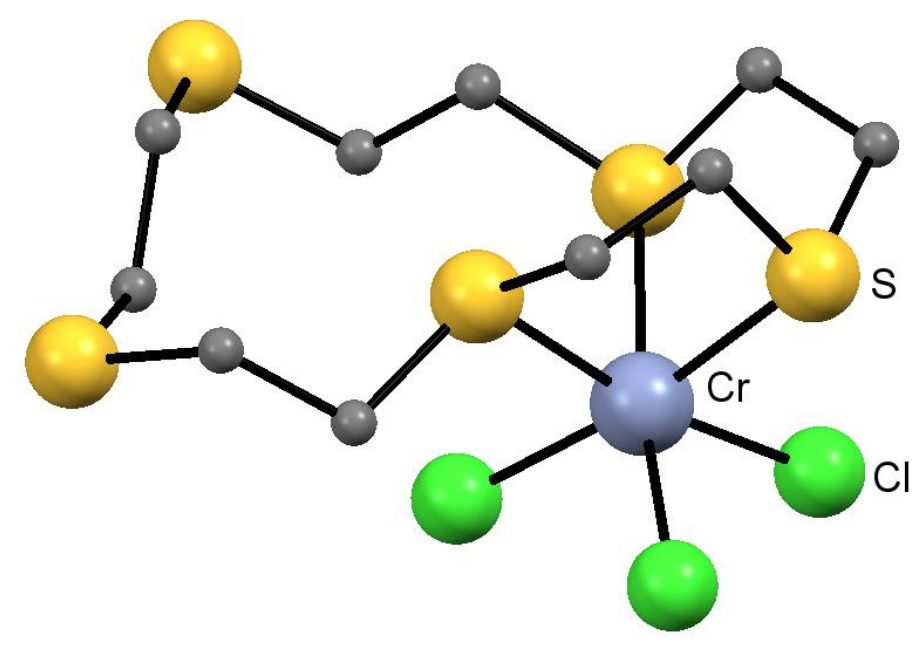

Figure 42. The structure of $\left[\mathrm{CrCl}_{3}\left(\kappa^{3}-[15] \mathrm{aneS}_{5}\right)\right]$, redrawn from Reference 69.

Although the neutral sulfur donors do not displace halides directly from the chromium(III) centre, removal of one halide using $\mathrm{Tl}\left[\mathrm{PF}_{6}\right],\left[\mathrm{CrX}_{3}(\mathrm{thf})_{3}\right](\mathrm{X}=\mathrm{Cl}$ or $\mathrm{Br})$ and the thiacrown (thiacrown $=$ [14]aneS $\mathrm{S}_{4}$ or $\left.[16] \mathrm{aneS}_{4}\right)$ in $\mathrm{MeNO}_{2}$ solution produces $\left[\mathrm{CrX}_{2}\right.$ (thia-crown)][ $\left.\mathrm{PF}_{6}\right]$, whilst $\left[\mathrm{CrI}_{2}(\right.$ thiacrown $\left.)\right]\left[\mathrm{PF}_{6}\right]$ were obtained from $\left[\mathrm{Cr}\left(\mathrm{thf}_{6}\right]\left[\mathrm{PF}_{6}\right]_{3},\left[\mathrm{Et}_{4} \mathrm{~N}\right] \mathrm{I}\right.$ and the thiacrown. ${ }^{87,88}$ The X-ray structures of $c i s-\left[\mathrm{CrX}_{2}\left([14] \mathrm{aneS}_{4}\right)\right] \mathrm{PF}_{6}(\mathrm{X}=\mathrm{Cl}$ or $\mathrm{Br})$ have been determined (Fig. 43). ${ }^{87,888}$

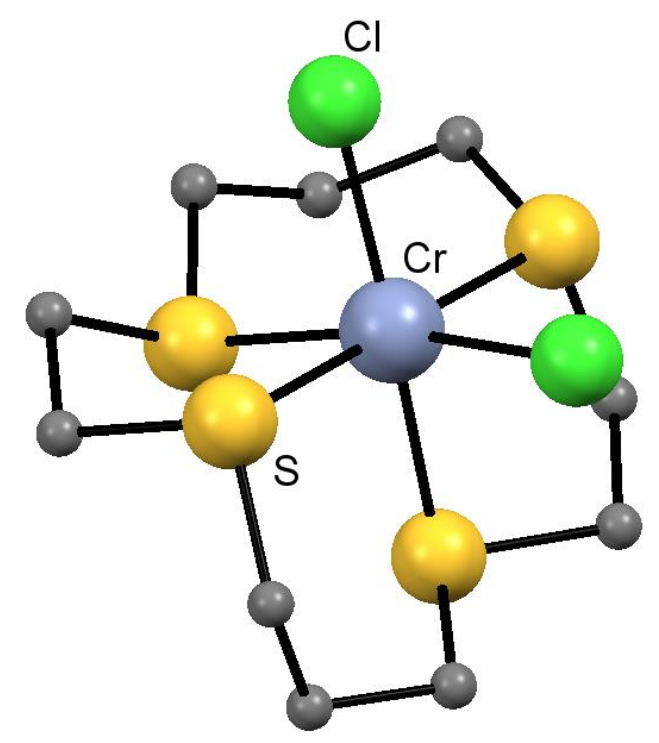

Figure 43. The structure of the cation in $c i s-\left[\mathrm{CrCl}_{2}\left([14] \mathrm{aneS}_{4}\right)\right] \mathrm{PF}_{6}$ redrawn from Reference 88.

A few complexes of mixed O/S-donor macrocycles, $\left[\mathrm{CrCl}_{3}\right.$ (macrocycle) $]$ (macrocycle $=[9] \mathrm{aneOS}_{2}$, [15] $\mathrm{aneO}_{3} \mathrm{~S}_{2}$, [18]aneO $\mathrm{O}_{3} \mathrm{~S}_{3}$ ) have also been described. Analysis of the ligand field spectra suggest 
coordination through sulfur (where possible) is preferred to coordination via oxygen, ascribed to ring strain effects as discussed above for the vanadium analogues. ${ }^{69}$ Small ring $\mathrm{Se}_{3}-$ and $\mathrm{Se}_{2} \mathrm{~N}$-donor macrocycle complexes $\left[\mathrm{CrCl}_{3}(\right.$ macrocycle $\left.)\right]$ and $\left[\mathrm{CrX}_{2}\left([16] \mathrm{aneSe}_{4}\right)\right]\left[\mathrm{PF}_{6}\right](\mathrm{X}=\mathrm{Cl}, \mathrm{Br})$ have been prepared, and analysis of their ligand field spectra suggest that the selenoethers are weaker donors than the thioether analogues as expected. ${ }^{86,89}$

Homogeneous olefin oligomerisation, especially selective trimerisation of ethene to produce 1-hexene, catalysed by chromium complexes containing tridentate SNS-donor ligands, $\mathrm{NH}\left\{\left(\mathrm{CH}_{2}\right)_{2} \mathrm{SR}\right\}_{2}(\mathrm{R}=\mathrm{Ph}$, $\mathrm{Cy}, n-\mathrm{C}_{10} \mathrm{H}_{21}$, etc.), and activated with organoaluminium reagents, has attracted considerable recent research effort. ${ }^{90-93}$ Although some of the mechanistic details remain elusive, and determination of the oxidation states involved in the cycle has proved challenging, the synthesis and structures of the precatalyst complexes, which have mer-octahedral $\left[\mathrm{CrCl}_{3}\left(\mathrm{NH}\left\{\left(\mathrm{CH}_{2}\right)_{2} \mathrm{SR}\right\}_{2}\right)\right]$ coordination, have been established. The presence of the soft S-donor functions in these systems has a significant influence on the selectivity of the catalytic process.

\subsection{Molybdenum and tungsten}

There seem to be no well-characterised thioether or selenoether complexes of the hexahalides of molybdenum or tungsten. Early studies reported the synthesis of $\left[\mathrm{WF}_{6} \mathrm{~L}_{2}\right]\left(\mathrm{L}=\mathrm{Et}_{2} \mathrm{~S}, \mathrm{Et}_{2} \mathrm{Se}\right)$ characterised by microanalysis and ${ }^{19} \mathrm{~F}$ NMR spectroscopy. ${ }^{94}$ In the light of recent X-ray structural authentication of $\left[\mathrm{WF}_{6}\left(\mathrm{PR}_{3}\right)\right]\left(\mathrm{R}_{3}=\mathrm{Me}_{3}, \mathrm{Me}_{2} \mathrm{Ph}\right){ }^{95}$ the formation of group 16 analogues seems reasonable, but re-examination is required to provide confirmation of their identities. Similarly, early studies of the reaction of $\mathrm{R}_{2} \mathrm{~S}\left(\mathrm{R}=\mathrm{Me}, \mathrm{Et}\right.$, $\left.{ }^{\mathrm{i}} \mathrm{Pr}\right)$, tht or $\mathrm{MeS}\left(\mathrm{CH}_{2}\right)_{2} \mathrm{SMe}$ with $\mathrm{WCl}_{6}$ in $\mathrm{CCl}_{4}$ solution, reported the formation of $\mathrm{W}(\mathrm{VI})$ complexes, including $\left[\mathrm{WCl}_{6}(\mathrm{tht})_{2}\right], \quad\left[\mathrm{WCl}_{6}\left(\mathrm{Me}_{2} \mathrm{~S}\right)\right]$ and $\left[\mathrm{WCl}_{6}\left\{\mathrm{MeS}\left(\mathrm{CH}_{2}\right)_{2} \mathrm{SMe}\right\}\right]$, whilst under other conditions or in other solvents, W(V) or W(IV) complexes, salts $\left[\mathrm{R}_{3} \mathrm{~S}\right]_{2}\left[\mathrm{WCl}_{6}\right]$, and various "non-stoichiometric" materials were obtained. ${ }^{96,97}$ Whilst the authenticity of the W(IV) complex, $\left[\mathrm{WCl}_{4}\left(\mathrm{Et}_{2} \mathrm{~S}\right)_{2}\right]$ (and of $\left[\mathrm{MoCl}_{4}\left(\mathrm{Et}_{2} \mathrm{~S}\right)_{2}\right]$ ), has been confirmed by X-ray crystallography and detailed magnetic studies, ${ }^{98,99}$ there seem to be no crystallographic studies of thioether complexes with $\mathrm{WCl}_{5}$ or $\mathrm{WCl}_{6}$, and this complicated chemistry merits reinvestigation using the more powerful suite of characterisation techniques available in the modern research laboratory. The chalcogenoethers $\mathrm{Me}_{2} \mathrm{~S}, \mathrm{MeS}\left(\mathrm{CH}_{2}\right)_{2} \mathrm{SMe}$ and $\mathrm{MeSe}\left(\mathrm{CH}_{2}\right)_{2} \mathrm{SeMe}$ failed to displace $\mathrm{MeCN}$ from $\left[\mathrm{WOF}_{4}(\mathrm{MeCN})\right]$ in $\mathrm{CH}_{2} \mathrm{Cl}_{2}$, and the diselenoether reduced the tungsten slowly on standing. ${ }^{100}$

Complex formation by the dioxide dichlorides, $\mathrm{MO}_{2} \mathrm{X}_{2}(\mathrm{M}=\mathrm{Mo}$ or $\mathrm{W} ; \mathrm{X}=\mathrm{Cl}$ or $\mathrm{Br})$, is better established. The direct reaction of $\mathrm{MoO}_{2} \mathrm{Cl}_{2}$ in anhydrous $\mathrm{CH}_{2} \mathrm{Cl}_{2}$ solution with $\mathrm{RS}\left(\mathrm{CH}_{2}\right)_{2} \mathrm{SR}(\mathrm{R}=\mathrm{Me}$, Et, ${ }^{\mathrm{i}} \mathrm{Pr}$ ) or 1,4-dithiane, gave yellow $\left[\mathrm{MoO}_{2} \mathrm{Cl}_{2}\right.$ (dithioether) $] .{ }^{101,102}$ The complexes, which are highly moisture sensitive (immediately turning blue in air), were fully characterised, including by IR, ${ }^{1} \mathrm{H}$ and

${ }^{95} \mathrm{Mo}$ NMR spectroscopy. ${ }^{101}$ The X-ray crystal structure of $\left[\mathrm{MoO}_{2} \mathrm{Cl}_{2}\left\{\mathrm{MeS}\left(\mathrm{CH}_{2}\right)_{2} \mathrm{SMe}\right\}\right]$ is shown in Fig. 44 and the IR spectra confirm that this geometry, with mutually cis- $\mathrm{MoO}_{2}$ groups and trans 
chlorides, is present in all of the complexes. The structural parameters are indicative of some $\mathrm{S} \rightarrow \mathrm{Mo}$ $\pi$-donation.

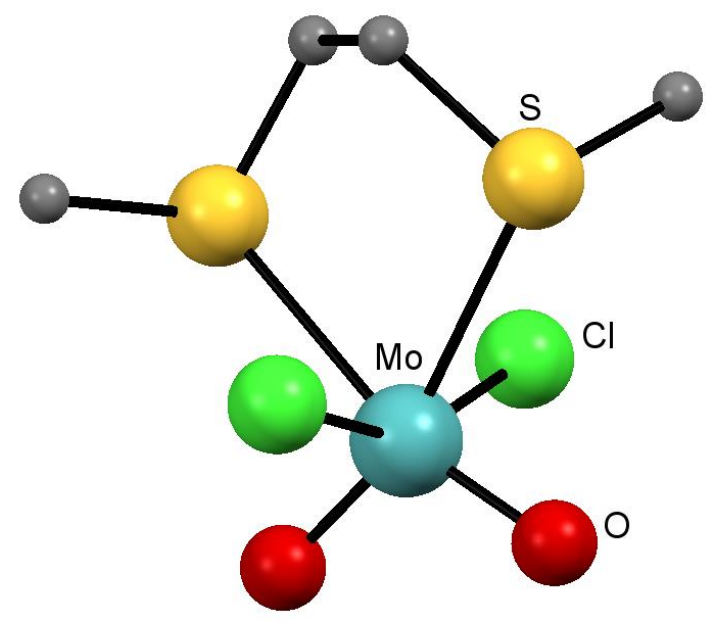

Figure 44. The structure of $\left[\mathrm{MoO}_{2} \mathrm{Cl}_{2}\left\{\mathrm{MeS}\left(\mathrm{CH}_{2}\right)_{2} \mathrm{SMe}\right\}\right]$, redrawn from Reference 101.

The analogous, but even less stable, $\left[\mathrm{MoO}_{2} \mathrm{Br}_{2}\right.$ (dithioether)], were also isolated using a similar method. ${ }^{101}$ The xylyl-linked dithioether, $o-\mathrm{C}_{6} \mathrm{H}_{4}\left(\mathrm{CH}_{2} \mathrm{SMe}\right)_{2}$, complexes with $\mathrm{MoO}_{2} \mathrm{Cl}_{2}$ to produce the dimeric $\left[\mathrm{Mo}_{2} \mathrm{O}_{4} \mathrm{Cl}_{4}\left\{\mu-o-\mathrm{C}_{6} \mathrm{H}_{4}\left(\mathrm{CH}_{2} \mathrm{SMe}\right)_{2}\right\}_{2}\right]$ (Fig. 45), although the S-donor atoms are now trans $\mathrm{O} / \mathrm{Cl}$, rather than trans $\mathrm{O} / \mathrm{O}$ and this results in significant differences in the bond length distribution at the Mo centre. ${ }^{102}$

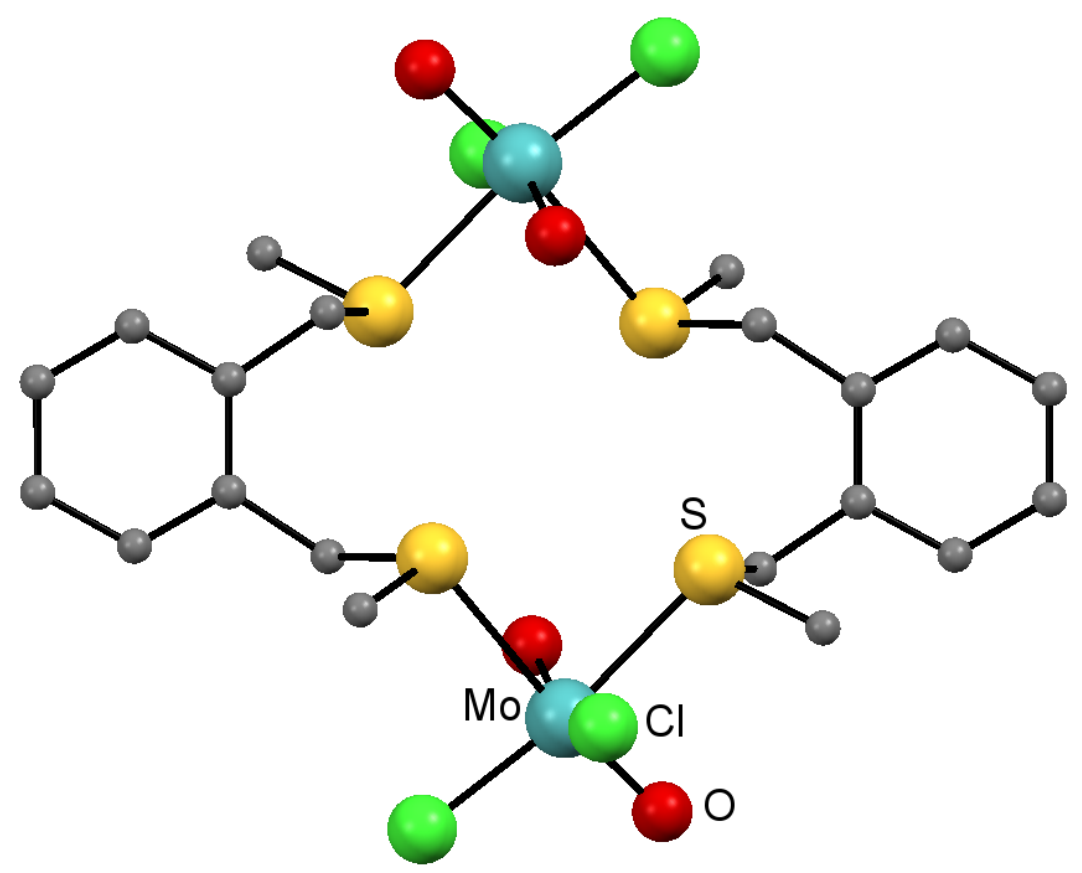

Figure 45. The structure of $\left[\mathrm{Mo}_{2} \mathrm{O}_{4} \mathrm{Cl}_{4}\left\{\mu-o-\mathrm{C}_{6} \mathrm{H}_{4}\left(\mathrm{CH}_{2} \mathrm{SMe}\right)_{2}\right\}_{2}\right]$, redrawn from Reference 102 .

The first diselenoether example, $\left[\mathrm{MoO}_{2} \mathrm{Cl}_{2}\left\{\mathrm{MeSe}\left(\mathrm{CH}_{2}\right)_{2} \mathrm{SeMe}\right\}\right]$, was also prepared, but is extremely unstable, decomposing even in the solid state - turning blue-green due to redox chemistry. The more strongly polymerised $\mathrm{WO}_{2} \mathrm{Cl}_{2}$ does not offer a satisfactory entry into the corresponding tungsten complexes. However, reaction of $\mathrm{WX}_{6}(\mathrm{X}=\mathrm{Cl}$ or $\mathrm{Br})$ or $\mathrm{WOCl}_{4}$ with $\left(\mathrm{Me}_{3} \mathrm{Si}\right)_{2} \mathrm{O}$ and the appropriate 
ligand in rigorously anhydrous $\mathrm{MeCN} / \mathrm{CH}_{2} \mathrm{Cl}_{2}$ solution, gave extremely moisture sensitive yellow or orange complexes, $\left[\mathrm{WO}_{2} \mathrm{X}_{2}\right.$ (dithioether) $]$ (dithioether $=\mathrm{MeS}\left(\mathrm{CH}_{2}\right)_{2} \mathrm{SMe},{ }^{\mathrm{i}} \mathrm{PrS}\left(\mathrm{CH}_{2}\right)_{2} \mathrm{~S}$ Pr or dithiane), and the X-ray crystal structure of $\left[\mathrm{WO}_{2} \mathrm{Cl}_{2}\left\{{ }^{\mathrm{i}} \mathrm{PrS}\left(\mathrm{CH}_{2}\right)_{2} \mathrm{~S} \mathrm{~S} \operatorname{Pr}\right\}\right]$ confirmed the same geometric arrangement as found in the molybdenum complexes. ${ }^{102,103}$ The heterocrown complex $\left[\mathrm{MoO}_{2} \mathrm{Cl}_{2}\left(\kappa^{2}-\right.\right.$ [15] ane $\mathrm{O}_{3} \mathrm{~S}_{2}$ ] was also obtained and the ${ }^{1} \mathrm{H}$ and ${ }^{95} \mathrm{Mo} \mathrm{NMR}$ spectra show the [15]aneO $\mathrm{O}_{3} \mathrm{~S}_{2}$ coordinated via the $\mathrm{S}$ rather than $\mathrm{O}$, similar to the behaviour of this ligand in the $\mathrm{Cr}$ and $\mathrm{V}$ systems described above. ${ }^{102}$ The $\left[\mathrm{MoO}_{2} \mathrm{Cl}_{2}\left([\mathrm{n}] \mathrm{aneS}_{4}\right)\right]\left([\mathrm{n}] \mathrm{aneS}_{4}=[12] \mathrm{aneS}_{4}\right.$ or [14]aneS $\left.\mathrm{S}_{4}\right)$ proved to be too poorly soluble for NMR measurements, although the IR spectra confirmed cis $-\mathrm{MoO}_{2}$ and trans $-\mathrm{MoCl}_{2}$ units. ${ }^{102}$

The chemistry of lower oxidation states of Mo and W with thioether ligands is extensive. ${ }^{13}$

\section{Summary and outlook}

The compounds described in this article reveal that, perhaps contrary to original expectations, there is a very extensive chemistry of ligands containing neutral $\mathrm{S}$ and Se donor groups bound to hard, early metals, with the unprecedented complexes in Groups 1-3 and the $4 \mathrm{f}$ block mostly prepared in the last few years. Some examples from Groups 4-6 metals in their higher oxidation states have been known for many years, but detailed exploration of the complex chemistry is also relatively recent. The paucity of examples with $5 \mathrm{f}$ metals would seem to reflect the lack of availability of the actinide precursors (Th and $\mathrm{U}$ excepted) to most researchers, and it seems likely that many more examples would be accessible, including with Th(IV) and U(III-VI), and, for those workers with access to the metal reagents, a range of $\mathrm{Np}$ and $\mathrm{Pu}$ complexes.

The successful syntheses of these chalcogenoether complexes requires careful design of the reaction conditions, including anhydrous systems, use of weak donor solvents and, particularly for the s-block species, the avoidance of strongly coordinating anions. Chlorocarbons are the solvents of choice in most syntheses, although anhydrous $\mathrm{MeCN}$ may be suitable in some cases, but ethers such as thf should be avoided with these oxophilic Lewis acids. Anhydrous conditions are a key prerequisite, since water is a good ligand to these hard metals, although even here there were surprises, for example, the displacement of the iodide rather than the $\mathrm{S}$ or Se donor from $\left[\mathrm{MI}_{2}\right.$ (heterocrown)] by trace water, forming $\left[\mathrm{M}\left(\mathrm{OH}_{2}\right)_{\mathrm{x}}(\right.$ heterocrown $\left.)\right] \mathrm{I}_{2}(\mathrm{M}=\mathrm{Ca}$ or $\mathrm{Sr})$. The use of the large, very weakly coordinating $\left[\mathrm{BAr}^{\mathrm{F}}\right]^{-}$counter anions were crucial for the isolation of many complexes from Groups 1 and 2, since from these labile systems, small anions are likely to cause preferential crystallisation of the ligand-free metal salt (a result of their high lattice energies). A further problem, particularly with the $\mathrm{f}$ - and d-block fluoride complexes, is that the metal may prefer to polymerise via $\mathrm{M}-\mathrm{F}-\mathrm{M}$ bridges rather than bind to soft neutral ligands; this accounts for the absence of thio- or seleno-ether complexes of $\mathrm{ZrF}_{4}, \mathrm{TiF}_{4}$ etc. ${ }^{104}$ Halide-bridging is much less of a problem with $\mathrm{Cl}, \mathrm{Br}$ or $\mathrm{I}$, since these bridges are much weaker. 
In general, the complexes described in this Perspective have limited stability, and in addition to the often challenging syntheses, detailed characterisation also places significant demands on the experimentalist. The ability to collect X-ray crystallographic data rapidly and on small crystals at low temperatures, has been key to the successful structural characterisation of such sensitive materials. The developments in diffractometer hardware and computing power of the last 20 years has made such experiments more routine, although transfer and mounting of the crystals is still challenging. Similarly, the developments in solution multinuclear NMR spectroscopy following the introduction of FT NMR instrumentation, has made exploration of the speciation, and sometimes solution dynamics of these sensitive compounds possible, using a variety of nuclei (Table 1). There has been surprisingly little NMR work in the solid state on complexes in this area, but it is likely that this will change over the next few years. In parallel with the spectroscopic and structural developments, the advances in computational chemistry, especially DFT calculations, has provided insight into the metal-ligand interactions in novel systems, e.g. the alkali metal complexes of [24]ane $\mathrm{S}_{8}$ and heterocrowns such as $[18] \mathrm{aneO}_{4} \mathrm{~S}_{2}{ }^{16,17}$

To isolate the labile Group 1 and 2 complexes, heterocrown ethers, especially the hexadentate 18membered rings, have proved particularly successful, but it should be clearly noted that coordination of the $\mathrm{S} / \mathrm{Se}$ to the metal is not an inevitable consequence of incorporation of the donor into the macrocycle, since examples with less than all six donors coordinated are known (even for 18-crown6). The currently unique homoleptic $\left[\mathrm{Na}\left([24] \mathrm{aneS} \mathrm{S}_{8}\right)\right]^{+}$cation $(\mathrm{Li}$ or $\mathrm{K}$ analogues have not been isolated), ${ }^{16}$ suggests that in the most extreme cases "everything" has to be right for successful isolation. In this case, the hole-size and pre-organisation of the macrocycle seems to be particularly suited to incorporation of $\mathrm{Na}^{+}$. Thus, homoleptic thia-macrocycle complexes of the other alkali metals may be accessible by judicious selection of macrocyclic ring size, with a conformationally preorganised cavity, possibly a different $[\mathrm{BAr}]^{-}$anion and/or solvent - only time and "trial and error" attempts will tell.

Taking an overview of this chemistry, it is clear that thioether sulfur donor ligands dominate the area, with a significant, but smaller, number of selenoether examples. Use of [18] $\mathrm{aneO}_{4} \mathrm{Se}_{2}$ has demonstrated that binding of the Se function to Groups 1-3 and $4 \mathrm{f}$ metals is possible. Whether complexes of homoleptic selenoethers or other $\mathrm{O} / \mathrm{Se}$ heterocrowns are isolable remains to be established. There are some limitations in the bi- or poly-dentate selenium ligands which can be made, ${ }^{3,4}$ mostly due to the tendency of $-\mathrm{SeCH}_{2} \mathrm{CH}_{2} \mathrm{Se}-$ or $-\mathrm{SeCH}=\mathrm{CHSe}-$ units to eliminate $\mathrm{CH}_{2}=\mathrm{CH}_{2}$ or $\mathrm{HC} \equiv \mathrm{CH}$, and none are commercially available.

Very few telluroether complexes with the early metals have been isolated - again, this probably reflects a lack of effort on one hand, and also the limited availability of chelating telluroether ligands. The heterocrown [18] $\mathrm{aneO}_{4} \mathrm{Te}_{2}$ is known, ${ }^{105}$ but is very prone to $\mathrm{C}-\mathrm{Te}$ bond cleavage. The ready cleavage of $\mathrm{C}-\mathrm{Te}$ bonds is also evident in the $\mathrm{Nb}$ and $\mathrm{Ta}$ chemistry, but again there are some surprising successes, most notably, the isolation of the eight-coordinate $\left[\mathrm{Nb}_{2} \mathrm{Cl}_{8}\left(\mathrm{Me}_{2} \mathrm{Te}\right)_{4}\right],{ }^{76}$ and the 
$\left[\mathrm{TaX}_{5}\left(\mathrm{Me}_{2} \mathrm{Te}\right)\right]$ series $(\mathrm{X}=\mathrm{F}, \mathrm{Cl}, \mathrm{Br}, \mathrm{I}){ }^{73}$ Telluroethers are also stronger reducing agents than the lighter analogues, and redox chemistry may be preferred over complexation for the higher oxidation state d-block ions. It is probable that a significant number of telluroether complexes of Groups 4-6 metals could be obtained, but very careful choice of metal complex, tellurium ligand architecture and control of the reaction conditions will be essential.

The complexes of the Group 1-3 metals currently known provide examples of these metal ions in unusual S- or Se-rich environments which, for metals such as $\mathrm{Na}, \mathrm{K}, \mathrm{Ca}$ and $\mathrm{Mg}$, may be of interest to biochemists. In the longer term, the Group 1 and 2 compounds could be platforms for the development of new organometallic chemistries. Catalytic applications of complexes of $\mathrm{Sc}, \mathrm{Cr}$ and $\mathrm{Mo}$, especially in olefin oligomerisation, have been discussed in the appropriate sections, and the $\mathrm{CrCl}_{3}$-SNS complexes remain the preferred precatalysts for selective ethene trimerisation to 1-hexene.

Use of metal selenoether complexes as single source low pressure chemical vapour deposition reagents (LPCVD) for metal diselenide films has been demonstrated for $\mathrm{Ti}$ and $\mathrm{Nb},{ }^{44,45,73}$ and this approach with the appropriately tailored complex should be extendable to $\mathrm{TaSe}_{2}, \mathrm{ZrSe}_{2}, \mathrm{VSe}_{2}$, etc. The technological need for thin films and selective deposition onto nano-patterned substrates of these key semiconducting chalcogenides is likely to stimulate more effort in this area. Metal thioether complexes have been less useful for this application to-date, probably because the $\mathrm{C}-\mathrm{S}$ bond is stronger than the $\mathrm{C}-\mathrm{Se}$, but some success has been achieved, ${ }^{73}$ and careful ligand design should lead to viable single source LPCVD reagents for $\mathrm{MS}_{2}$ systems. There is a complete absence of single source CVD reagents for d-block metal tellurides currently, but since $\mathrm{MTe}_{2}$ materials also have very interesting properties for future technological applications, the challenge to identify viable reagents remains. The fact that high quality films of $\mathrm{Ga}_{2} \mathrm{Te}_{3}$ and $\mathrm{Bi}_{2} \mathrm{Te}_{3}$ can be deposited via LPCVD from $\left[\mathrm{GaCl}_{3}\left(\mathrm{Te}^{\mathrm{n}} \mathrm{Bu}_{2}\right)_{3}\right]$ and $\left[\mathrm{BiCl}_{3}\left(\mathrm{Te}^{\mathrm{n}} \mathrm{Bu}_{2}\right)_{3}\right]$, respectively, ${ }^{106,107}$ strongly suggests that the key will lie in finding a complex with appropriate volatility, which decomposes cleanly at an accessible temperature, and the ideal characteristics should be achievable by an appropriate combination of ligand and metal source. Use of other deposition techniques, such as aerosol assisted CVD, may also be provide an entry to these materials, although the challenge to completely exclude oxygen and moisture from the solutions is significant, and incorporation of oxygen in the films is undesirable for most applications.

The new chemistry described in this Perspective demonstrates that an astonishing variety of hard metal-soft chalcogenoether species can be prepared and isolated, but much work in this area remains, with new examples to be explored. For example, beryllium complexes are very underdeveloped, avoided by many workers due to toxicity concerns, but there is also surprisingly little work on magnesium systems where those concerns do not apply. Lanthanide(III) halide complexes have been made, but very little is known about complexes of the divalent lanthanides; there are some heterocrown complexes of $\mathrm{Yb}(\mathrm{II}),{ }^{36}$ those with Eu, Sm and possibly Tm warrant investigation, as does the use of weakly coordinating anions ( $c f$. calcium systems). 
In the d-block, thioether and selenoether complexes of $\mathrm{Ti}$ (III) and $\mathrm{Zr}$ (III) merit detailed study. The chemistry of $\mathrm{Nb}(\mathrm{V})$ and $\mathrm{Nb}(\mathrm{IV})$ has generated many unusual and unpredictable compounds and studies of $\mathrm{Ta}(\mathrm{IV})$, along with a reinvestigation of the chemistries of $\mathrm{WCl}_{6}, \mathrm{WCl}_{5}$ and $\mathrm{MoCl}_{5}$, should be rewarding, not only in revealing new chemistry, but to provide new precursors for the appropriate metal-dichalcogenides. As indicated above, telluroether chemistry of almost all the metals awaits detailed study. The latter will not be easy, and very meticulous care over the reaction conditions and thorough characterisation of the complexes will be essential. The problems of identifying the products of $\mathrm{C}-\mathrm{E}$ bond fission and ligand rearrangement observed in $\mathrm{Nb}$, Ta and $\mathrm{Mo}^{10,76,80,81}$ systems are likely to be even more challenging in the telluroether chemistry.

\section{Acknowledgements}

Y.-P.C thanks the University of Southampton for support via a VC scholarship, and we thank the Cambridge Structural Database for access to the crystallographic files used to draw the figures. We also thank past and present members of our research groups for their contributions to the results coming from our laboratories.

\section{References}

1. S. G. Murray and F. R. Hartley, Chem. Rev., 1981, 81, 365.

2. H. J. Gysling in The chemistry of organic selenium and tellurium compounds, S. Patai and Z. Rappoport (Eds) 1986, 1, 679. Wiley NY.

3. E. G. Hope and W. Levason, Coord. Chem. Rev., 1993, 122, 109.

4. W. Levason, S. D. Orchard and G. Reid, Coord. Chem. Rev., 2002, 225, 159.

5. A. J. Blake and M. Schröder, Adv. Inorg. Chem., 1990, 35, 1.

6. S. R. Cooper, S. C. Rawle, Struct. Bonding (Berlin), 1990, 72, 1.

7. W. Levason and G. Reid, in Supramolecular chemistry: from molecules to nanomaterials, P. A. Gale and J. W. Steed (eds), 2012, 3, 785. Wiley, NY.

8. W. Levason and G. Reid, J. Chem. Soc., Dalton Trans., 2001, 1953.

9. W. Levason, G. Reid and W. Zhang, Dalton Trans., 2011, 40, 8491.

10. W. Levason and G. Reid, J. Chem. Res.(s), 2002, 467.

11. W. Levason and G. Reid, Handbook of Chalcogen Chemistry (F. Devillanova Eds), RSC. 2006, 81.

12. W. Levason and G. Reid. Comprehensive Coordination Chemistry II, J. A. McCleverty and T. J. Meyer (Eds) 2004, 1, 391 and 399, Elsevier, Oxford.

13. Comprehensive Coordination Chemistry II, J. A. McCleverty and T. J. Meyer (Eds), 2004, 4, Elsevier, Oxford.

14. M. M. Olmstead and P. P. Power, Organometallics, 1990, 9, 1720; M. M. Olmstead and P. P. Power, J. Amer. Chem. Soc., 1989, 111, 4135; M. M. Olmstead and P. P. Power, J. Amer. Chem. Soc., 1990, 112, 8008. 
15. H. K. Frensdorff, J. Amer. Chem. Soc., 1971, 93, 600; J. D. Lamb, R. M. Izatt, C. S. Swain and J. J. Christensen, J. Amer. Chem. Soc., 1980, 102, 475.

16. M. J. D. Champion, J. M. Dyke, W. Levason, M. E. Light, D. Pugh, H. Bhakoa, L. Rhyman, P. Ramasami and G. Reid, Inorg. Chem. 2015, 54, 2497.

17. M. J. D. Champion, W. Levason, D. Pugh and G. Reid, Dalton Trans., 2015, 44, 18748.

18. M. L. Campbell, N. K. Dalley and S. H. Simonsen, Acta Crystallogr. Sect. B, 1981, 37, 1747; M. L. Campbell, S. B. Larson and N. K. Dalley, Acta Crystallogr. Sect. B, 1981, 37, 1744; M. L. Campbell, S. B. Larson and N. K. Dalley, Acta Crystallogr. Sect. B, 1981, 37, 1741.

19. T. Röttgers and W. S. Sheldrick, J. Solid State Chem., 2000, 152, 271; T. Röttgers and W. S. Sheldrick, Z. Anorg. Allgem. Chem., 2001, 627, 1976; T. Röttgers and W. S. Sheldrick, Z. Anorg. Allgem. Chem., 2002, 628, 1305; T. Röttgers and W. S. Sheldrick, Z. Anorg. Allgem. Chem., 2003, 629, 1589.

20. H.-J. Drexler, H. Reinke and H.-J. Holdt, Z. Anorg. Allgem. Chem., 1998, 624, 1376.

21. M. Carravetta, M. Concistre, W. Levason, G. Reid and W. Zhang, Chem. Commun. 2015, 51, 9555.

22. K. J. Iversen, S. A. Couchman, D. J. Wilson and J. L. Dutton, Coord. Chem. Rev., 2015, $297-$ 298, 40; K. Dehnicke and B. Neumüller, Z. Anorg. Allgem. Chem., 2008, 634, 2703.

23. R. A. Kovar and G. L. Morgan, J. Amer. Chem. Soc., 1969, 91, 7269; G. E. Coates and M. Tranah, J. Chem. Soc. A, 1967, 236.

24. G. E. Coates and S. I. E. Green, J. Chem. Soc., 1962, 3340; K. N. Semenkova and N. Ya. Turova, Z. Neorg. Khim., 1963, 8, 2039; N. S. Sitdykova, N. Ya. Turova, K. N. Semenenko and A. V. Novoselova, Z. Neorg. Khim., 1961, 6, 2512.

25. D. Himmel and I. Krossing, Z. Anorg. Allgem. Chem., 2006, 632, 2012.

26. W. Levason, D. Pugh, J. M. Purkis and G. Reid, Dalton Trans., 2016, 45, 7900.

27. N. R. Streltsova, L. V. Ivakina, P. A. Storozhenko, B. M. Bulychev and V. K. Bel'ski, Dokl. Akad. Nauk. SSSR, 1986, 291, 1373.

28. I.-H. Park, P.-K. Park and S. S. Lee, Dalton Trans., 2010, 39, 9696.

29. P. Farina, W. Levason and G. Reid, Dalton Trans., 2013, 42, 89.

30. C. S. Tredget, F. Bonnet, A. R. Cowley and P. Mountford, Chem. Commun., 2005, 3301; C. S. Tredget, E. Clot and P. Mountford, Organometallics, 2008, 27, 3458.

31. M. D. Brown, W. Levason, D. C. Murray, M. C. Popham, G. Reid and M. Webster, Dalton Trans., 2003, 857.

32. M. J. D. Champion, P. Farina, W. Levason and G. Reid, Dalton Trans., 2013, 42, 13179.

33. S. A. Bartlett, G. Cibin, A. J. Dent, J. Evans, M. J. Hanton, G. Reid, R. P. Tooze and M. Tromp, Dalton Trans., 2013, 42, 2213.

34. L. Karmazin, M. Mazzanti and J. Pécaut, Chem. Commun., 2002, 664.

35. A. N. Kamenskaya, S. A. Kulyukhin, E. S. Levchenko and V. N. Kalinin, Koord. Khim., 1990, 16, 1141. 
36. P. N. Bartlett, M. J. D. Champion, M. E. Light, W. Levason, G. Reid and P. W. Richardson, Dalton Trans., 2015, 44, 2953.

37. M. Ephritikhine, Coord. Chem. Rev., 2016, 319, 35.

38. H. C. E. Mannerskantz, G. W. Parshall and G. Wilkinson, J. Chem. Soc., 1963, 3163.

39. A. Zalkin and J. G. Brennan, Acta Crystallogr. Sect. C, 1985, 41, 1295.

40. R. Shinomoto, A. Zalkin, N. M. Edelstein and D. Zhang, Inorg. Chem., 1987, 26, 2868.

41. T. Arliguie, L. Belkhiri, S.-E. Bouaoud, P. Thuéry, C. Villiers, A. Boucekkine and M. Ephritikhine, Inorg. Chem., 2009, 48, 221.

42. M. Schormann, Acta Crystallogr. Sect. E, 2003, 59, m674.

43. T. S. Lewkebandara, P. J. McKarns, B. S. Haggerty, G. P. A. Yap, A. L. Rheingold and C. H. Winter, Polyhedron, 1998, 17, 1.

44. P. J. McKarns, T. S. Lewkebandara, G. P. A. Yap, L. M. Liable-Sands, A. L. Rheingold and C. H. Winter, Inorg. Chem., 1998, 37, 418.

45. S. L. Benjamin, C. H. de Groot, C. Gurnani, A. L. Hector, R. Huang, K. Ignatyev, W. Levason, S. J. Pearce, F. Thomas and G. Reid, Chem. Mater., 2013, 25, 4719.

46. W. Levason, B. Patel, G. Reid, V.-A. Tolhurst and M. Webster, J. Chem. Soc., Dalton Trans., 2000, 3001 .

47. S. D. Reid, A. L. Hector, W. Levason, G. Reid, B. J. Waller and M. Webster, Dalton Trans., 2007, 4769.

48. R. Hart, W. Levason, B. Patel and G. Reid, Eur. J. Inorg. Chem., 2001, 2927.

49. M. Jura, W. Levason, E. Petts, G. Reid, M. Webster and W. Zhang, Dalton Trans., 2010, 39, 10264.

50. W. Levason, B.Patel and G. Reid, Inorg. Chim. Acta, 2004, 357, 2115.

51. G. R. Willey, J. Palin, M. T. Lakin and N. W. Alcock, Trans. Met. Chem., 1994, 19, 187.

52. W. Levason, M. C. Popham, G. Reid and M. Webster, Dalton Trans., 2003, 291.

53. P. J. Wilson, A. J. Blake, P. Mountford and M. Schröder, Chem. Commun., 1998, 1007; P. J. Wilson, A. J. Blake, P. Mountford and M. Schröder, Inorg. Chim. Acta, 2003, 345, 44.

54. R. N. Pandey, R. K. Singh and K. Shahi, Asian. J. Chem., 2011, 23, 2739.

55. R. Hart, W. Levason, B. Patel and G. Reid, J. Chem. Soc., Dalton Trans., 2002. 3153.

56. S. L. Benjamin, W. Levason, D. Pugh, G. Reid and W. Zhang, Dalton Trans., 2012, 41, 12548.

57. C. D. Beard, R. J. Barrie, J. Evans, W. Levason, G. Reid and M. D. Spicer, Eur. J. Inorg. Chem., 2006, 4391.

58. A. L. Hector, W. Levason, A. J. Middleton, G. Reid and M. Webster, Eur. J. Inorg. Chem., 2007,3655 .

59. M. F. Davis, W. Levason, J. Paterson, G. Reid and M. Webster, Eur. J. Inorg. Chem., 2008, 802. 
60. M. F. Davis, M. Jura, A. Leung, W. Levason, B. Littlefield, G. Reid and M. Webster, Dalton Trans., 2008, 6265.

61. A. L. Hector, M. Jura, W. Levason, S. D. Reid and G. Reid, New. J. Chem., 2009, 33, 641.

62. M. Matsuura, T. Fujihara and A. Nagasawa, Acta Crystallogr., Sect. E, 2013, 69, m209.

63. G. R. Willey, M. T. Lakin and N. W. Alcock, J. Chem. Soc., Chem. Commun., 1991, 1414.

64. M. C. Durrant, S. C. Davies, D. L. Hughes, C. Le Floc'h, R. L. Richards, J. R. Sanders, N. R. Champness, S. J. Pope and G. Reid, Inorg. Chim. Acta, 1996, 251, 13; S. C. Davies, M. C. Durrant, D. L. Hughes, C. Le Floc'h, S. J. A. Pope, G. Reid, R. L. Richards and J. R. Sanders, J. Chem. Soc., Dalton Trans., 1998, 2191.

65. U. Heinzel, A. Henke and R. Mattes, J. Chem. Soc., Dalton Trans., 1997, 501.

66. B. M. Gray, A. L. Hector, W. Levason, G. Reid, M. Webster, W. Zhang and M. Jura, Polyhedron, 2010, 29, 1630.

67. D. Rehder, H. Nekola, A. Behrens, S. P. Cramer and T. Funk, Z. Anorg. Allgem. Chem., 2013, 639, 1401.

68. G. J. Grant, K. E. Rogers, W. N. Stelzer and D. G. VanderVeer, Inorg. Chim. Acta, 1995, 234, 35 .

69. C. D. Beard, L. Carr, M. F. Davis, J. Evans, W. Levason, L. D. Norman, G. Reid and M. Webster, Eur. J. Inorg. Chem., 2006, 4399.

70. Lead references: H. Nekola, D. Wang, J. Gätjens, A. Behrens and D. Rehder, Inorg. Chem., 2002, 41, 2379; M. Farahbakhsh, H. Nikola, H. Scmidt and D. Rehder, Chem. Ber./Recueil, 1997, 130, 1129; D. Rehder, H. Nikola, A. Behrens, S. P. Cramer and T. Funk, Z. Anorg. Allg. Chem., 2013, 639, 1401.

71. M. Jura, W. Levason, R. Ratnani, G. Reid and M. Webster, Dalton Trans., 2010, 39, 883.

72. S. L. Benjamin, A. Hyslop, W. Levason and G. Reid, J. Fluorine Chem., 2012, 137, 77.

73. S. L. Benjamin, Y.-P. Chang, C. Gurnani, A. L. Hector, M. Huggon, W. Levason and G. Reid, Dalton Trans., 2014, 43, 16640.

74. F. Marchetti, G. Pampaloni and S. Zacchini, J. Fluorine Chem., 2010, 131, 21.

75. M. Jura, W. Levason, G. Reid and M. Webster, Dalton Trans., 2009, 7610.

76. Y.-P. Chang, W. Levason, M. E. Light and G. Reid, Dalton Trans., submitted.

77. S. L. Benjamin, A. Hyslop, W. Levason and M. Webster, Acta Crystallogr., Sect. C, 2011, 67, $\mathrm{m} 221$.

78. W. Levason, G. Reid, J. Trayer and W. Zhang, Dalton Trans. 2014, 43, 3649.

79. J. B. Hamilton and R. E. McCarley, Inorg. Chem., 1970, 9, 1333; J. B. Hamilton and R. E. McCarley, Inorg. Chem., 1970, 9, 1339.

80. S. L. Benjamin, Y.-P. Chang, M. Huggon, W. Levason and G. Reid, Polyhedron, 2015, 99, 230.

81. E. Babaian-Kilbala, F. A. Cotton and P. A. Kibala, Inorg. Chem., 1990, 29, 4002. 
82. Lead references: F. A. Cotton, X. Feng, P. Gütlich, T. Kohlhaas, J. Lu and M. Shang, Inorg. Chem., 1994, 33, 3055; M. Kakeya, T. Fujihara, T. Kasaya and A. Nakgasawa, Organometallics, 2006, 25, 4131.

83. M. Matsuura, T. Fujihara, M. Kakeya and T. Sugaya, J. Organometal. Chem., 2013, 745-746, 288.

84. W. Levason, G. Reid and W. Zhang, Z. Anorg. Allgem. Chem., 2014, 640, 35.

85. W.-H. Leung, M.-C. Wu, T. K. T. Wong and W.-T. Wong, Inorg. Chim. Acta, 2000, 304, 134.

86. W. Levason, G. Reid and S. M. Smith, Polyhedron, 1996, 16, 4253.

87. S. J. A. Pope, N. R. Champness and G. Reid, J. Chem. Soc., Dalton Trans., 1997, 1639.

88. N. R. Champness, S. R. Jacob, G. Reid and C. S. Frampton, Inorg. Chem., 1995, 34, 396.

89. W. Levason, J. M. Manning, G. Reid, M. Tuggey and M. Webster, Dalton Trans., 2009, 4569.

90. D. S. McGuinness, P. Wasserscheid, W. Keim, D. Morgan, J. T. Dixon, A. Bollmann, H. Maumela, F. Hess and U. Englert, J. Amer. Chem. Soc., 2003, 125, 5272.

91. C. Temple, A, Jabri, P. Crewdson, S. Gambarotta, I. Korobkov and R. Duchateau, Angew. Chem. Int. Ed., 2006, 45, 7050; C. N. Temple, S. Gambarotta, I, Korobkov and R. Duchateau, Organometallics, 2007, 26, 4598.

92. K. Albahily, S. Gambarotta and R. Duchateau, Organometallics, 2011, 30, 4655.

93. S. A. Bartlett, J. O. Moulin, M. Tromp, G. Reid, A. J. Dent, G. Cibin, D. S. McGuinness and J. Evans, ACS Catalysis, 2014, 4, 4201.

94. A. M. Noble and J.M. Winfield, Inorg. Nucl. Chem. Letts., 1968, 4, 339.

95. S. El-Kurdi, A.-A. Al-Terkawi, B. M. Schmidt, A. Dimitrov and K. Seppelt, Chem. Eur. J., 2010, 16, 595.

96. P. M. Boorman, M. Islip, M. M. Reimer and K. J. Reimer, J. Chem. Soc., Dalton Trans., 1972, 890.

97. P. M. Boorman, T. Chivers and K. N. Mahedev, Can. J. Chem., 1975, 53, 383.

98. P. Dierkes, G. Frenzen, S. Wocadlo, W. Massa, S. Berger, J. Peblers and K. Dehnicke, Z. Naturforsch. B, 1995, 50, 159.

99. M. A. S. King and R. E. McCarley, Inorg. Chem., 1973, 12, 1972.

100. W. Levason, G. Reid and W. Zhang, J. Fluorine Chem., 2016, 184, 50.

101. M. D. Brown, M. B. Hursthouse, W. Levason, R. Ratnani and G. Reid, Dalton Trans., 2004, 2487.

102. M. F. Davis, W. Levason, M. E. Light, R. Ratnani, G. Reid, K. Saraswat and M. Webster, Eur. J. Inorg. Chem., 2007, 1903.

103. X. Ma, K. Starke, C. Schulzke, H.-G. Schmidt and M. Noltemeyer, Eur. J. Inorg. Chem., 2006, 628 . 
104. S. L. Benjamin, W. Levason and G. Reid, Chem. Soc. Rev., 2013, 42, 1460.

105. M. J. Hesford, W. Levason , M .L. Matthews and G. Reid. Dalton Trans., 2003, 2852.

106. K. George, C. H. de Groot, C. Gurnani, A. L. Hector, R. Huang, M. Jura, W. Levason and G. Reid, Chem. Mater., 2013, 25, 1829.

107. S. L. Benjamin, C. H. de Groot, C. Gurnani, A. L. Hector, R. Huang, E. Koukharenko, W. Levason and G. Reid, J. Mater. Chem. A, 2014, 2, 4865. 